
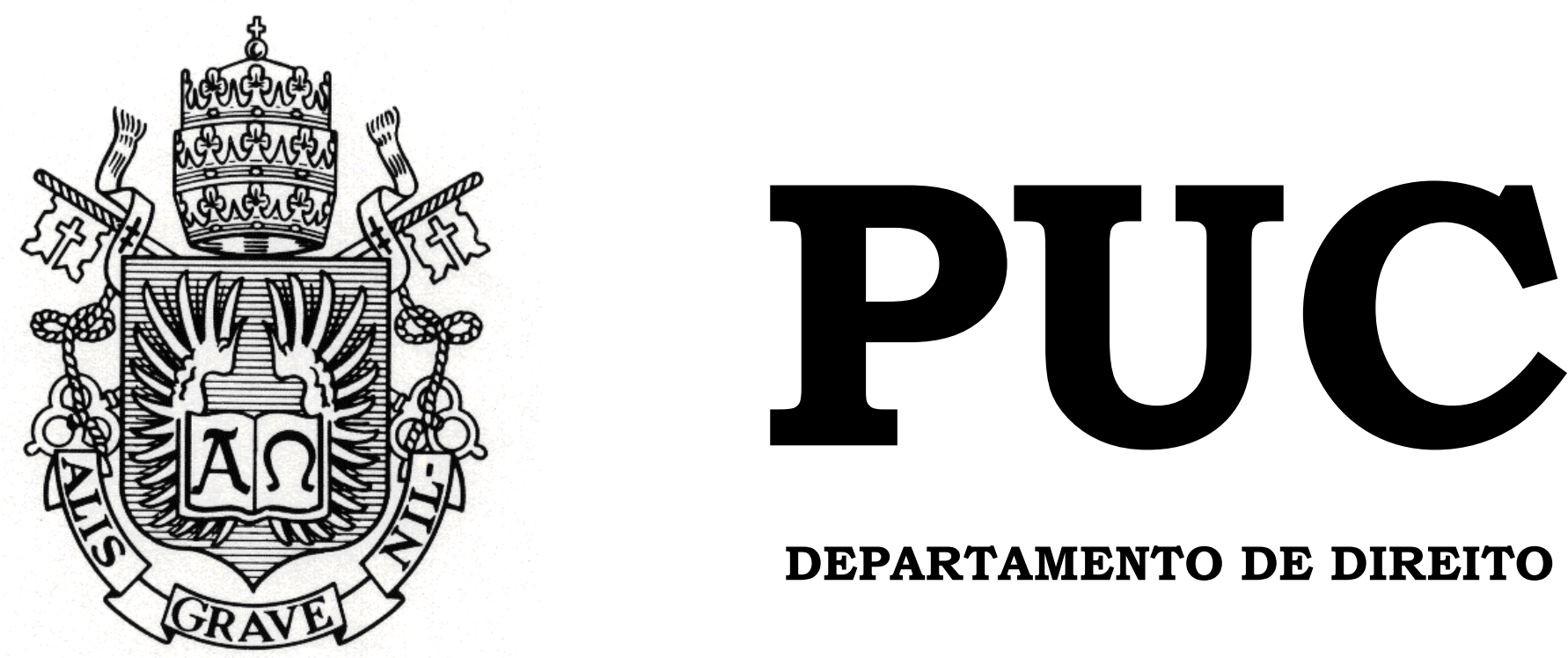

DEPARTAMENTO DE DIREITO

\title{
ESTUDO DO CASO DA VILA AUTODRÓMO- ANÁLISE DA JUSTIFICATIVA DO PODER PÚBLICO SOB ÓTICA DOS PRINCÍPIOS CONSTITUCIONAIS E DIREITO DE PERMANÊNCIA
}

por

REBECA SOUZA PETERLI DOS SANTOS

ORIENTADOR(A): ADRIANO PILATTI

2015.2

PONTIFÍCIA UNIVERSIDADE CATÓLICA DO RIO DE JANEIRO

RUA MARQUÊS DE SÃO VICENTE, 225 - CEP 22453-900

RIO DE JANEIRO - BRASIL 


\section{ESTUDO DO CASO DA VILA AUTODRÓMO- ANÁLISE DA JUSTIFICATIVA DO PODER PÚBLICO SOB ÓTICA DOS PRINCÍPIOS CONSTITUCIONAIS E DO DIREITO DE PERMANÊNCIA}

por

\section{REBECA SOUZA PERTERLI DOS SANTOS}

Monografia apresentada ao Departamento de Direito da Pontifícia Universidade Católica do Rio de Janeiro (PUC-Rio) para a obtenção do Título de Bacharel em Direito.

Orientador(a): Adriano Pilatti 


\section{Agradecimentos}

Agradeço a Deus por ter me concedido essa oportunidade, por ter me dado forças para prosseguir, estando ao meu lado, e, ainda por ter proporcionado meu encontro com pessoas maravilhosas, muitas das quais citadas nesses singelos agradecimentos.

Aos meus pais, Ronaldo e Creuza, e minhas irmãs, Raquel e Rute, sem os quais nada disso seria possível. Estiveram do meu lado em todos os momentos e sabem mais do que ninguém como fazer esse curso e trabalho foi tão difícil, mas nunca deixaram de acreditar em mim.

Ao meu avô Milton Santos, em memória. Amava o direito e sonhava em compartilhar esse momento comigo. Lembro-me das conversas em que me queixava cansaço e medo, mas ele sempre tinha uma palavra de ânimo arrebatador.

Ao Adailton Jesus da Silva, meu namorado, mas antes de tudo, meu melhor amigo, companheiro e a pessoa que sempre pude confiar. Acompanhou de perto minhas angústias, meus medos, minhas conquistas, meu amadurecimento, meu início, meu final e o início de um novo começo. Caminhamos juntos nessa estrada e espero que juntos possamos continuar. Sem ele a PUC seria sem cor para mim, sem sentido.

Às minhas amigas, Maria Carolina Cypriani e Rosa Jara, e especialmente à Rafaela Santos, uma pessoa de espírito elevado. Agradeço sua paciência para comigo, sua atenção, constante ajudas a mim e aos outros.

Ao professor Adriano Pilatti por ter me orientado na elaboração desse trabalho, pelas trocas e pela confiança depositada. Sou grata pela 
disponibilidade em me ajudar e por acreditar em mim, mesmo diante das minhas constantes dúvidas, angustias pessimismos, incertezas, desesperos e reiteradas mudanças de temas. Por fim, pelo espírito inquieto diante de tantas arbitrariedades perpetradas pelo poder público.

Ao professor Pedro Marcos Nunes Barbosa. Extremante solicito! Mostrou-se sempre disponível para ajudar os estudantes. Acompanhou-me desde o início da faculdade ( $2^{\circ}$ período) orientando-me e sempre me auxiliando, foi um grande mestre. Agradeço, especialmente, pela ajuda na elaboração desse trabalho, as leituras atentas e sua receptividade constante.

À professora Virginia Totti Guimarães pelas constantes críticas e sugestões. Por toda atenção que me ofereceu mesmo diante de seus compromissos. Sem ela esse trabalho não seria possível, literalmente, pois além das críticas e sugestões, ela me ajudou a perceber como estava "crua" em relação ao outro tema que seria trabalhado.

Aos professores Leonardo Chaves, Rosângela Cavallazi e Marianna Montebello Willema por terem disponibilizado seus valiosos tempo para atender-me, indicando bibliografia e disponibilizando material que foram muito uteis na execução do presente trabalho.

Aos funcionários do departamento de direito da PUC-Rio, em especial Igor Martins, Igor Correia, Gilmar Villas Boas e Henry Douglas, em memória, por sempre estarem dispostos a me auxiliar resolvendo problemas e prestando informações sempre de forma tão cordial.

À defensora pública titular do Núcleo de Terras e Habitação, Maria de Lúcia Pontes, que diante das adversidades mantem-se perseverante na luta pela justiça e igualdade social. Também a agradeço por todo apoio que 
me concedeu durante os anos em que estagiei no NUTH. És inspiração para mim e para tantos outros e outras.

Aos estagiários e servidores do NUTH, em especial Yasmim Mouffron (estagiária) e Luiz Amaral (servidor público) que sempre me apoiaram diante das minhas angústias e ajudaram-me na separação dos documentos oficiais necessários para elaboração do presente trabalho.

Aos moradores da Vila Autódromo que se mantém resistentes na luta pelo direito à moradia diante das injustiças sociais. Em especial agradeço à Penha e Heloísa Helena que disponibilizaram seu tempo para contar-me sobre as injustiças praticadas contra a Vila Autódromo. 
"O totalitarismo moderno pode ser definido como a instauração, por meio do estado de exceção, de uma guerra civil legal que permite a eliminação física não dos adversários políticos, mas também de categorias inteiras de cidadãos que, por qualquer razão, pareçam não integráveis ao sistema político" (Giorgio Agambem; Estado de exceção. São Paulo, Boitempo,2004, p. 13)

[...]a cidade grande é o espaço onde os fracos podem subsistir." (Milton Santos, A natureza do Espaço: Técnica e Tempo, Razão e Emoção. São Paulo, Editora da Universidade de São Paulo,2009, p.322)

A cidade, em silêncio, com grito ensurdecedor clama por socorro Suplica pela proteção do seu povo

Que é massacrado pelo Estado Que pouco se importa com seu estado.

Arbítrio e ilegal, o Estado faz do seu povo pouco caso. do céu, cidade não suporta mais as lágrimas da Favela. não aguenta mais tanto descaso

Cidade clama! Ainda mantém acessa fé e esperança.

Vila autódromo vive, resiste Rio de Janeiro revive!

Novembro de 2015 A autora 


\section{Prefácio}

Este é um trabalho intrinsicamente ligado a minha trajetória acadêmica. Estagiei no Núcleo de Terras e Habitação da Defensoria Pública do Estado do Rio de Janeiro (NUTH) desde janeiro de 2012 até o fim da minha graduação, em 2015. Apesar de inicialmente atuar voluntariamente e não comparecer todos os dias úteis ao NUTH, desenvolvi uma paixão pelo trabalho realizado pelos defensores, em especial a dr. ${ }^{a}$ Maria Lúcia de Pontes, minha mentora desde então.

As arbitrariedades cometidas pelo Poder Público em relação aos moradores, nossos assistidos, e os problemas institucionais não desanimaram a defensora Maria Lúcia que seguia/segue firme na luta pelo direito à moradia e pelo empoderamento dos moradores, conscientizando-os da titularidade do seu poder e para o fato de que não podem ficar inertes em relação as ilegalidades e arbitrariedades cometida pelos nossos gestores, sendo necessária, portanto, a resistência.

Toda a experiência e vivência no Núcleo de Terras aliada as pesquisas que desenvolvi no Programa de Iniciação Científica da PUC/RJ orientada pelo professor Augusto Werneck e os ensinamentos dos professores Ricardo Pereira Lira e Alexandre Mendes fizeram-me refletir e optar pelo estudo sobre as justificativas apresentadas pelo Poder Público Municipal para remover a comunidade Vila Autódromo sob ótica dos princípios constitucionais e do direito de permanência dos mesmos. 


\section{Resumo}

As práticas remocionistas são traços marcantes nas políticas urbanas brasileiras, especialmente cariocas. Tais praticas são observadas atualmente no contexto dos megaeventos, sobretudo na cidade do Rio de Janeiro, sede dos Jogos Olímpicos de 2016. Nesse sentido, o Poder Público Municipal apresenta diferentes justificativas visando remoção das favelas cariocas, muitas das quais representam argumentos falaciosos, que escondem objetivo de mercantilização e elitização do espaço urbano. A Vila Autódromo, assentamento localizado próximo a Barra da Tijuca, é alvo das atuais políticas remocionistas. Visando à remoção da referida comunidade a municipalidade apresentou diferentes justificativas ao longo do tempo. Desse modo, o presente trabalho objetiva analisar as justificativas apresentas pelo Poder Público carioca sob ótica dos princípios constitucionais, mais especificamente, da legalidade, da publicidade, transparência e moralidade administrativa e do direito de permanência. Espera-se que esta monografia contribua para o conhecimento de um dos problemas que ocorrem na cidade do Rio de Janeiro, mais especificamente no ato de remoção da Vila Autódromo, e para reflexão crítica dos atos de remoção das favelas cariocas e, ainda, sinalizar a necessidade da Administração Pública observar dos preceitos teóricos- normativos aplicáveis ao caso a fim de garantir a justiça social, efetividade dos direitos fundamentais e da democracia.

\section{Palavras-Chaves}

Remoção; Direito de permanência; Interesse Público; Fundamentação; Princípios Constitucionais; Mercantilização; Elitização; Rio de Janeiro; Vila Autódromo. 


\section{Sumário}

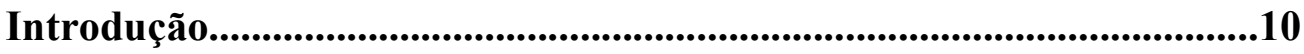

Capítulo 1. Princípios vinculantes da atuação da Administração Pública e direitos fundamentais - Premissas teórico-normativas em caso de remoções de Favelas...........................................................18

1.1. Princípios vinculantes da Administração Pública.................20

1.1.1 Legalidade, impessoalidade, moralidade e publicidade....20

1.1.2 Pressupostos do Ato Administrativo: Motivo.................25

1.1.3 Supremacia do interesse público.................................29

1.2 Direito a não remoção: Limitação à atuação administrativa ......36

1.2.1 Princípio da confiança: Amparo ao direito a não remoção das Comunidades..........................................................37

1.2.2 Função social da cidade, da posse e direito à cidade...42

1.2.3 Direito à moradia.

Capítulo 2. "Cidade de negócios", megaeventos e política remocionista

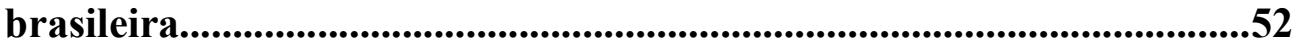

2.1. Cidade negócio e políticas segregacionistas................52

2.2 Política de elitização e mercantilização na cidade do Rio

de Janeiro no contexto dos megaeventos................................................60 
Capítulo 3. Análise da justificativa do Poder público sob a ótica dos princípios Constitucionais e do Direito de Permanência........................65

3.1. Vila Autódromo: formação, titulação, remoção........................65

3.2. Vila Autódromo: Direito de permanência................................69

3.3 Justificativas apresentadas pela Prefeitura para remoção da Vila Autódromo. .71

3.4 Análise da fundamentação da remoção sob ótica da legalidade (juridicidade administrativa) publicidade e moralidade pública. .75

3.5 Motivos para remoção da Vila Autódromo. .80

3.6 Remoção da Vila Autódromo sob justificativa de Interesse

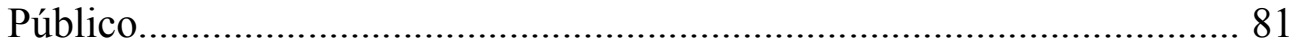

3.7 Vila Autódromo e o projeto "Cidade negócios". .84

Conclusão

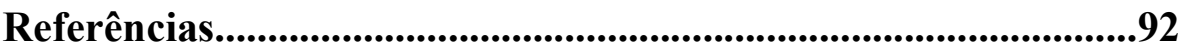

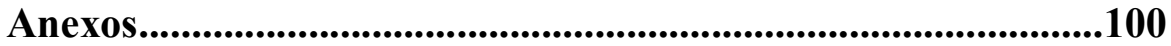




\section{Introdução}

A Administração Pública pratica arbitrariedades para remover os moradores das favelas do Rio de Janeiro. Há casos, tais como ocorridos nas comunidades Vila Harmonia, Recreio II e Restinga que casas erguidas há décadas foram demolidas pela Municipalidade sem pagamento prévio de compensação. Em outras situações similares o Poder Público carioca apenas pagou um valor irrisório a título de aluguel social cuja prestação foi limitada por um curto período de tempo. ${ }^{1}$

Ressalta-se, ainda, que a Prefeitura do Rio de Janeiro utiliza o programa "Minha Casa Minha Vida" (lei n 11.977, de 7 de julho de 2009) para incentivar a política de remoções, apresentado o programa como melhor opção de moradia. Fato constatado na comunidade Indiana e Vila Autódromo, por exemplo ${ }^{2}$. Além disso, casas são demolidas sem autorização judicial, a título exemplificativo cita-se a liminar proferida no processo 0075959-18.2013.19.0001 que vedava as demolições das casas situadas na comunidade Vila Autódromo desrespeitada pelo Município do Rio de Janeiro.

Outro exemplo de ilegalidade é o fato de que municipalidade pressiona os moradores, muitas vezes com utilização da violência, para que os mesmos saiam de suas moradias. Essa pressão pode ser observada nos atos e nas negociações que a municipalidade realizou com moradores da Vila Autódromo. ${ }^{3}$

\footnotetext{
${ }^{1}$ CHAVES, Leonardo em entrevista a Eduardo Sá. Disponível em: $<$ http://www.barracoadentro.com/\%E2\%80\%9Cnao-esta-havendo-um-processo-de-desapropriacaoo-que-esta-havendo-e-um-processo-de-espoliacao\%E2\%80\%9D/>.Acesso em 19/09/2015.

${ }^{2}$ PONTES. Maria Lúcia de. Comunidade Indiana - Programa Minha Casa Minha Vida: Incentivo à política habitacional ou mecanismo de estímulo a remoção na cidade do Rio de Janeiro. Pg. 83 In: Os Conflitos fundiários no Brasil : estratégias de luta contra os despejos e empoderamento a partir da teoria crítica de direitos humanos . Organizadores: Cristiano Muller, Karla Fabrícia Moroso dos Santos Azevedo.Porto alegre: CDES Direitos Humanos,2014.

${ }^{3}$ Relatos dos moradores assistidos pelo Núcleo de Terras e habitação da Defensoria Pública do Estado do Rio de Janeiro.
} 
Um dos argumentos utilizados pela Prefeitura do Rio para demolir casas localizadas em várias favelas, e, portanto, remover vários moradores é de que as moradias estão localizadas em "área de risco". Entretanto este argumento é utilizado, em regra, sem prévio estudo técnico que comprove a situação de risco, como é o caso da comunidade Indiana, localizada na zona norte do Rio de Janeiro entre as ruas Paul Underberg, Ary Kemer e São Miguel.

Em várias situações o Município carioca objetiva remover comunidades sem fundamento prévio e em outras situações são apresentadas justificativas infundadas, muitas vezes rechaçadas por avaliações técnicas, que demostram, inclusive, a inexistência de projeto para área objeto de remoção. Destarte, tal ato administrativo revela-se desprovido de finalidade, um dos requisitos essenciais do ato administrativo.

A ausência de finalidade para o ato administrativo ou apresentação de finalidade não idônea constitui uso indevido da regra de competência administrativa, expressando assim, violação ao princípio da impessoalidade e da moralidade administrativa, lesão ao erário, uma vez que é necessário reassentamento ou indenização aos moradores das comunidades removidas, e, assim, mancham o princípio republicano.

As remoções das comunidades per ser, sem que sejam apresentados os motivos para o ato ou que sejam motivos falaciosos, representam atuação arbitrária da Administração Pública. Todavia a Administração Pública brasileira não pode atuar arbitrariamente, pois deve obediência aos princípios constitucionais de legalidade, impessoalidade, moralidade, publicidade e eficiência (art. 37 da CRFB). Além desses princípios expressamente estabelecidos é necessária a observância de outros previstos em leis esparsas e também os implicitamente considerados.

A Constituição Federal de 1988, a chamada Constituição "cidadã", estabelece a dignidade humana como fundamento do Estado Democrático de Direito (art. 1, inciso III), consagrando como seu objetivo precípuo a 
construção de uma sociedade livre, justa e solidária (art. 2, inciso I), bem como propugna pela redução das desigualdades sociais e regionais. Não obstante sejam esses os fundamentos e objetivos do Estado Democrático de Direito brasileiro, o Poder Público carioca tem colocado os interesses econômicos e mercantilistas acima das necessidades e, sobretudo dos direitos de grupos formadores da sociedade, violando, assim, a legalidade e moralidade pública.

Esse fato é constatado em casos de remoções forçadas, o qual a Administração Pública ignora a legislação constitucional e infraconstitucional existente e decreta remoções sem fundamentos jurídicos e fáticos sólidos. A motivação para muitos desses atos administrativos é "o risco de vida" ou "interesse público". Justificativas que muitas vezes escondem um projeto de mercantilização e elitização do espaço urbano.

Além da contestável justificativa "pública", os processos executórios de remoções também são alvo de críticas de especialistas e pesquisadores, pois tais atos têm violado a legislação nacional e internacional vigente e gerado graves violações de direitos humanos. Raquel Rolnik, relatora especial da ONU sobre moradia adequada entre 2007 e 2014, demostra preocupação com as violações de direitos humanos para implantação dos megaeventos. ${ }^{4}$ Segundo tal especialista, em outras experiências, resultaram em operações de 'limpeza' contra a população sem-teto'.

Em 2012, o Comitê Popular da Copa e das Olimpíadas do Rio de Janeiro lançou o dossiê que reunia uma série de documentos que provaram as violações de direitos humanos ocorridas em função de projetos urbanísticos no contexto dos megaeventos, com destaque para Copa do Mundo, ocorrida em 2014 e Olimpíadas que ocorrerá no Rio de Janeiro, em 2016. A publicação pontua as ilegalidades e arbitrariedades nos processos

${ }^{4}$ Eventos esportivos no Brasil ameaçam direito à moradia, diz relatora da ONU.Diponivel em : $<$ http://nacoesunidas.org/eventos-esportivos-no-brasil-ameacam-direito-a-moradia-diz-relatora-daonu/.>Acesso em 20/09/2105.

${ }^{5} \mathrm{Ibd}$. Acesso em 20/09/2105. 
de remoções das comunidades na cidade, entre elas a ausência de transparência do Poder Público. ${ }^{6}$

O Estatuto da Cidade e a Lei Orgânica do Município do Rio de Janeiro são instrumentos normativos que consagram disposições fundamentais para garantir o desenvolvimento das funções sociais da propriedade urbana e ocupação justa e razoável do espaço urbano. Porém esses e outros dispositivos normativos carecem de efetividade.

Assim, várias ordens expropriatórias são decretadas em violação a dispositivos consagrados nos instrumentos urbanos vigentes, objetivando atender projetos mercantilistas de modificação do espeço urbano. Desse modo, arbitrariedades perpetradas pela Administração Pública e muitas vezes ratificadas pelo Poder Judiciário expressam violação aos princípios estabelecidos na Constituição da Republica Federativa do Brasil de 1988. Visando a manutenção dos interesses das classes hegemônicas princípios constitucionais são burlados e a parcela da população menos abastada segue não tendo seus direitos garantidos.

Um dos atuais e mais representativos casos de remoções no Município do Rio de Janeiro é a que atinge os moradores da Vila Autódromo, localizada na Barra da Tijuca. A comunidade que existe há mais de 40 anos tem sua existência ameaçada pelo Município que tem removido os moradores da localidade sob a justificativa de "interesse público".

Desde a década de 90, durante a gestão do Prefeito Cesar Maia, a municipalidade tem apresentado diferentes fundamentos para remoção da referida comunidade. Em 1993, o Poder Público afirmou que a Vila Autódromo causaria dano ambiental, estético, paisagístico e turístico. Em 2009, quando foi anunciado que o Rio de Janeiro seria a sede dos jogos olímpicos, a remoção da Vila Autódromo passou a ser fundamentada na

\footnotetext{
${ }^{6}$ Copa e Olímpiadas: Dossiê reúne denuncias de violações de direitos humanos no Rio de Janeiro. Publicado em 18/04/2012 . Disponível $\mathrm{m}$ em : https://comitepopulario.wordpress.com/tag/relatoria-da-onu-pelo-direito-a-moradiaadequada/.Acesso e 20/09/2015.
} 
implantação de obras para fins do evento. Em março de 2015, sob a justificativa de interesse público, a prefeitura do Estado do Rio de Janeiro assinou decreto para a desapropriação de imóveis localizados na Vila Autódromo.

Observa-se que a municipalidade apresenta várias justificativas para o ato de remoção da Vila Autódromo. Desse modo, a presente monografia objetiva analisar as justificativas apresentadas pela Prefeitura do Município do Rio de Janeiro para remoção da comunidade sob ótica dos princípios constitucionais que regem atuação da Administração Pública, bem como o direito de permanência dos moradores da área objeto de estudo.

Trata-se de estudo de caso específico tendo por objeto o ato administrativo de remoção da Vila Autódromo cujas justificativas alteraram-se ao longo de décadas. Assim, o presente estudo irá analisar os fundamentos de tal ato (ou a inexistência dele) ato sob ótica dos princípios constitucionais e do direito de permanência visando auferir se os mesmos foram observados pela municipalidade no caso.

Para atingir o referido objetivo o trabalho foi dividido em três capítulos. O primeiro capítulo visa analisar as premissas teórico-normativas que vinculam a atuação do poder público em casos de remoções. Assim, estrutura os princípios vinculantes que permeiam a atuação da administração pública e se debruça sobre estudo do motivo do ato administrativo.

É importante ressaltar que não são analisados todos os princípios, mas aqueles que são a base para os atos administrativos, a saber, os previstos no caput do artigo 37 da $\mathrm{CRFB} / 88$, em especial, os princípios da legalidade, moralidade, publicidade e transparência.

Além desses princípios será realizada uma breve análise do princípio da supremacia do interesse público. O estudo de tal princípio mostra-se crucial na medida em que é principal justificativa para remoção dos moradores da Vila Autódromo. É importante destacar que o presente trabalho não se propõe analisar a evolução histórica dos referidos princípios 
tampouco realiza estudo aprofundado dos mesmos. Mas pontua os princípios que vinculam a atuação administrativa tendo por base o novo paradigma que emergiu com o sistema democrático e dos direitos fundamentais.

O primeiro capítulo também se dedica analisar as premissas que fundamentam o direito de permanência das comunidades erguidas a longo período de tempo. Trata-se de limitação à atuação da Administração o respeito ao direito de permanência dos moradores. Tal estudo mostra-se peremptório para objetivo buscado visto que é apresentada a base teóriconormativa que fundamenta o direito de não remoção dos moradores da Vila Autódromo diante de atos administrativos escusos.

Os moradores teriam direito de permanecer na área? Haveria algum interesse individual a ser tutelado por trás do ato do Poder Público? Faria a remoção da Vila Autódromo parte do projeto de mercantilização do espaço urbano? O Poder Público municipal fundamentou o ato de remoção da referida comunidade?

Estas perplexidades constituem a tônica da presente monografia.

Desse modo, no segundo capítulo é apresentado, sucintamente, o modelo de "cidade negócios", ou seja, políticas urbanísticas que visam à elitização do espaço e satisfação de interesses econômicos. A breve análise demonstra que a cidade, inserida no contexto de produção capitalista, tornou-se mercadoria que precisa ser atraente.

Esse modelo de cidade direciona diversas políticas públicas, inclusive remocionistas, visando tornar a cidade produto de troca que satisfaça interesses de determinadas classes e grupos. O capítulo verificará, ainda, se tal projeto de "cidade negócios" foi ou está sendo verificado no Rio de Janeiro no contexto dos megaeventos, mas especificamente na pratica remocionista da Vila Autódromo.

O terceiro capítulo, por fim, destina-se a realizar o estudo do caso, confrontando as (ausência de) justificativas para remoção da Vila Autódromo com o referencial teórico, a saber, a legislação e com conceitos 
dos princípios estudados. O capítulo inicialmente faz uma breve contextualização fática, mas sem objetivo de aprofundar todos os acontecimentos que marcaram as tentativas de remoção da comunidade.

Dando seguimento ao trabalho, o capítulo sistematiza os motivos apresentados (quando apresentados) pelo Munícipio do Rio de Janeiro para remoção da referida comunidade. Tal capítulo analisará se o ato do Município de determinar a remoção da Vila Autódromo foi fundamentado e se os motivos apresentados são reais, idôneos e visam atingir o interesse público.

Assim, o capítulo parte do pressuposto, que será explicitado no capítulo 1, que a ausência de fundamentação do ato (remocionista) e apresentação de diferentes justificativas, não idôneas ou não comprovadas, representam violação dos princípios constitucionais que regem a atuação da Administração Pública e do direito de não remoção dos moradores. Desse modo, o capítulo verifica se o ato de remoção, mais especificamente as justificativas (não) apresentadas, da Vila Autódromo observou as premissas normativas delineadas no capítulo primeiro.

O trabalho envolveu estudos teóricos utilizando fontes bibliográficas, documentais, análises de veículos midiáticos; pareceres técnicos sobre o tema e análise de peças jurídicas fornecidas pelo Núcleo de Terras e Habitação da Defensoria Pública Estado do Rio de Janeiro e extraídas de processos judiciais. O auxílio do Procurador de Justiça, Leonardo de Souza Chaves, e da Defensora, Maria Lúcia de Pontes, com constantes trocas, foi crucial para obter informações sobre o caso.

A presente monografia teve como principal obstáculo o tempo. Entretanto, espera-se, humildemente, que contribua para maiores estudos sobre o tema e para análise crítica dos atos da Administração Pública carioca que determina remoções, entre eles a não fundamentação (ou fundamentação falaciosa), que representam violação dos princípios constitucionais e ao direito a não remoção. 
São necessárias que esta e outras ilegalidades tão presentes e assoladoras das favelas cariocas sejam apuradas e, assim, tomadas as providências necessárias para saná-las. 


\section{Capítulo 1. Princípios vinculantes da atuação da Administração Pública e direitos fundamentais- Premissas teóricas normativas em caso de remoções de favelas.}

$\mathrm{O}$ administrador público deve concretizar os anseios do constituinte originário, buscando a construção de uma sociedade livre, justa e solidária, a erradicação da pobreza, da marginalização e redução das desigualdades sociais e regionais, bem como a promoção do bem de todos (art. 3 da CRFB/88). Para atingir tais objetivos, no contexto do Estado Democrático de Direito, a atuação da Administração Pública brasileira encontra-se vinculada aos princípios expressamente positivados no ordenamento e aos implícitos, considerados derivações do primeiro.

Destarte, com a adoção do sistema de direitos fundamentais $e$ sistema democrático o administrado deixa de ser súdito, passando a ser considerado cidadão, não sendo apenas destinatário das políticas públicas, mas titular do poder dentro de um modelo de Estado fundamentado na soberania popular. Assim, a atuação da Administração Pública, na atualidade, passa a ser guiada pelas diretrizes estabelecidas pela teoria democrática e dos direitos fundamentais traduzidos em preceitos constitucionais. $^{7}$

A democracia é a forma de governo que estabelece que os cidadãos sejam protagonistas das decisões política-jurídicas do Estado. Desse modo, no contexto democrático, passa a ser discutida a legitimação da ação administrativa, em função da constitucionalização do direito administrativo e na democratização do exercício de tal atividade. ${ }^{8}$

Com advento do sistema democrático, o agir administrativo passa encontrar limite em regras, valores e postulados constitucionais, mediante juízos de ponderação racional, e, os direitos fundamentais passam a

\footnotetext{
7 BINENBOJM, Gustavo. Uma teoria do direito administrativo, democracia e constitucionalização, $3^{\mathrm{a}}$ ed. revista e atualizada, Rio de Janeiro: Renovar, 2014, p.24.

${ }^{8} \mathrm{O}$ presente estudo não irá tratar da constitucionalização do direito administrativo tampouco da democratização da atividade. Sobre o tema recomenda-se a leitura de BAPTISTA, Patrícia Ferreira. Transformações do Direito Administrativo. Rio de Janeiro: Renovar,2003,p.120 e ss.
} 
proteger o cidadão contra o Estado e de outro lado, geram um conjunto de prestações positivas ou normativas, que devem ser realizadas pelo Poder Público. ${ }^{9}$

Desse modo, no contexto do sistema democrático e dos direitos fundamentais, em caso de remoções a Administração Pública encontra-se vinculada a várias premissas teórico-normativas. Entre as premissas destacam-se as previstas na Constituição do Estado do Rio de Janeiro (art. $234^{\circ}$, I) e na Lei Orgânica do Município do Rio de Janeiro (art. 429).

Tais dispositivos normativos citados consagram, entre outros direitos, o direito a não remoção, entretanto, a admite excepcionalmente, e para realizá-la, a Administração Pública deve obediência às regras, valores e postulados constitucionais. Desse modo, é necessária, entre outros deveres, a fundamentação expressa do ato, participação da comunidade interessada para análise do ato e definição de soluções, assentamento em localidade próxima, e ainda, observância ponderada de todas as demais normas.

Destarte, o presente capítulo objetiva analisar as premissas teóricas normativas basilares que vinculam a atuação do poder público em casos de remoções. Inicialmente o capítulo debruçará sobre análise de determinados princípios constitucionais, dando seguimento, será realizada uma breve digressão sobre interesse público, tendo em vista que se trata do principal fundamento para remoção das favelas cariocas. Por fim, o capítulo tratará do direito a não remoção que deve guiar a atuação da Administração Pública em tais casos.

\footnotetext{
${ }^{9}$ MENDES, Gilmar Ferreira Mendes, Direitos Fundamentais e Controle de Constitucionalidade. São Paulo: Celso Bastos Editor, 1988,pg 32/33. Nesse sentido, v.g. o direito de ir e vir pressupõe que o Poder Público realize uma série de atividades destinas a preservar tal direito, como serviços de segurança pública.
} 


\subsection{Princípios vinculantes da Administração Pública.}

\subsubsection{Legalidade, impessoalidade, moralidade publicidade.}

Com base na Teoria da Separação dos Poderes, ao Legislativo caberia elaborar o direito, ou seja, preceitos jurídicos que limitariam e guiariam a atuação dos órgãos administrativos, e, Administração Pública caberia à execução do direito posto. Destarte, emerge a legalidade, uma vez que ninguém poderia ter sua liberdade tolhida a não ser em virtude de lei ${ }^{10}$, desse modo, a Administração Pública estaria vinculada a lei, cabendo apenas a aplicação do direito de ofício. ${ }^{11}$

O referido princípio teria aplicação diversa à Administração Pública, se ao particular, no exercício da autonomia privada, cabe fazer tudo exceto aquilo que não lhes for vedado, ao Estado cabe apenas agir de acordo com a lei, o que se chama de legalidade estrita.

A concepção tradicional da legalidade administrativa evidencia a "vinculação positiva a lei."12 Entretanto concepção de que a atuação administrativa restringe-se a aplicação mecânica da lei é anacrônica no contexto da adoção do sistema de direitos fundamentais e democrático. Ademais, a segunda metade do século $\mathrm{XX}$ foi caracterizada pelo desprestígio da lei como expressão da vontade geral. ${ }^{13}$ Assim, a o conteúdo da lei, muitas vezes, carecia de legitimidade.

Concepção contemporânea traduz que o princípio da legalidade no âmbito da Administração Pública não se circunscreve apenas a aplicação da

\footnotetext{
10 OLIVEIRA, Marcelo Andrade Cattoni de. Direito constitucional. Belo Horizonte: Mandamentos,2002. pg. 57-58.

${ }^{11}$ FAGUNDES, Miguel Seabra. O controle dos atos administrativos pelo Poder Judiciário. 8. ed. Rio de Janeiro: Forense, 2010. pg. 3.

12 JUSTEN FILHO, Marçal apud Gustavo Binenbojm. Uma teoria do direito administrativo: direitos fundamentais, democracia e constitucionalização.pg 23

13 FERREIRA FILHO, Manoel Gonçalves apud Gustavo Binenbojm. Uma teoria do direito administrativo: direitos fundamentais, democracia e constitucionalização. 2. ed. Rio de Janeiro: Renovar, 2008 .pg 23.
} 
lei, mas aplicação de todo ordenamento jurídico. Desse modo, o arcabouço jurídico normativo que irá guiar a atuação administrativa tem sua base na Constituição, nas suas regras e princípios, sobretudo o sistema de direitos fundamentais e democrático. Assim, a principiologia constitucional passa ocupar o cerne do direito administrativo democrático que deve comprometer-se com a realização dos direitos dos fundamentais.

Emerge, assim, o conceito de juridicidade administrativa desenvolvido a partir dos preceitos constitucionais. Tal conceito engloba o que se chama de legalidade administrativa. Isso significa que o agir da Administração está pautado não apenas na lei, mas em todo arcabouço jurídico normativo: na Constituição, na lei-quando esta for constitucional-; e preceitos constitucionais-quando não houver lei, e em todo direito.

Nesse sentido, a partir da ponderação da legalidade e demais princípios constitucionais envolvidos ${ }^{14}$, algumas situações ensejam atuação contra o conteúdo positivo da lei. Existem casos em que a autoridade administrativa não se reporta a uma lei específica, mas ainda assim o administrador púbico deve ser autorizado a agir, daí a importância dos princípios, que não esgotam a atuação administrativa na lei. ${ }^{15}$

Existe, portanto, acepção dialética do princípio da legalidade, eis que "a lei deixa de ser o fundamento único e último da atuação da Administração Pública para se tornar apenas um dos princípios do sistema de juridicidade instituído pela Constituição". ${ }^{16}$ Destarte, a atuação da Administração Pública é vinculada não apenas à lei em sentido estrito, como também a todo sistema jurídico vigente, que abrange os princípios que o embasam, entre eles, os princípios da impessoalidade, moralidade, publicidade e eficiência (art. 37 caput CRFB/88).

\footnotetext{
14 BINENBOJM, Gustavo. Uma teoria do direito administrativo: direitos fundamentais, democracia e constitucionalização. pg. 38

${ }^{15}$ Em que pese não vedada por lei ( apenas súmula vinculante $\mathrm{n}^{\circ} 13$ ), a pratica do nepotismo é rechaçada pois é incompatível com os princípios da impessoalidade e moralidade pública.

16 BINENBOJM, Gustavo. Uma teoria do direito administrativo: direitos fundamentais, democracia e constitucionalização. pg. 70.
} 
O princípio da impessoalidade se traduz na ideia que a Administração Pública deve agir de modo imparcial, tratando todos os administrados igualmente ${ }^{17}$, sem favoritismos ou discriminações. Tal princípio dialoga com a finalidade do ato administrativo, "porque é evidente que o privilégio representa em si a finalidade privada que a Administração Pública deveria recusar-se a alcançar". ${ }^{18}$

O tratamento impessoal que se determina para Administração toca ao princípio da moralidade pública, pois se exige do agente público conduta pautada por preceitos éticos que tenha como fim último a consecução do bem comum. Assim, exige-se da Administração dever de honestidade em relação aos recursos que o Estado tutela, múnus de zelo pela res pública e boa-fé e lealdade para com os administrados.

Segundo as diretrizes impostas pela boa-fé e lealdade a Administração deverá, em relação aos administrados, proceder com sinceridade, sendo-lhe vedado comportamento eivado de "astúcia com intuito de prejudicar o exercício de direitos por parte dos cidadãos”. Ainda, por força dos referidos princípios, Celso Antônio Bandeira de Mello, atenta para o fato de que "as orientações firmadas pela Administração em dada matéria não podem, sem prévia e pública notícia, ser modificada em casos concretos a fim de sancionar ou agravar a situação dos administrados(...)" ${ }^{19}$

Além de previsto no caput do art. 37 da Constituição, o princípio da moralidade administrativa, encontra-se esculpido no rol das garantias individuais, art. $5^{\circ}$, LXXIII, que prevê a possibilidade de ajuizamento da ação popular para anulação de ato lesivo à moralidade administrativa.

A moralidade pública, legalidade ou impessoalidade não pode ser concebida destacada da publicidade. No contexto do Estado democrático de

\footnotetext{
17 Aplica-se a igualdade material, buscando atingir a efetiva isonomia e realização da justiça distributiva.

18 WERNECK, Augusto. República, Democracia e os princípios Constitucionais da Administração Pública: $O$ caso do nepotismo e a permanência do patrimonialismo. pg. 6 Disponível em: $\quad<\quad$ http://www.cis.pucrio.br/cis/cedes/PDF/09julho/republica $\% 20 \mathrm{e} \% 20$ impessoalidade_augusto $\% 20$ werneck.pdf $>$ Acesso em $17 / 09 / 2015$

19 MELlO, Celso Antônio bandeira de. Curso de Direito Administrativo,28 ${ }^{\mathrm{a}}$ ed. São Páulo:Medeiros .pg. 120.
} 
direito é necessário que os atos estatais sejam conhecidos de todos. Entretanto, a publicidade não se reduz a mera publicação e divulgação dos atos administrativos, mas traduz o ônus do Poder Público ser transparente e eficiente na interlocução.

O princípio da publicidade conduz a elaboração de regras específicas que exigem transparência em relação às políticas urbanas. Nesse sentido, destaca-se a Lei Orgânica do Município do Rio de Janeiro que consagra o direito à informação sobre os atos do Poder Público em relação à política urbana (art. 458). Estabelecendo o dever da Administração de garantir os meios "para que a informação chegue aos cidadãos, dando-lhes condições de discutir os problemas urbanos e participar de suas soluções" (parágrafo único do referido dispositivo).

A participação da população no planejamento e na execução das políticas urbanas é prevista em vários dispositivos normativos. Nessa acepção, cita-se o art. 2, II do Estatuto da Cidade (Lei Federal n ${ }^{\circ} 10.257$ de 2001) e o art. 2, IV e art. 3, XXV do Plano Diretor Municipal da Cidade do Rio de Janeiro (Lei Complementar $\left.n^{\circ} 111 / 2011\right)$.

A participação popular na gestão das políticas urbanas só é possível com a publicidade dos atos. É preciso que o Poder Público garanta que a informação chegue aos cidadãos. Nesse esteio, Celso Antônio Bandeira de Mello pontua que o Poder Público não pode "ocultar aos administrados assuntos de seu interesse" 20 , sendo necessária a observância aos deveres de honestidade, imparcialidade, legalidade, e lealdade às instituições.

Daí o conteúdo desses princípios expressamente positivados na Constituição Federal conduz aos princípios implícitos, como o princípio da motivação dos atos administrativos, que é auxiliar ao princípio da publicidade. A Administração Pública tem o dever de fundamentar seus atos de forma suficiente, ou seja, há o dever de justificá-los, apresentando os fundamentos de fato e de direito, bem como as situações preexistentes que deram origem a tal ato.

${ }^{20}$ MELLO, Celso Antônio bandeira de .Curso de Direito Administrativo.pg. 114. 
O caput do art. 2 da Lei federal $n^{\circ} 9.784 / 1999$, que regula o processo administrativo no âmbito da Administração Pública Federal, prevê expressamente a motivação como princípio norteador da Administração. $\mathrm{O}$ art. 50 do referido dispositivo normativo explicita as situações de fato e de direito que obrigam o ente público a motivar o ato. Entre as hipóteses destacam-se as que "neguem, limitem ou afetem direitos ou interesses" (inciso III).

Não obstante inexistir expressamente na Constituição Federal, o dever de motivação está implícito e decorre dos preceitos constitucionais abrigados no contexto do sistema democrático e de direitos fundamentais. Grande parte da doutrina afirma que existe dever de motivação, ou seja, a regra é a de que os atos administrativos, discricionários ou vinculados, sejam motivados expressamente. Entre os autores que sustentam tal entendimento destacam-se Celso Antônio Bandeira de Mello e Maria Sylvia Zanella Di Pietro. ${ }^{21}$

Tais autores sustentam que a motivação do ato administrativo é fundamental para o exercício do controle e para evitar que o Estado utilize seu poder de forma arbitrária. Assim, o dever de motivação objetiva dar concretude ao princípio da juridicidade.

Desse modo, em caso de remoções o Poder Público além de agir com impessoalidade e boa-fé, tem o dever de motivar expressamente tal ato. Se Administração Pública não motiva o ato ou se a motivação apresentada é falsa, maliciosa ou exposta de maneira equivocada há violação dos princípios anteriormente elucidados.

\footnotetext{
21 TEIXEIRA, Bruno Cesar Gonçalves. Obrigatoriedade de motivação dos atos administrativos. In: Âmbito Jurídico, Rio Grande, XII, n. 65, jun 2009. Disponível em: $<$ http://www.ambitojuridico.com.br/site/index.php?n_link=revista_artigos_leitura\&artigo_id=613 1>. Acesso em 30 de outubro de 2015.
} 


\subsubsection{Pressuposto do Ato Administrativo: Motivo}

Celso Antônio Bandeira de Mello em seu manual de Direito Administrativo evidencia que o objeto e a pertinência do ato são pressupostos de existência e o sujeito, motivo, finalidade, requisitos procedimentais, causa e formalização constituem pressupostos de validade do ato administrativo. A seguir será realizado breve estudo sobre o motivo do ato administrativo.

Motivo é a situação fática ou de direito, ocorrida previamente, que autoriza a Administração Pública agir. Pode estar previsto em lei ou não. Quando previsto em lei o administrador público apenas está autorizado a agir se houver ocorrido a situação descrita na lei. Quando não previsto em lei, segundo o autor, há possiblidade de escolha do motivo pela administração, entretanto, só poderá ser considerado os motivos admitidos pela lei e que corresponda a pressupostos fáticos ou jurídicos idôneos.

A validade do ato administrativo depende da existência de motivo prévio e idôneo, assim, se o motivo do ato for inexistente ou não for idôneo o ato será eivado de nulidade. Nos termos do art. $2^{\circ}$ da da Lei de Ação Popular (Lei. 4.717/1965) $a$ "inexistência dos motivos se verifica quando a matéria de fato ou de direito, em que se fundamenta o ato, é materialmente inexistente ou juridicamente inadequada ao resultado obtido". Na parte final do referido dispositivo normativo o legislador ordinário utiliza o critério da razoabilidade - utilizando a expressão "juridicamente inadequada" - para evidenciar vício relativo ao motivo.

Assim, para fins de análise da legalidade do próprio ato é necessário verificar se o motivo em função do qual foi praticado o ato realmente ocorreu, verificar se é idôneo, razoável e se, o motivo estiver previsto em lei, a correspondência necessária entre o motivo que embasou o ato com o motivo legal. ${ }^{22}$

\footnotetext{
${ }^{22}$ MELLO, Celso Antônio Bandeira de. Curso de Direito Administrativo. pg. 398
} 
Caso o motivo que embasou o ato não tiver previsão legal, há espaço para o exercício da competência discricionária, segundo critérios de conveniência e oportunidade. ${ }^{23}$ Maria Zanella de Pietro afirma que a discricionariedade quanto aos motivos ocorre quando não há definição legal do motivo ou quando a lei o definiu usando conceitos vagos e imprecisos. Desse modo, caberá ao agente público agir nos limites do proporcional e razoável para atingir a finalidade adequada, visando o respeito aos motivos implícitos na $1 \mathrm{ei}^{24}$ ou daqueles que foram definidos por meio de expressões vagas ou palavras plurissignificativas.

Assim, a discricionariedade envolve a adoção da medida mais adequada visando à satisfação da finalidade prevista em lei ${ }^{25}$. Com emergência da ideia de juridicidade administrativa, os atos administrativos, inclusive discricionários, encontram-se vinculados diretamente às disposições constitucionais. Desse modo, o motivo e a fundamentação dos atos, ainda que discricionários, e as politicas públicas também se encontram vinculados ao conteúdo dos princípios que regem a atuação da Administração Pública.

Daí que não se estabelece mais dicotomia absoluta entre atos vinculados e discricionários, mas o que difere um do outro são os graus de vinculação dos atos à juridicidade. Uns encontram-se vinculados a regras expressas, outros a conceitos jurídicos indeterminados e outros aos conteúdos dos princípios previsto no ordenamento, desse modo, inclusive o mérito administrativo sofre incidência dos princípios constitucionais.

Destarte, o motivo do ato também se encontra vinculado às regras e princípios constitucionais. Caso, por exemplo, a intenção do agente público que motivou o ato for eivada por sentimentos escusos, como favoritismo,

\footnotetext{
${ }^{23}$ Moreira Neto, citado por Gasparini, afirma que a conveniência é observada quando o "conteúdo jurídico de um ato convém à produção de um resultado que, em tese, está adequado aoatendimento de sua finalidade", já oportunidade é verificada quando "considerados os pressupostos de fato e de direito, o momento da ação é o adequado à produção desse resultado que, em tese, atende sua finalidade”. Moreira Neto apud GASPARINI, Diógenes. Direito administrativo. 8. ed. São Paulo: Saraiva, 2003. pg. 91.

24 DI PIETRO, Maria Sylvia Zanella. Direito administrativo. 23. ed. São Paulo: Atlas, 2010.P. 215.

${ }^{25}$ MELLO, Celso Antônio Bandeira de .Curso de Direito Administrativo. p.981
} 
visando o atendimento de interesses individuais, o ato administrativo será inválido. ${ }^{26}$

O Superior Tribunal de Justiça destaca que o exame da validade do ato passa pela análise do motivo. Em recentes julgados destacou que os motivos explicitados pela Administração para pratica de determinado ato vinculam o administrador, portanto, havendo vício de legalidade não apenas quando inexistente os motivos, mas também quando "verificada a falta de congruência entre as razões explicitadas no ato e o resultado nele contido". ${ }^{27}$ No mesmo sentido cita-se a manifestação pretoriana proferida pelo mesmo órgão o qual afirmou que os "motivos embasadores dos atos administrativos vinculam a Administração, conferindo-lhes legitimidade e validade", 28

O motivo do ato como pressuposto do ato administrativo traz o dever de motivação do mesmo. Conforme já mencionado, a motivação é a formalidade do ato, ou seja, a forma pela qual a Administração Pública indica os fundamentos de fato e de direito que justificam a prática do ato.

Se todo poder emana do povo, os titulares do poder possuem o direito de saber o motivo pelo qual o ato foi praticado, isto é, os fundamentos fáticos e jurídicos que justificam o ato. Ainda que esses atos sejam praticados no exercício da competência discricionária da administração há necessidade que ele seja motivado sob pena de estar eivado de vício, já que a Administração poderia buscar motivo, "inventar", posteriormente para justificar o ato. ${ }^{29}$

Mesmo que a lei não exija expressamente motivação, o ato deve ter motivo prévio e idôneo, e, é possível que a Administração demostre que motivo previamente existia, que era idôneo e que foi determinante para

\footnotetext{
${ }^{26}$ MELLO, Celso Antônio Bandeira de .Curso de Direito Administrativo. p. 399. Nesse sentido é mister salientar a teoria dos motivos determinantes que pontua que os motivos que determinam a vontade do agente público integram a validade do ato administrativo.

${ }^{27}$ MS 15.290/DF, Rel. Min. Castro Meira, Primeira Seção, julgado em 26.10.2011, DJe 14.11.2011.

${ }^{28}$ AgRg no REsp 1280729 / RJ, julgado em 10/04/2012, DJe 19/04/2012.

${ }^{29}$ MELLO, Celso Antônio Bandeira de .Curso de Direito Administrativo. p.403.
} 
prática do ato ${ }^{30}$, uma vez que o titular do poder tem o direito de conhecer o motivo que fundamentou a pratica do ato administrativo.

Além do motivo, a finalidade também é pressuposto de validade do ato. Definida como o "bem jurídico objetivado pelo ato"31 ,ou seja, é o resultado (mediato) que o ato administrativo objetiva alcançar. $\mathrm{O}$ fim último almejado pela Administração Pública deve ser interesse público. Nesse sentido é importante as considerações que serão feitas sobre tal interesse. ${ }^{32}$

Desse modo, uma desapropriação feita não porque o administrador precisa daquele bem para atender o objetivo comum, mas para atender interesses pessoais ou para beneficiar apoiadores está eivada de vício visto que não objetiva atender o interesse público. A Lei de Ação Popular dispõe, em seu artigo $2^{\circ}$, que são nulos os atos lesivos ao patrimônio no caso de desvio de finalidade, e o caracteriza quando o "agente pratica o ato visando a fim diverso daquele previsto, explícita ou implicitamente, na regra de competência."

Diante de todo exposto, conclui-se que se o Poder Público determina a remoção de favela é preciso que este fundamente expressamente o motivo que embasou tal ato. Se não houver motivos para a prática do ato ou se este não for idôneo ou juridicamente inadequado, o ato será eivado de nulidade e atuação da Administração Pública violará a juridicidade, uma vez que o ordenamento jurídico exige que o ato administrativo seja provido de motivo prévio e idôneo.

É importante salientar que, conforme se explicará adiante, o agente público deve buscar a solução mais adequada visando à satisfação da

\footnotetext{
${ }^{30}$ MELLO,Celso Antônio Bandeira de .Curso de Direito Administrativo p.403.

${ }^{31}$ Ibid. p.403.

32 Enquanto Helly Lopes Mereilles afirma que a finalidade de todo ato administrativo deve ser o interesse público, Maria Zanella de Pietro apresentada a finalidade em outro sentido. Afirmando que a finalidade é o resultado determinado que cada ato deve produzir em virtude de lei. Quando um ato é praticado para atingir uma finalidade que não lhe é atribuída ocorre desvio de finalidade. Por exemplo, se um funcionário público pratica uma falta grave, a Administração deve praticar um ato com finalidade punitiva, não deve, por exemplo, exonera-lo visto que exoneração não tem finalidade punitiva.
} 
finalidade prevista em lei ${ }^{33}$. Desse modo, o motivo para remoção da comunidade só será idôneo se for imprescindível, razoável, proporcional e adequado.

A motivação e a finalidade do ato não são apenas verificadas com a exposição de motivos de um ato administrativo, por hipótese, mas para perquiri-la é necessário analisar o conteúdo outros princípios bem como a razoabilidade e proporcionalidade. Além de proporcional e razoável o ato administrativo deve visar atingir o interesse público.

\subsubsection{Supremacia do Interesse Público}

Um dos princípios clássicos implicitamente considerados que informam o direito administrativo é a supremacia do interesse público sobre o privado. Consoante tal princípio a Administração Pública deve conduzir seus atos visando atender os interesses da coletividade, que é a titular dos interesses juridicamente protegidos.

Segundo a concepção majoritária o interesse público estaria associado à noção de bem comum. ${ }^{34}$ Nesse sentido, a supremacia do interesse público traduz a ideia de que havendo conflito entre os direitos individuais e da sociedade, este último deve prevalecer. Entretanto, alguns autores criticam tal princípio, uns propondo sua abolição e outros sua reformulação. ${ }^{35}$

\footnotetext{
33 MELLO, Celso Antônio bandeira de. Curso de Direito Administrativo,28 ${ }^{\mathrm{a}}$ ed. São Paulo: Medeiros pg.981

34 BINENBOJM, Gustavo. Uma teoria do direito administrativo: direitos fundamentais, democracia e constitucionalização.pg. 30. Nesse sentido Binenbojim cita Celso Antônio Bandeira de Mello e Helly Lopes Meirelles.É importante evidenciar que que há antiga divisão do interesse público em primário e secundário delineado inicialmente no Brasil por Celso Antônio Bandeira de Mello. O primeiro seria aquele relacionado aos próprios fins do Estado enquanto o segundo seria o interesse da pessoa jurídica de direito público.

${ }^{35}$ Nesse contexto destacam-se Humberto Ávila, Alexandre Santos de Aragão, Daniel Sarmento, Gustavo Binenboijm e Paulo Ricardo Schier. Estes posicionamentos encontram-se compilados na obra organizada por Sarmento: SARMENTO, Daniel(org) Interessses públicos versus interesses privados: descontruindo o princípio da supremacia do interesse público, Rio de Janeiro: Luen Juris, 2005.
} 
Gustavo Binenboijm é um dos autores que propõe sua abolição. O referido autor afirma que essa concepção de separação inconfundível entre interesse público e interesses individuais, e, a supremacia absoluta dos interesses metaindividuais ${ }^{36}$ é incompatível com a constitucionalização do direito administrativo e com "consagração dos direitos fundamentais e da democracia como fundamentos da legitimidade e de elementos estruturantes do Estado democrático de direito."37

O interesse público não é a somatória dos direitos individuais, mas é aquele interesse que emerge da vivência em comunidade, sendo interesse de todo conjunto social, uma imbricação entre interesses individuais e interesses da coletividade. Segundo Binenboijm, tal interesse não se trata de pressuposto abstrato que traz em si a ideia prévia de prevalência de determinados interesses.

Com efeito, para se verificar o interesse que deve prevalecer, o administrador deve utilizar os postulados da razoabilidade e da proporcionalidade- adequação, necessidade e proporcionalidade em sentido estrito $^{38}$-, exercendo assim um juízo de ponderação entre os direitos individuais e coletivos específicos em tela que permita a aplicação máxima dos interesses envolvidos. ${ }^{39}$

Desse modo, visando a concretização dos direitos fundamentais, e não sua limitação em prol de interesse da coletividade, impõe-se à

\footnotetext{
${ }^{36}$ A doutrina clássica associa o interesse público aos interesses coletivos e metaindividuais.

37 BINENBOJM, Gustavo. Uma teoria do direito administrativo: direitos fundamentais, democracia e constitucionalização. pg 30. Cabe ressaltar que Humberto Ávila, pioneiramente, demonstrou "o vazio conceitual" da supremacia do direito público sobre o privada na obra "O princípio da supremacia do interesse público sobre o particular". Além da teoria clássica e contemporânea, que propõe a inexistência da supremacia de um interesse, há a teoria intermédia apresentada por Luís Roberto Barroso que sustenta a supremacia do interesse público primário( prefácio ao livro Interesses Públicos versus Interesses Privados: desconstruindo o princípio da supremacia do interesse público).

${ }^{38}$ Trata da tríplice estrutura do postulado da proporcionalidade, ver: Ávila, Humberto Bergmann. Teoria dos Princípios: da definição à aplicação dos princípios jurídicos. São Paulo:Malheiros, 2004. Nessa seara a restrição de um interesse é apenas justificada quando não houver outra solução menos onerosa, se garantir o outro interesse em conflito e se o benéfico atingido compensar a restrição ao interesse contraposto. Nesse sentido recomenda-se a leitura : SARMENTO, Daniel.A Ponderação de Interesses na Constituição Federal, $1^{\circ}$ ed, $3^{\circ}$ tir. Rio de Janeiro Lumen Juris,2003.

39 Apenas é possível falar ponderação entre interesses públicos e particulares quando estes são legítimos. Favoritismos pessoais em jogo não podem ser considerados, visto que estes envolve per ser violação aos princípios da impessoalidade e moralidade administrativa .
} 
Administração Pública o dever de realizar a ponderação racional, não podendo, falar antecipadamente em prevalência do interesse coletivo sobre o individual ou do público sobre o privado. Segundo Binenboijm "muitas vezes, a promoção do interesse público, entendido como conjunto de metas gerais da coletividade juridicamente consagrada-consiste justamente na preservação de um interesse individual, na maior medida possível". 40

Segundo o autor, em determinadas situações o constituinte originário vislumbrou a hipótese de conflito entre interesses individuais e coletivos e, antecipadamente, exerceu a ponderação dos mesmos. A título exemplificativo cita-se o conflito entre o direito de propriedade e o interesse coletivo da realização de determinas obras públicas, o qual seja necessária e expropriação de determinados bens particulares.

Nesse caso, o Constituinte prevê a possibilidade de desapropriação mediante o pagamento de justa e prévia compensação. ${ }^{41} \mathrm{O}$ pagamento de ressarcimento justo enseja uma situação intermédia entre a supressão completa do direito de propriedade e a garantia do mesmo. $\mathrm{O}$ interesse público, no caso, consiste em intervenção da administração pública para preservação e promoção dos direitos envolvidos.

Entretanto é importante salientar que a desapropriação deve ser o instrumento utilizado apenas se não houver outra possibilidade de evitar restrição à propriedade. Daí a necessidade, integrante do postulado da proporcionalidade, impõe a Administração Pública adoção da solução adequada menos gravosa aos direitos individuais, como a propriedade.

No juízo do custo-benefício é necessário verificar se a realização ou promoção do interesse contraposto à propriedade compensaria a expropriação. Além disso, é necessário que tal ato administrativo ocorra em consonância com os demais princípios e regras que limitam atuação administrativo dentro do sistema democrático e dos direitos fundamentais.

\footnotetext{
${ }^{40}$ BINENBOJM, Gustavo. Uma teoria do direito administrativo: direitos fundamentais, democracia e constitucionalização. pg 324

41 JUSTEN FILHO, Marçal apud Gustavo Binenbojm. Uma teoria do direito administrativo: direitos fundamentais, democracia e constitucionalização. pg 125.
} 
Claudio Penedo Madureira critica os autores que defendem a abolição do princípio em tela ${ }^{42}$. Segundo o autor a doutrina clássica, reportando-se as lições de Bandeira de Mello, identifica o interesse público com a juridicidade, ou seja, com todos os comandos previstos no ordenamento jurídico. Desse modo, não seria equivocado sustentar a supremacia do interesse público tendo em vista que o princípio só será observado se for aplicado o conteúdo dos demais preceitos, em especial a legalidade.

Claudio Penedo afirma ainda que a espécie de pré- ponderação a ser realizada pelo Administrador vai ao encontro com a noção de interesse público expressa pela doutrina clássica, mas especificamente Celso Antônio Bandeira de Mello. Afirma, ainda, que não existe uma separação absoluta entre interesse individual e público, e que o interesse público só será idôneo se satisfazer todas as premissas do ordenamento jurídico.

No mesmo sentido cita-se Maria Zanella de Pietro. A autora afirma que a supremacia do interesse público é base do direito administrativo, uma vez que o Estado desenvolveu-se baseado na satisfação dos interesses públicos e na proteção dos direitos do indivíduo. Zanella de Pietro salienta que com o advento do Estado Social o princípio assumiu feição humanista, passando a preocupar-se com a dignidade da pessoa humana cujo objetivo é favorecer o bem estar social.

Assim, afirma que para atingir esse fim em determinadas situações o interesse público prevalece em relação ao individual. Nesse sentido, a autora afirma que o exercício ponderação razoável não implica em negação do princípio da supremacia do interesse público. ${ }^{43}$

Destarte, considerando a doutrina clássica e os argumentos defendidos pela contemporânea, defende-se a ideia que é possível sustentar

42 MADUREIRA, Claudio Penedo. Supremacia do interesse público sobre privado: uma necessária desconstrução crítica. Forúm Administrativo-FA,Belo Horizonte,ano 14,n161,p924,jul.2014.

${ }^{43}$ DI PIETRO. Maria Sylvia Zanella. O principio da supremacia do interesse público. Disponível em:<http://www.bidforum.com.br/bid/PDI00006.aspx?pdiCntd=62095.>Acesso em 21 out. 2015 A mesma ideia é defendida pela autora no livro Discricionariedade administrativa na Constituição de 1988(2001,capítulo 6). 
a prevalência do interesse público, entretanto, este deverá ser obtido a partir da ponderação razoável dos interesses envolvidos, da aplicação das premissas previstas no ordenamento jurídico. Desse modo, o "interesse público" não seria antagônico ao "interesse privado", podendo inclusive significar a tutela do interesse particular no caso concreto.

O Estado democrático de direito é o Estado da Ponderação. ${ }^{44}$ Ponderando bens, interesses e princípios previstos na Constituição, leis infraconstitucionais e infra legais. A ideia do sistema de direitos fundamentais é a proteção dos valores morais assentados na dignidade humana. O próprio sistema democrático assenta-se sobre o valor moral de igualdade (material) entre todos. Desse modo, o reconhecimento da dignidade humana e de valores que dela emanam "resulta na primazia dos direitos do homem sobre os projetos de bem estar coletivo". ${ }^{45}$

As premissas sobre interesse público expostas auxiliam a perspectiva crítica em relação à fundamentação dos atos administrativos que tem como cerne o interesse público. Administração Pública do Munícipio do Rio de Janeiro geralmente invoca a "supremacia do interesse público" objetivando remoção de favelas erguidas a longos períodos de tempo. Entretanto, conforme analisado, o interesse público não é uma categoria abstrata que serve a interesses escusos e atos autoritários.

No contexto do sistema de direitos fundamentais e democrático ainda que se sustente a prevalência do interesse público, este bem comum não se confunde com interesse de governo, do Estado ou interesse coletivo. Além disso, o interesse público não existe a priore, devendo ser obtido a partir da ponderação racional dos direitos e interesses em conflito. E esse interesse público, obtido na análise do caso concreto, que deve prevalecer.

É muito comum em caso de remoções que a fundamentação do ato esteja associada à necessidade de realização de obras públicas. Mas será

\footnotetext{
${ }^{44}$ JUSTEN FILHO. Marçal apud BINENBOJM, Gustavo. Uma teoria do direito administrativo: direitos fundamentais, democracia e constitucionalização. pg 33

${ }^{45}$ VILHENA, Oscar apud BINENBOJM, Gustavo. Uma teoria do direito administrativo: direitos fundamentais, democracia e constitucionalização. pg.87.
} 
que toda obra revela interesse público? E que interesse público é esse que se é obtido dissociado dos interesses das populações afetadas e das garantias previstas no ordenamento? E, ainda, que interesse público é esse que decorre de decisão unilateral do Estado? Seria, portanto, interesse público ou interesse dos grupos políticos do momento?

Não obstante as indagações feitas, considerando os anseios do constituinte originário de promover uma sociedade justa e solidária, a permanência e urbanização da favela em detrimento de determinadas obras públicas representam a satisfação do interesse público. Há interesse público na priorização da permanência dos moradores em comunidades carentes.

Extensos instrumentos normativos federais, estaduais e municipais consagram tal interesse. A seção seguinte analisará o assunto, mas a título explicativo destaca-se o Estatuto da Cidade (Lei 10.257/2001) que garante tal direito através dos instrumentos que visam a legalização da moradia em assentamento ditos irregulares. Entre esses se cita a regularização fundiária e a concessão de uso e concessão de uso especial para fins de moradia.

Outro exemplo é a Lei Federal n. 11.124, de 16/06/2005, que dispõe sobre o Sistema Nacional de Habitação de Interesse Social, em seu art. 4, II "c", que determina a "utilização prioritária de terrenos de propriedade do Poder Público para a implantação de projetos habitacionais de interesse social".

No âmbito da Legislação do Rio de Janeiro cita-se a Constituição do Estado do Rio de Janeiro que dispõe sobre o direito à "urbanização, regularização fundiária e titulação das áreas faveladas e de baixa renda, sem remoção dos moradores" (art. 234 $4^{\circ}$, I) e a Leia Orgânica do Município que estabelece a urbanização dos assentamentos de baixa renda assegura as funções sociais da cidade e os anseios do constituinte (art. 429).

No mesmo, sentido cita-se o Plano diretor da Cidade do Rio de Janeiro, Lei Complementar n. ${ }^{\circ} 111$ de $1^{\circ}$ de fevereiro de 2011, que no âmbito do art. 3, inciso $\mathrm{V}$ estabelece a urbanização das favelas como crucial para o pleno desenvolvimento das funções sociais da cidade. 
Além do direito de permanência representar interesse público, a execução do projeto menos oneroso e eficiente deve ser realizada pela Administração, tendo em vista que o Poder Público deve buscar os meios adequados, necessários e proporcionais para realização dos seus fins. Assim, o meio que gere menos restrição aos direitos fundamentais e cujas vantagens superem as desvantagens é o meio adequado para realização do fim público.

Muitas vezes é possível que o traçado de uma obra, por hipótese, seja alterado e ainda assim satisfaça as necessidades públicas, sendo esse menos oneroso aos cofres públicos e direitos fundamentais. Outras vezes o ato remoção sequer visa atender interesse público e sim interesses de Estado ou dos grandes atores do cenário econômico, conforme será tratado no capítulo 2, e assim, viola a juridicidade administrativa uma vez que é desprovido de finalidade e motivo.

Desse modo, é importante o viés crítico em relação aos atos do Poder Público que determinam a remoção das comunidades fundamentadas no interesse público, uma vez que tal categoria não é abstrata e só é extraída na análise do caso concreto.

É importante mencionar que o ato do Poder Público que determina a remoção deve ser informado pela legalidade, moralidade, isonomia, publicidade e eficiência e, ainda, pelas limitações prevista na Constituição e leis infraconstitucionais. Devendo, assim, constituir medida de caráter excepcional fundamentada/motivada de forma criteriosa .

E, se fundamentada no interesse público só será válida se o motivo específico for prévio, idôneo, adequado, necessário e proporcional. Ou seja, se $\mathrm{o}$ ato for o único capaz de gerar menos restrição aos direitos fundamentais e cujas vantagens superem as desvantagens, e ainda, for o meio mais adequado para realização do fim público.

Cabe ressaltar que a Constituição da República Federativa do Brasil estabelece, entre outros, a dignidade humana com fundamento do Estado Democrático (art.1, inciso III), desse modo, estabelecendo a proteção da 
dignidade do indivíduo quando na iminência de ser violada em frente aos interesses coletivos. ${ }^{46}$

Destarte, o que deve prevalecer é o resultado da ponderação razoável e racional dos interesses envolvidos, tanto dos interesses particulares/individuais quanto gerais/da coletividade. Assim, a tutela do direito a não remoção expressa garantia do interesse público uma vez que atende aos anseios do constituinte e diretrizes teórico normativas. Além disso, como se mostrará adiante, o arcabouço jurídico brasileiro consagra a remoção como exceção, havendo, portanto, o direito a não remoção e urbanização da favela como regra.

\subsection{Direito a não remoção: Limitação à atuação administrativa}

Visando a remoção de favelas erguidas em longo período de tempo sob justificativa do "interesse público" ou "utilidade pública", o Poder Público deve obediência à legalidade, impessoalidade, moralidade, publicidade e eficiência, pois se trata de ato administrativo, encontrando-se, assim, vinculado aos princípios que o regem.

$\mathrm{O}$ ato de remoção nos termos do ordenamento jurídico deve ser excepcional, assim, o presente trabalho irá sinalizar a necessidade de o ato observar as premissas teórico-normativas tratadas anteriormente e obediência rigorosa aos demais princípios e regras constitucionais.

Essa preocupação constitui a tônica da presente monografia uma vez que várias remoções no Município do Rio de Janeiro são determinadas sem que o referido ato administrativo sequer seja fundamentado ou motivado, representando assim, violação aos princípios analisados no item anterior e ao direito de não remoção.

\footnotetext{
46 VILHENA,Oscar apud Gustavo Binenbojm. Uma teoria do direito administrativo: direitos fundamentais, democracia e constitucionalização. pg.98.
} 
Um determinado ato administrativo não pode ser desprovido de motivo e finalidade. Em várias situações casas situadas em favelas são demolidas sem fundamento prévio $e$ sem que o Poder Público apresente projeto para localidade, demonstrando, portanto, ato desprovido de finalidade e motivo e ausência de publicidade. Além disso, em outras situações justificativas diferenciadas são apresentadas para o mesmo ato (remoção) não observando, assim, a moralidade que se exige da Administração Pública. ${ }^{47}$

Destarte, é preciso que Administração observe os princípios que vinculam sua atuação, não podendo atender interesses escusos em detrimento do direito a permanência dos moradores nas favelas. Tal direito possui amparo constitucional e infraconstitucional, a saber, direito à moradia, à cidade, função social e princípio da confiança, expressão da moralidade pública, e, ainda, encontra-se expressamente positivado na Constituição do Estado do Rio de Janeiro e na Lei Orgânica do Município.

\subsubsection{Princípio da confiança: amparo ao direito a não remoção das Comunidades}

O princípio da confiança não se circunscreve ao direito privado, mas é aplicado também na relação entre o Estado e o indivíduo. Quando verificada a expectativa legítima do jurisdicionado a administração pública deve manter os atos administrativos, podendo ser concretizado através da reparação pecuniária após a invalidação de tal ato perpetrado no tempo.

Embora o princípio não se encontre expressamente positivado no ordenamento jurídico brasileiro, pode ser extraído dos princípios que o regem, tal como o da boa-fé objetiva ${ }^{48}$ No âmbito do direito privado a boa-

\footnotetext{
${ }^{47}$ Entre as favelas que tiveram moradores removidos sem que a municipalidade apresentasse justificativa prévia destacam-se a Vila Autódromo e a denominada Favela da Galinha.

$48 \mathrm{O}$ presente trabalho não delineará a evolução histórica do conceito e sua aplicabilidade no direito privado restringindo-se apenas em breve estudo do princípio nos atos da administração pública, sem a pretensão de esgotar o estudo sobre o tema. Sobre o tema ver Valter Schuenquener de Araújo, O Princípio da Confiança: Uma nova forma de tutela do Cidadão diante do Estado.
} 
fé objetiva encontra-se positivada no artigo 442 do Código Civil brasileiro de $2002^{49}$, limitando a atuação dos contratantes e os impondo um padrão de conduta no sentido da cooperação, obrigando-os a manter boa-fé e probidade em todas as fases do contrato.

Assim, a boa-fé é a própria lei. Na seara do direito civil tem tríplice função, a saber, a de interpretação dos negócios jurídicos, de restrição da atuação dos contratantes, bem como imposição de deveres de cooperação (vide artigos 113, 422 e 187, todos do CC/2002). ${ }^{50}$

Um dos deveres impostos pelo referido princípio é a proibição de comportamentos contraditórios, ou seja, atuação posterior que se põe em contradição com comportamento anterior. Destarte, o princípio da boa-fé impõe um dever de coerência no comportamento.

Esta obrigação não encontra previsão expressa, mas alguns dispositivos normativos demonstram que o legislador repudia comportamentos contraditórios e desleais (vide artigos 175, 476, 491 e 1.146, todos do CC/2002), estando portando a vedação a condutas contraditórias inseridas na cláusula geral da boa-fé objetiva enunciada pelo art. 422 do $\mathrm{CC} / 2002$. Desse modo, o princípio da confiança, que veda comportamentos contraditórios, é irradiação do princípio da boa-fé. ${ }^{51}$

Cabe, outrossim, ponderar que apenas as legítimas expectativas impõem a aplicação do referido princípio, ou seja, aquelas pautadas em atos concretos que geraram na outra parte a confiança/expectativa de que a situação objetiva gerada se manteria no tempo.

Não obstante sedimentada aplicação no âmbito do direito privado, a boa-fé expandiu-se para outras áreas do direito, sendo aplicável inclusive no

\footnotetext{
49 O referido princípio encontra-se positivado também no Código de Defesa do Consumidor, de 1990 , nos artigos $4^{\circ}$, III, e 51, IV.

${ }^{50}$ NEGREIROS, Teresa. Fundamentos para uma nova interpretação constitucional do princípio da boa-fé. Rio de Janeiro: Renovar, 1998.

${ }^{51} \mathrm{O}$ venire contra factum proprium é a expressão que se refere vedação de comportamento contraditório.
} 
âmbito do direito público, ${ }^{52}$ reconhecida como princípio fundamental do Direito Internacional. ${ }^{53}$

Com advento do Estado de bem estar social, em contraposição ao Estado Liberal, quando o Estado assumiu o papel de agente fomentador da igualdade material e do desenvolvimento social vários institutos sofreram limitações objetivando a justiça social. ${ }^{54}$ Assim, a boa-fé deixou de ter caráter apenas privatista passando a percorrer todas as relações, inclusive a do Estado com o indivíduo visando à garantia do Estado Democrático de Direito que, além de assegurar os direitos e garantias fundamentais visa resguardar participação popular na gestão das políticas públicas.

Assim, em sua atuação, a Administração Pública deve pautar sua conduta de acordo com os princípios da boa-fé, uma vez que o Ente atua para garantia dos direitos fundamentais do jurisdicionado. Além disso, em contraponto ao caráter histórico do Estado que sempre exerceu um poder arbitrário e absoluto em relação aos cidadão, a ordem democrática impõe que a atuação do Estado esteja pautada na transparência e lealdade.

Canotilho afirma que a proteção da confiança é um elemento constitutivo do Estado de Direito e que encontra no mesmo patamar do princípio da legalidade da administração. $\mathrm{O}$ autor afirma que "O homem necessita de segurança para conduzir, planificar e conformar autónoma e responsavelmente a sua vida. Por isso, desde cedo se consideram os princípios da segurança jurídica e da proteção da confiança como elementos constitutivos do Estado de Direito." 55

Celso Antônio Bandeira de Mello afirma que o princípio da boa-fé, lealdade e confiança legítima tem aplicação em todos os ramos do direito e é aplicável, assim, em todas as esferas de atuação do Estado, a saber,

\footnotetext{
${ }^{52}$ GODOY, Claudio Luiz Bueno de. Função social do contrato. São Paulo: Saraiva 2004, pg. 100. ${ }^{53}$ MAZZUOLI, Valério de Oliveira. Curso de Direito Internacional Público, 3 ed. rev., atual. ampl. São Paulo: Revista dos Tribunais, 2008, pg. 113.

${ }^{54}$ Destaca-se a propriedade. A função social passou a integrar o conceito de tal instituto. E, ainda, a própria autonomia privada que não possui mais caráter absoluto.

${ }^{55}$ CANOTILHO, José Joaquim Gomes. Direito Constitucional. 7 ed. Coimbra: Livraria Almedina, 2000, p. 257.
} 
legislativo, executivo e judiciário. ${ }^{56}$ Destarte, a boa-fé objetiva e os princípios que a irradiam são aplicáveis no âmbito do direito administrativo.

$\mathrm{Na}$ seara do direito administrativo, o princípio da confiança possui três acepções, a saber, ligada as expectativas quanto ao procedimento administrativo; ressarcimento diante da frustação de legítimas expectativas e a manutenção de atos da administração pública ${ }^{57}$. Para Almiro do Couto e Silva, o princípio da confiança envolve, entre outros, a "responsabilidade do Estado por promessas feitas por seus agentes." ${ }^{\circ 8}$ No âmbito do STF e STJ é possível encontrar vários julgados que aplicam o princípio na relação entre o administrador público e administrado. ${ }^{59}$

Aplica-se o referido princípio nas relações entre o Poder Público e os particulares, devendo a conduta da Administração Pública estar pautada na confiança, lealdade e transparência visando a realização da justiça material e construção de uma sociedade livre, justa e solidária, objetivos fundamentais estabelecidos pelo constituinte (art. $3^{\circ} \mathrm{CRFB} / 88$ ).

$\mathrm{Na}$ esfera do direito administrativo o princípio da boa-fé tem previsão normativa nos artigos $2^{\circ}$, parágrafo único, $\mathrm{IV}^{60}$, e no art. $4^{\circ}$, inciso II da Lei $\mathrm{n}^{\circ}$ 9.784, de 29 de janeiro de 1999 (Lei de Processo Administrativa). Cita-se ainda a Lei n. 8.429/92 (Lei de Improbidade Administrativa) que estabelece o dever de lealdade e honestidade como parâmetro de ação do administrador público (art.11). Desse modo, a boa fé, positivada, e a confiança, extraída da boa-fé, configuram princípios de

\footnotetext{
56 MELLO, Celso Antônio bandeira de. Curso de Direito Administrativo. pg.

57 FAÇANHA ROCHA, Ludiana Carla Braga e Márcio Augusto de Vasconcelos Diniz. A Administração Pública e o Princípio da Confiança Legítima. Página 10. Disponível em $<$ http://www.egov.ufsc.br/portal/sites/default/files/anexos/32601-39843-1-PB.pdf $>$. Acesso em $: 14 / 09 / 2015$

${ }^{58}$ COUTO E SILVA, Almiro apud BINENBOJM, Gustavo. Uma teoria do direito administrativo: direitos fundamentais, democracia e constitucionalização. pg. 194

59 Cita-se STF: RE (M.C.) 2.900/RS, Rel. Min. Gilmar Mendes, julgado em 37/05/2003 (Informativo 310), e STJ: REsp 709.934/RJ, Rel. Min Humberto Martins, julgado em 21/06/2007. ${ }^{60}$ Lei n. 9784/99, artigo 2: “A Administração Pública obedecerá, dentre outros, aos princípios da legalidade, finalidade, motivação, razoabilidade, proporcionalidade, moralidade, ampla defesa, contraditório, segurança jurídica, interesse público e eficiência. Parágrafo único: Nos processos administrativos serão observados, entre outros, os critérios de: (...) IV - atuação segundo padrões éticos de probidade, decoro e boa-fé."
} 
direito administrativo que devem ser observados pela Administração Pública.

Alguns autores vinculam o aludido princípio à segurança jurídica e moralidade administrativa (art. 37, caput CRFB/88) uma vez que esta impõe o dever entre quem tem a competência administrativa e o conjunto da sociedade de agir com lealdade e honestidade. ${ }^{61}$ Nesse sentido, aplica-se a vedação ao venire contra factum proprium (conduta contraditória) na relação entre Estado e indivíduo, sendo este crucial para fundamentar o direito de permanência dos moradores de favelas erguidas e não questionadas durante longo período de tempo.

Em muitas situações o Poder Público, por decurso temporal longínquo $^{62}$, não questiona legalmente a presença de moradores em determinada área e nem atua com seu poder de polícia para a retirada da comunidade. A omissão desses entes atesta presença do instituto da supressio. A expressão verwirkung, também referida pela doutrina dos países latinos como supressio designa a "inadmissibilidade de um direito por seu retardamento desleal". ${ }^{63}$

A inércia prolongada das entidades federadas aliada, em diversas situações, com outorga de títulos de concessão de uso conferido pelo titular da área e com a cobrança de tributos incidentes sobre os imóveis geram legítimas expectativas aos moradores que permanecerão na localidade. Assim, aplicável ao caso à teoria do venire contra factum proprium que proíbe comportamento contraditório, tendo em vista o princípio da confiança.

Desse modo, o Estado não pode atuar contrariamente à conduta de omissão e chancela, muitas vezes através da cobrança de impostos e

\footnotetext{
${ }^{61}$ Nesse sentido cita-se Egon Bockmman Moreira, José Guilherme Giacomuzz e Juarez Freitas.

$62 \mathrm{O}$ presente estudo não analisará juridicamente a situação especifica de moradias erguidas a pouco tempo, mas comunidades que se expandiram- ao longo do tempo diante do descaso do poder público. A outra situação específica merece melhor análise envolvendo ainda a possibilidade de direito à indenização ou remanejamento, prioritariamente, tendo em vista o direito à moradia e função social da cidade e posse.

${ }^{63}$ SCHREIBER, Anderson. A proibição do comportamento contraditório. Tutela da confiança e venire contra factum proprium. Rio de Janeiro: Renovar, 2005. p. 178.
} 
concessão de direito real de uso, que geram aos moradores legítimas expectativas quanto à permanecia em determinada área. Emergindo a ideia legítima de manutenção do ato administrativo (omissão e chancela) cujo efeito prolongou-se no tempo, estabilizando a relação entre o administrado e o poder público. ${ }^{64}$

O princípio da confiança, expressão do princípio da boa-fé, combinado com as normas internacionais e nacionais que protegem o indivíduo contra desocupações forçadas, que serão referenciadas a seguir, garantem ao morador de comunidades erguidas em área pública o direito à permanência.

Ressalta-se ainda que os moradores das comunidades instalam suas residências na localidade desenvolvendo identidade com a área em questão atribuindo-lhe função social às áreas, muitas vezes abandonas e não atrativas ao poder público. Nesse sentido, é mister destacar que a política urbanística brasileira tutela aquele atribui função social à área em detrimento do próprio proprietário em situações de abandono, visto que a função social (art. 5, XXXII CRFB/88) é elemento constitutivo da propriedade.

\subsubsection{Função social da posse, da Cidade e Direito à Cidade.}

A política urbanística brasileira é fundada na função social da propriedade (art. $\left.5^{\circ}, \mathrm{XXXII} \mathrm{CRFB} / 88\right)^{65}$. Tal princípio possui natureza constitucional e é um dos elementos característicos das preocupações jurídicas do Constituinte de 1988. Nesse sentido, a propriedade deixa de

\footnotetext{
${ }^{64} \mathrm{O}$ direito possui vários mecanismos que visam estabilização das relações, entre eles cita-se a coisa julgada, o ato jurídico perfeito e direito adquirido.

${ }^{65} \mathrm{~A}$ função social da propriedade está prevista no artigo art. $5^{\circ}$, XXIII da Constituição da República Federativa do Brasil de 88. O princípio foi consagrado expressamente na Constituição Mexicana de 1917 e na Constituição de Weimar, em 1919.

${ }^{65}$ Artigo 153 da Constituição de Weimar.
} 
comportar pressupostos absolutos sendo sua concepção relativizada pela função social.

A propriedade é limitada por uma série de restrições de natureza privada, como o direito de vizinhança, ou de natureza pública, tal como o loteamento, zoneamento e uso e ocupação do solo. Nesse sentido, a função social do direito de propriedade imposto a partir de 1988, não é apenas um elemento que restringe os atributos inerentes à propriedade, a saber, uso, gozo e disposição, mas integra o próprio conceito de propriedade, obrigando assim, o proprietário utilizá-la de modo a alcançar sua função inserida na sociedade, pois "a propriedade obriga e o seu uso e exercício devem ao mesmo tempo representar uma função no interesse social"66.

O Constituinte de 1988 ao submeter o direito de propriedade à função social, justificando seus fins e utilização, objetiva que propriedade exerça função que transcenda interesse unicamente particular. Nos termos expressos no artigo $182 \S 2^{\circ}$ da CRFB/88, a propriedade urbana cumpre sua função social "quando atende às exigências fundamentais de ordenação da cidade expressas no plano diretor", assegurando, assim, "atendimento das necessidades dos cidadãos quanto à qualidade de vida, à justiça social e ao desenvolvimento das atividades econômicas" (art.7 da Lei Complementar 111/2011 - Plano Diretor da Cidade do Rio de Janeiro). ${ }^{67}$

Segundo Rosângela Cavallazi a função social do direito de propriedade "impõe o exercício do direito de propriedade, seja pública ou privada, segundo os interesses da coletividade, de forma condizente com as determinações do Plano diretor da Cidade, referência fundamental para atender as exigências da função social da cidade(...)". ${ }^{68}$ Desse modo, o direito de propriedade está condicionado ao atendimento da função da cidade.

\footnotetext{
${ }^{66}$ Artigo 153 da Constituição de Weimar.

${ }^{67}$ Quando a propriedade não cumpre sua função social seu titular pode sofrer sanções, tais como as previstas no $\$ 4^{\circ}$ do referido artigo e no artigo 183 da CRFB/88.

68 CAVAlLAZZI, Rosângela Lunardelli. O Estatuto Epistemológico do Direito Urbanístico Brasileiro: possibilidades e obstáculos na tutela do Direito à Cidade. In Direito da Cidade: novas concepções sobreas relações jurídicas no espaço social urbano. COUTINHO, Ronaldo e BONIZZATO, Luigi, orgs. Rio de Janeiro: Lúmen Júris, 2007. p.58.
} 
O ocupante do espaço urbano deve desenvolver suas atividades e exercer seu direito de propriedade visando atender seus próprios interesses e os interesses da coletividade, atribuindo, assim, função social a própria cidade. A realização da função social da cidade garante o direito a cidade sustentável, que pode ser entendido, nos termos do art. $2^{\circ}$ do Estatuto da Cidade "como o direito à terra urbana, à moradia, ao saneamento ambiental, à infraestrutura urbana, ao transporte e aos serviços públicos, ao trabalho e ao lazer, para as presentes e futuras gerações ”. Assim, Rosângela Cavallazi, define direito à cidade como um feixe de direitos sociais, sendo, portanto, "expressão do direito à dignidade da pessoa humana". ${ }^{69}$

O desenvolvimento da função social da cidade é de interesse de todos os habitantes da cidade, tendo em vista que todos, sejam moradores, comerciantes, turistas, trabalhadores são afetados pelas atividades desempenhadas na cidade. Assim, o pleno desenvolvimento das funções sociais da cidade é interesse metaindividual de seus habitantes visando o "bem-estar dos habitantes da cidade".70

$\mathrm{O}$ respeito à função social da cidade, garantia do direito à cidade aliada à função social da propriedade deve ser aplicado para resolução das questões urbanas, inclusive as que envolvem ocupações para fins de moradia das populações de baixa renda. A tutela do direito à moradia representa proteção de um dos feixes de direitos que compõe o direito à cidade. Para garantia de tal direito se impõe a funcionalização das atividades e usos da cidade.

Quando uma determinada área, ainda que pública, sem função social é ocupada para fins de moradia deve o direito de permanência dos mesmos ser tutelado uma vez que "a propriedade obriga e o seu uso e exercício

69 CAVALLAZZI, Rosângela Lunardelli. O Estatuto Epistemológico do Direito Urbanístico Brasileiro:possibilidades e obstáculos na tutela do Direito à Cidade. p.56. O conceito foi construído a partir do conceito do texto da Carta Mundial pelo Direito à Cidade.

${ }^{70}$ SAULE JÚNIOR, Nelson. A proteção jurídica da moradia nos assentamentos irregulares, Porto Alegre: Sergio Antonio Fabris Editor,2004. pgs.221/223 
devem ao mesmo tempo representar uma função no interesse social""71 e área improdutiva ou ociosa ${ }^{72}$ não cumpre função social.

É imperioso destacar que o Código Civil de 2002 consagra expressamente em vários dispositivos o princípio da função social da propriedade (v.g. art. 1228, parágrafos $1^{\circ}$ e $2^{\circ}$ ) e implicitamente da função social da posse (v.g. 1238 paragrafo único, 1242 parágrafo único e 1228 parágrafo 4).

O instituto jurídico da posse não se confunde com o da propriedade. $^{73}$ Entretanto o possuidor ao utilizar a coisa atribuindo-lhe função socioeconômica deve este ser tutelado mesmo contra o titular, quando este não atribuir função social ao bem. Sendo esse entendimento aplicável inclusive quando o titular é o Poder Público. Neste sentido é o posicionamento do Tribunal de Justiça do Rio de Janeiro, julgado em 13/12/2006:

Apelação. Ordinária. Concessão real de uso de bem público. Municipalidade que não deu função social à propriedade dominical sua e pretende desalijar família de baixa renda, que ocupou imóvel abandonado.

$$
[\cdots]
$$

Ausente a finalidade pública bem delimitada, é viável a permanência da apelada e sua família no imóvel, uma vez que, mantida a situação fática existente, estarse-ia, sem dúvida, cumprindo com a função social do imóvel. Como dito alhures, desnecessária a edição de medida de provisória com o fito de disciplinar a função social da propriedade, tendo em vista que esta goza de assento constitucional (arts. $5^{\circ}$, XXIII e 170, III, CRFB/88), e, repita-se, não dando a

\footnotetext{
71 Artigo 153 da Constituição de Weimar.

72 É importante salientar que uma determinada área pode não estar sendo utilizada economicamente, mas estar cumprindo sua função social. A título exemplificativo cita-se as áreas de preservação ambiental.

73 A distinção entre os dois institutos não serão as preocupações do presente estudo. Sobre o tema recomenda-se TORRES, Marcos Alcino de Azevedo, "Posse e Propriedade", Rio de Janeiro, Lumen Juris, 2006, p. 295-317.É importante destacar que existem posições doutrinárias divergentes que explicam o conceito de posse, tais como as posições clássicas de Savigny (teoria subjetiva da posse, que exige o animus domini) e Ihering (teoria objetiva, o qual a verificação da posse basta a "aparência de propriedade"). E ainda que existem vários institutos privatistas que tutelam o direito a posse, como as ações possessórias com previsão no Código Civil.
} 
municipalidade função social ao bem, este caracterizado como dominical, faz-se mister a chamada concessão de uso especial. Observando-se, contudo, que não se está conferindo o domínio, mas sim a posse do imóvel para o fim específico de moradia, estando o possuidor, que deu função social ao imóvel, sujeito à cassação da concessão do benefício, na hipótese de descumprimento dos requisitos e fins determinados. Recurso conhecido e desprovido. ${ }^{74}(2006.001 .44440 \quad$ APELAÇÃO DES. AZEVEDO PINTO - Julgamento: 13/12/2006 - DECIMA TERCEIRA CAMARA CIVEL)

(grifos atuais)

O respeito à função social da posse constitui proteção à dignidade humana de quem não possui propriedade, sem teto ou sem-terra ${ }^{75}$, ou de toda coletividade, quando o possuidor atribui função social à área ociosa ou abandonada ou com função antissocial a terra. Constitui, ainda, satisfação dos anseios do constituinte originário que exige funcionalização do patrimônio para atingir os objetivos do Estado, tais como erradicação da pobreza, desenvolvimento nacional, justiça e solidariedade. ${ }^{76}$

Desse modo, a tutela ao direito à permanência dos moradores das favelas, amparados pela função social da posse e princípio da confiança, representa atendimento de um dos critérios para realização da função social da cidade, e assim, garantia do núcleo central do direito à cidade, a saber, o direito à moradia adequada. Este é considerado o núcleo do direito à cidade uma vez que para garanti-la é necessário o respeito ao saneamento ambiental, transportes de qualidade, serviços públicos, entre outros.

\footnotetext{
74 Acordão do tribunal de Justiça do Estado do Rio de janeiro. Disponível em: $<$ http://www.urbanismo.mppr.mp.br/arquivos/File/TJRJCUEMfunosocialpropriedadepblica.pdf.> Acesso 21/09/2015.

75 AFONSIN, Jacques Távora. A função social da posse como pressuposto de licitude éticojurídico do acesso e da conservação do direito à terra. $\mathrm{Pg}$.181..Disponível em $<$ http://www.abda.com.br/revista18/pdf/artigos/A\%20fun\%C3\%A7\%C3\%A3o.pdf $>$ Acesso 10/10/2015.

${ }^{76} \mathrm{O}$ princípio da função social da posse possui respaldo nos dispositivos Constituição Federal que consagram a dignidade humana como fundamento do Estado, que se voltam à justiça material, a solidariedade e tutelam a moradia extraído estando compreendido no enunciado do art. 5 parágrafo 2 . Além disso, percebe-se que o legislador também tutela a posse ao reconhecer instrumentos que a legitimam a despeito do título de propriedade, tais como a usucapião, a concessão real de uso.
} 
Amparado pela Carta Maior e por normas internas e internacionais, irradiado pelo princípio da função social, o direito fundamental à moradia desdobra-se no direito a não remoção (proteção contra desocupações forçadas). Com efeito, a política urbanística brasileira, como expresso no subcapítulo seguinte, estabelece a prevalência da regularização fundiária e urbanísticas para pessoas de baixa renda visando, assim, construção de uma sociedade justa e solidária, protetora dos direitos fundamentais e da dignidade humana.

\subsubsection{Direito à moradia}

Conforme já mencionado o direito a não remoção é um desdobramento do direito à moradia consagrado no art. $6^{\circ}$ da Constituição da República Federativa do Brasil de 1988. A emenda constitucional 26/2000 elevou a direito a moradia ${ }^{77}$ ao de garantia fundamental cabendo ao Estado sua tutela e não sua restrição. Tal direito também é reconhecido por tratados e declarações internacionais de direitos humanos.

$\mathrm{O}$ direito à moradia adequada passou por um processo de normatização no âmbito internacional durante a década de 90, sendo reconhecido como direito humano A Declaração Universal dos Direitos Humanos de 1948 em seu artigo XXV, 1, consagrou o direito à habitação. Ainda o Pacto Internacional de Direitos Econômicos, Sociais e Culturais (ONU), este último ratificado pelo Brasil em 24 de abril de 1992 consubstanciado pelo Decreto 591 de 6 de julho de 1992, dispõe no seu art. 11 sobre o direito à moradia adequada.

Além dos instrumentos internacionais citados, o referido direito é reconhecido em vários tratados e declarações internacionais, tais como, Pacto Internacional de Direitos Sociais, Econômicos e Culturais de 1966, art.11-1; Convenção Internacional sobre a Eliminação de todas as Formas

\footnotetext{
77 Para melhor compreensão mais ampla do referido direito, ver SAULE JÚNIOR, Nelson. A proteção jurídica da moradia nos assentamentos irregulares, Porto Alegre: Sergio Antonio Fabris Editor, 2004.
} 
de Discriminação Racial de 1965, art.5- e, III; Declaração sobre Raça e Preconceito Racial de 1978, art.9-2; na Convenção sobre Eliminação de todas as Formas de Discriminação contra a Mulher de 1979, art.14-2, h; Convenção sobre os Direitos da Criança de 1989, art.27-3; Convenção dos Trabalhadores Imigrantes de 1990, art.43 e Convenção 169 da Organização Internacional do Trabalho sobre Povos Indígenas e Tribais de 1989, arts.13 a 19 , entre outros. ${ }^{78}$

O Comentário $\mathrm{n}^{\circ} 4$ do Comitê das Nações Unidades sobre os Direitos Econômicos, Sociais e Culturais, principal instrumento internacional para interpretação da moradia adequada previsto no artigo 11. ${ }^{\circ}$, n. $^{\mathrm{o}} 1$ da Convenção de Direitos Econômicos Sociais e Culturais (adotado na 6. ${ }^{\text {a }}$ sessão do Comité, 1991) define moradia adequada ressaltando a segurança da posse e adequação cultual como critérios necessários para sua garantia. ${ }^{79}$

A segurança da posse é fundamental para garantia do direito à moradia, pois sem tal segurança haverá sempre a iminência de deslocamento forçado, deixando, assim, os moradores em situação de risco constante. Para garanti-la é preciso que o Estado assegure o direito do indivíduo de permanecer em determinada localidade, seja por meio de normas que a tutelem ou através do reconhecimento das diversas formas de uso e ocupação do solo, tais como a concessão de uso especial pra fins de moradia, usucapião especial urbano e concessão de direito real de uso e zonas especiais de interesse social. ${ }^{80}$

\footnotetext{
${ }^{78}$ OSÓRIO, Letícia Marques. Direito à moradia adequada na América Latina. In: Direito à moradia e segurança da posse no Estatuto da Cidade: Diretrizes, instrumentos e processos de gestão. Betânia de Moraes Alfolsin, Edésio Fernandes .2 $2^{\circ}$ Triagem. Belo Horizonte: Forúm, 2006.p;32

${ }^{79}$ Comentário Geral n4.Disponível em $<$ http://www.unhchr.ch/tbs/doc.nsf/(Symbol)/469f4d91a9378221c12563ed0053547e?.Opendocum ent.> .O comentário contém vários preceitos que norteiam o direito à moradia ressaltando, entre outros, a interdependência do Direito à Moradia com os demais Direitos Humanos(sessão 7), a necessidade de medidas imediatas de proteção à Moradia (sessão 10, e, a Prioridade da Política Habitacional aos Grupos Vulneráveis( sessão 11).

${ }^{80}$ Para uma visão ampla sobre os instrumentos de proteção jurídica da posse nas favelas, ver SAULE JÚNIOR, Nelson. A proteção jurídica da moradia nos assentamentos irregulares. pgs. $375-435$.
} 
A moradia adequada não engloba apenas a estrutura física do espaço, "um teto e quatro paredes", mas abrange, entre outros fatores, a segurança física e estrutural do morador, proteção legal contra remoções forçadas e respeito a identidade cultural do habitante. Desse modo, as normas internacionais concebem a moradia adequada como direito essencial para a dignidade humana e exercício dos direitos econômicos, sociais, culturais e individuais, tais como o direito à vida e à liberdade.

Nelson Saule Júnior afirma que o direito à moradia só é plenamente satisfeito a partir da existência de três elementos, a saber: viver com segurança, com paz e com dignidade. O comando constitucional da dignidade da pessoa humana impõe que todas as pessoas tenham um padrão de vida digno, que engloba, entre outros, à moradia adequada. Estando o referido direito inter-relacionado com demais direitos humanos, como o direito à inviolabilidade de domicílio, segurança e meio ambiente saudável. ${ }^{81}$

Visando a garantia do direito à moradia adequada o Comentário $\mathrm{n}^{\mathrm{o}} 4$ do Comitê sobre os Direitos Econômicos, Sociais e Culturais considera à proteção contra desocupação forçada crucial para garantia do direito à moradia adequada. Desse modo, os Estados Partes devem adotar medidas para garantir segurança jurídica da posse. Considerando desocupações forçadas incompatíveis com o Pacto sendo justificáveis apenas em situações excepcionais.

No que tange a legislação interna o Estatuto da Cidade (Lei Federal $\mathrm{n}^{\mathrm{o}} 10.257$ de 2001) prevê expressamente o direito à moradia como integrante das políticas de desenvolvimento das funções sociais da cidade (art. $2^{\circ}$, I e II). Destaca-se ainda a Constituição do Estado do Rio de Janeiro o qual estabelece que no desenvolvimento da política urbana o Estado e Município devem "assegurar a urbanização, regularização fundiária e

${ }^{81}$ SAULE JÚNIOR, Nelson. A proteção jurídica da moradia nos assentamentos irregulares, Porto Alegre: Sergio Antônio Fabris Editor,2004. Pg135/136. 
titulação das áreas faveladas e de baixa renda, sem remoção dos moradores"( art. 234, I).

No mesmo, sentido cita-se o Plano diretor da Cidade do Rio de Janeiro, Lei Complementar n. ${ }^{o} 111$ de $1^{\circ}$ de fevereiro de 2011, que no âmbito do art. 3, inciso V estabelece a urbanização das favelas como crucial para o pleno desenvolvimento das funções sociais da cidade.

Do mesmo modo, a Lei Orgânica do Município do Rio de Janeiro reconhece o direito a moradia como essencial a função social da cidade (art. 422) e consagra o direito a não remoção sendo esta apenas admitida quando as condições físicas da área ocupada imponham risco de vida aos seus habitantes (art. 429).

Ainda assim, a referida norma determina que a política de desenvolvimento urbano nos casos excepcionais de remoção e remanejamento de população de baixa renda deve respeitar a "participação da comunidade interessada e das entidades representativas na análise e definição das soluções"( art. 429, VI, “c”) e o artigo 458 do mesmo dispositivo normativo determina que o poder público deve "garantir que as informações chegue a todos os cidadãos e dar condições para que estes possam discutir os projetos e participar de suas soluções".

Além de expressamente previsto na legislação interna, o direito de permanência dos moradores em determinada comunidade também está amparado pelo princípio da confiança, conforme delineado no tópico $1.2 .1 \mathrm{e}$ pelos princípios da função social da posse, da cidade e direito à cidade sucintamente considerados no tópico 1.2.2 do presente estudo.

Desse modo, visando a garantia da dignidade humana do indivíduo, o Estado deve tutelar direito à moradia adequada e não restringi-lo ou violálo. Bem como é preciso que proteja a segurança da posse e o direito à não remoção, só podendo remover o morador se e quando cumprida todas as exigências legais.

Além disso, tendo em vista a natureza jurídica do direito envolvido, a remoção não deve ser fundamentada em interesse público genérico, mas é 
preciso que ato seja expressa e previamente fundamentado especificamente e observe todos os preceitos teóricos normativos citados no presente capítulo, entre outros, e se e quando ocorrer deve ser garantido o direito à participação da comunidade interessada para análise do ato e definição de soluções e, ainda, assentamento em localidade próxima.

É preciso ressaltar que a remoção deve ser ato excepcional e cuja permanência e regularização constituem regra, entretanto as remoções das favelas cariocas revelam que este constitui regra e objetiva satisfazer projeto de cidade, tal como será delineado no capítulo seguinte. 


\section{Capítulo 2. "Cidade de negócios", megaeventos e política remocionista}

\subsection{Cidade-negócio e políticas segregacionistas}

A ocupação do espaço urbano brasileir'o é caracterizada pelo déficit habitacional, ineficiência de infraestrutura, poluição ao meio ambiente e ocupação predatória do espaço. Essa atual configuração é consequência de uma série de fatores históricos. Entre eles destacam-se a forma como se deu a libertação dos escravos - o qual foi concedida liberdade meramente formal sem dar-lhes nenhuma assistência material, não possuindo muitas outras alternativas, senão de ocuparem os grandes centros urbanos - aliada à política de incentivo a imigração. ${ }^{82}$

Outro fator foi à industrialização e a política nacionaldesenvolvimentista que intensificou os processos de urbanização associado à falta de política que incentivasse a fixação do homem no campo ${ }^{83} \mathrm{~A}$ existência de atividade especulativa e a inexistência de uma política habitacional que enfrente a questão urbana também são outros fatores responsáveis pela forma irregular que se processa o adensamento demográfico. ${ }^{84}$

Coligada à ocupação desordenada, a segregação sócio espacial é outra consequência dos fatores supramencionados. As classes menos abastadas são "expulsadas" para periferias da cidade em decorrência do elevado custo de vida em determina região ou ocupam áreas de periferia situadas nas áreas centrais da cidade, onde vivem em condições precárias de vida, agravadas pela carência de infraestrutura e ausência regularização fundiária.

\footnotetext{
${ }^{82}$ LIRA, Ricardo Pereira. Direito Formal e direito Informal nos Centros Urbanos. Disponível em: $<$ http://www.e-publicacoes.uerj.br/index.php/rdc/article/viewFile/16963/12760>. Acesso em $12 / 09 / 2015$

${ }^{83}$ Ibid. Acesso em 12/09/2015.

${ }^{84}$ LIRA, Ricardo Pereira. Direito Urbanístico, Estatuto da Cidade e Regularização Fundiária. in COUTINHO e BONIZZATO. Op Cit. p.2
} 
Não obstante seja esse o cenário urbano brasileiro, existem vários instrumentos urbanísticos, tais como o direito de superfície, a concessão real de uso, imposto predial progressivo, usucapião especial urbano, a concessão de uso especial para fins de moradia, entre outros, e ainda vários princípios e premissas teórico normativas, algumas delineadas no capítulo anterior, que guiam a atuação administrativa para elaboração e execução de uma política urbanística democrática, justa e garantidora dos direitos fundamentais.

Entretanto várias das premissas normativas carecem de efetividade tendo em vista a falta de vontade política associada ao projeto de cidade inserido na lógica da sociedade de mercado. ${ }^{85}$ A política urbana brasileira pautou-se em um projeto de "elitização" e "mercantilização" da cidade objetivando a garantia de interesses de determinados grupos econômicos.

No Rio de Janeiro, a reforma urbana idealizada e realizada pelo prefeito Francisco Pereira Passos entre 1902 e 1906 visava reformar a aparência da capital de acordo com moldes franceses rompendo com aspectos caraterísticos da época colonial. A implementação da reforma no período resultou na ocupação de morros ${ }^{86}$ e várias remoções forçadas. ${ }^{87}$

Costas e Arguelhes, ao tratar das intervenções urbanas da Paris do século XIX e do Rio de Janeiro, destaca que objetivo era manipular e retirar dos habitantes a "possibilidade de escolha e de autodeterminação", in verbis:

\footnotetext{
${ }^{85} \mathrm{O}$ capítulo seguinte demonstrará a ausência de efetividade de alguns dos princípios tratados no capítulo anterior no caso da Vila Autódromo. Sobre a ausência de efetividade do princípio da gestão democrática da cidade no Parceria Publico Privada "Porto Maravilha", recomenda-se a leitura do relatório de pesquisa intitulado "Função Social da Cidade e Gestão Democrática Urbana: Estudo do "Projeto Porto Maravilha". Disponível em $<$ http://www.pucrio.br/pibic/relatorio_resumo2013/relatorios_pdf/ccs/DIR/DIR-Rebeca\%20Peterli.pdf.> Acesso em 26/09/2015.

${ }^{86}$ Para abrir a Avenida Central (atual Rio Branco), as Avenidas Francisco Bicalho e Rodrigues Alves foram demolidos cortiços, estalagens, armazéns, forçando grande parte da população que vivia no local a deslocar-se para subúrbios ou para os morros próximo à localidade.

87 Remoções na Vila Autódromo expõem o lado $B$ das Olimpíadas do Rio. Disponível em $<$ http://brasil.elpais.com/brasil/2015/06/20/politica/1434753946_363539.html>, Acesso em $13 / 09 / 2015$.
} 
“[...]A lógica racional e simétrica de uma cidade planejada manifesta tudo de modo muito objetivo, quer mostrar sua real intenção de ordenar, dividir, separar, segregar, agregar, estabelecer lugares e disposições aos seus habitantes, tentando manipulá-los cotidianamente. O planejamento parece querer tirar de seus habitantes toda e qualquer possibilidade de escolha e de autodeterminação, e dá lugar a uma cidade dominadora e autoritária. O projeto de uma nova cidade busca definir usos e sentidos, mas, de acordo com Michel de Certeau, ainda não é a cidade, pois esta somente existe em um espaço ocupado de vivências, experiências e relações de seus habitantes." 88

Assim, tal política de estruturação do espaço é utilizada para beneficiar determinadas classes e grupos econômicos - imobiliários, turísticos, gastronômicos, culturais - e para o exercício do controle social. Não obstante os trabalhos de Michel Foucault não terem por objeto especificamente o exercício do poder para construção da cidade mercantilizada e elitista , as considerações sobre disciplina, controle social e biopoder auxiliam na compreensão da política que norteia a produção do espaço urbano. Assim, as ações do Poder Público conduziram e conduzem condutas disciplinadas na cidade.

Entre as políticas que disciplinam comportamentos no espaço urbanos destacam-se as políticas remocionistas. Na dissertação de mestrado intitulada "Remoções biopolíticas: o habitar e a resistência da Vila Autódromo", Clarissa Naback associa a política de remoções como mecanismo de exercício de poder sobre as cidades. Segundo a pesquisadora "o deslocamento forçado e o reassentamento consistem em 'forma de governar' os moradores da favela" ${ }^{99}$. Nesse sentido, Alexandre Magalhães em sua tese conclui que as políticas remocionistas integram mecanismos de

\footnotetext{
${ }^{88}$ COSTA, A. C. S. \& ARGUELHES, D. O. apud LIMA DA SILVA, Diego de Toledo.. Históricas e atuais práticas de higienização social. Disponível em $<$ http://racismoambiental.net.br/2013/01/19/historicas-e-atuais-praticas-de-higienizacao-social/> Acesso em 26/09/2015.

${ }^{89}$ NABACK, Clarissa Pires de Alemida. Remoções biopoliticas : o habitar e a resistência da Vila Autódromo. Dissertação de Mestrado ( Direito). Puc. p. 63.
} 
controle dos moradores das favelas "que impulsionam ou reduzem determinados fluxos no meio urbano"..$^{90}$

Entretanto é mister ressaltar que muitas políticas públicas objetivam o exercício do controle social, mas a finalidade última é a satisfação de interesses de determinados grupos econômicos e sociais inseridos na lógica do modelo de produção vigente no período. Existe, assim, além do exercício do controle social, a ambição de tornar o espaço urbano um produto lucrativo para satisfação de determinados interesses.

Tal ambição está inserida na lógica da sociedade de mercado e do modo de produção capitalista. Negri e Hardt associam o capitalismo ao "contínuo movimento" de privatização das terras comuns e transferência das riquezas públicas para as mãos privadas ${ }^{91}$. Segundo os autores citados o capitalismo caracteriza-se, entre outros, pelo fato dos particulares apropriarem-se dos bens públicos, seja a água, o ar, os serviços públicos e inclusive espaços da cidade. Destarte, no modo de produção capitalista são utilizados espaço da cidade, reiteradas vezes, para atender exclusivamente interesses de determinados grupos econômicos.

Inserido na lógica da sociedade de mercado o espaço torna-se objeto de compra e venda e das estratégias que visam impulsionar a acumulação de capital. ${ }^{92}$ O Poder Público, no contexto do referido modo de produção, passa a gerenciar a cidade como se administra uma empresa, assim, o espaço urbano passa a ser visto como cidade-mercadoria. Nesse sentido, a

\footnotetext{
90 MAGALHÃES, Alexandre. Transformações no "problema favela" e a reatualização da remoção no Rio de Janeiro. Tese de Doutorado - Sociologia. Universidade do Estado do Rio de Janeiro,2013.

${ }^{91}$ NEGRI e HARDT apud. MENDES, Alexandre F. A Atualidade do Comunismo. A produção do comum no pensamento político de Toni Negri. pg. 12. É crucial mencionar que a teoria desenvolvida por Negri é complexa e não será objeto de análise deste presente estudo. $\mathrm{O}$ artigo de Alexandre Mendes pontua várias produções de Negri que podem auxiliar na compreensão da teoria desenvolvida pelo autor italiano.

${ }^{92}$ COUTINHO, Ronaldo. A mitologia da Cidade sustentável no Capitalismo. COUTINHO, Ronaldo e BONIZZATO, Luigi, orgs. Direito à Cidade: Novas Concepções obre as Relações Jurídicas no Espaço Social. Rio de Janeiro: Lúmen Júris, 2007.p.13
} 
cidade é inserida no mercado precisando ser valorizada e vendida como produto atraente e flexível. ${ }^{93}$

A associação que se faz à cidade-empresa está intrinsicamente ligada ao processo social em curso, pois, segundo Rosélia Piquet "o comportamento empresarial é determinado pelo conjunto das relações sociais de um dado momento histórico e pelas condições gerais de produção". ${ }^{94}$ A referida autora afirma que as moradias, escolas, hospitais e demais equipamentos coletivos pertencem a empresa que exerce o controle e influencia sobre as pessoas. Nesse contexto, o espaço urbano submete-se cada vez mais as demandas do mercado imobiliário e aos interesses do grande capital.

A “cidade negócios" é planejada pelo marketing urbano (city marketing) cujo objetivo é criar uma imagem positiva de determinado espaço. Desse modo, visando tornar a cidade uma "empresa" atraente políticas que visam "embelezar" o espaço urbano são frequentes. Tais como as políticas atuais de revitalização ${ }^{95}$ e outras implantadas em diferentes períodos da história brasileira, como a já citada, reforma "Pereira Passos".

A imagem urbana mercantilizada atrai visitantes, turistas, consumidores (internos e externos), habitantes, e, ainda, possibilita a atração de investimentos e capital. O poder público passa enxergar a cidade como "produto exportável e consumivel" que precisa ser "vendido". Nesse contexto, a cidade é gerenciada como uma empresa e por empresa. Competitividade, produtividade e submissão dos fins à logica mercadológica integram a gestão e planejamento urbano.

A cidade passa a ser concebida como empresa, que atua na lógica estratégica da sociedade de mercado e a ser vista como "mercadoria",

\footnotetext{
93 VAINER, Carlos B. Pátria, empresa e mercadoria. Notas sobre a estratégia discursiva do Planejamento Estratégico Urbano. In: ARANTES, Otília; VAINER, Carlos B. e MARICATO, Ermínia. A cidade do pensamento único: desmanchando consensos. Petrópolis, RJ: Vozes, 2000. p. 78.

94 PIQUET, Rosélia. Cidade-empresa : Presença na Paisagem urbana brasileira. Rio de Janeiro:Jorge Zahar Editor,1998.p 4.

${ }_{95}$ Nesse sentido destacam-se a revitalização da Zona Portuária do Rio de Janeiro e da Barra da Tijuca.
} 
conforme já mencionado, atraente e flexível. Mas não se trata a cidade apenas de uma mercadoria, mas segundo Vainer, é "uma mercadoria, mas também, e, sobretudo, uma mercadoria de luxo, destinada a um grupo de elite de potenciais compradores: capital internacional, visitantes e usuários solváveis". 96

A analogia à cidade-empresa ou cidade-mercadoria não reduz o seu conteúdo apenas à proposta administrativa, mas também redefine o poder que é exercido no espaço urbano. Vanier afirma que o conceito de cidade, e desse modo, os conceitos de poder público e de governo da cidade são resssiginificados que "tem como um dos esteios a transformação da cidade em sujeito/ator econômico ...e, mais especificamente, num sujeito/ator cuja natureza mercantil e empresarial instaura o poder de uma nova lógica, com a qual se pretende legitimar a apropriação direta dos instrumentos de poder público por grupos empresariais privados". 97

Conforme já mencionado, a sociedade de mercado impulsiona determinadas políticas públicas, como as remocionistas, para atender os "anseios dos negócios", como venda da imagem de um espaço urbano seguro e elitizado e assim, atrair setores econômicos-turístico, gastronômicos, por hipótese, e satisfazer os interesses imobiliários e das classes sociais dominantes.

Vainer afirma que esse projeto de cidade-mercadoria implica a direta e imediata "apropriação da cidade por interesses empresariais globalizados, e depende, em grande medida, do banimento da política e da eliminação do conflito e das condições de exercício da cidadania." 98

Conceitos que evidenciam "city marketing”, transformação da cidade em "mercadoria”, “empresa”, "elitização e mercantilização do espaço urbano" são relativamente contemporâneos e estão inseridos no

\footnotetext{
96 VAINER, Carlos B. Pátria, empresa e mercadoria. Notas sobre a estratégia discursiva do Planejamento Estratégico Urbano. In: ARANTES, Otília; VAINER, Carlos B. e MARICATO, Ermínia. A cidade do pensamento único: desmanchando consensos. Petrópolis, RJ: Vozes, 2000. p. 83 .

${ }^{97}$ Ibid. p.89.

${ }^{98}$ Ibid. p. 78.
} 
contexto da sociedade de mercado globalizada, entretanto algumas dessas são práticas antigas na história brasileira, visíveis em determinados períodos históricos e modelos de produção.

Diversas políticas foram adotadas visando o "embelezamento" do espaço urbano para tornar a imagem "consumível” e “exportável”, objetivando, assim, beneficiar determinados grupos econômicos - como latifundiários ou setores imobiliários - e para exercício do controle social.

Segundo o historiador Luiz Antônio Simas a política de higienização é mais antiga e remonta a libertação dos escravos e a política de estímulo a imigração branca. O historiador utiliza o vocábulo com outro significado associado à política para "branqueamento" da população. Entretanto, assim como as políticas de remoções forçadas e gentrificação - será mencionada mais adiante, a "higienização" tratada pelo historiador estava associada à classe social marginalizada e visava à elitização do espaço. ${ }^{99}$

Além de políticas expressamente segregacionistas, o Poder Público adotou medidas urbanas visando beneficiar determinados grupos sociais e o capital imobiliário, acentuando, assim, a segregação. No período de 1968 a 1973, somente no Estado do Rio de Janeiro, foram removidos mais de 175 mil moradores de 62 favelas, sobretudo durante o governo do então governador do Estado da Guanabara, Carlos Lacerda, ${ }^{100}$ cuja política remocionista tinha objetivo a mercantilização da cidade, visto que construtoras e políticos tinham interesses na "desfavelização" de determinadas áreas da cidade. ${ }^{101}$

A política de remoções forçadas continua após o golpe militar, passando reassentar os moradores em conjuntos habitacionais financiados

\footnotetext{
${ }^{99}$ LIMA DA SILVA, Diego de Toledo. Apud Luiz Antônio Simas. Históricas e atuais práticas de higienização social. Disponível em <http://racismoambiental.net.br/2013/01/19/historicas-eatuais-praticas-de-higienizacao-social/>. Acesso em 26/09/2015.

${ }^{100}$ BRUM, Mario Sergio. Mémorias da Remoção: $O$ incêndio da praia do Pinto e a "culpa" do governo.

Disponível em: $<$ http://www.encontro2012.historiaoral.org.br/resources/anais/3/1339790201_ARQUIVO_Me moriasdaRemocaoABHO2012.pdf $\wedge^{\wedge}>$. Acesso em 26/09/2015.

${ }^{101}$ RIBEIRO, Paula Paiva. Em entrevista a Publica. Ponha-se na Rua: Há 200 anos é assim que o governo lida com as comunidades cariocas. Disponível em $:<$ file://C:/Users/raquel/Downloads/ponha-se-na-rua-mais-de-200-anos-de-remocoescompulsorias-rio-de-janeiro.pdf.> Acesso em 18/09/2015.
} 
pelo Banco Nacional de Habitação. Nesse período grande partes das favelas removidas no Rio de Janeiro situavam-se na Zona Sul da cidade, como a favela da Catacumba, situada às margens da Lagoa Rodrigo de Freitas. ${ }^{102}$ Segundo Ricardo Pereira Lira a remoção da referida favela ocorreu para que "pudessem ser efetivadas, nos arredores, as suntuosas incorporações de vários edificios residenciais de altíssimo lucro, a serem ocupados pela alta classe média". ${ }^{103}$

Outro caso é o "desfavelamento" do munícipio de Sorocaba, São Paulo, no final da década de 90, que buscava "embelezar a cidade". Tal medida promoveu a segregação dos moradores do bairro Ana Paula Eleutério e revelou a maior preocupação com setor econômico e especulação imobiliária. ${ }^{104}$

Muitas das políticas urbanísticas brasileiras, tais como as anteriormente citadas, ampliaram a segregação sócio espacial e favoreceram determinados grupos. Assim, o crescimento das cidades brasileiras se deu baseado na retenção especulativa do espaço urbano e proporcionando lucros a determinados setores imobiliários.

A gentrificação é outra consequência possível de muitas políticas urbanas, que geram a valorização imobiliária de determinada localidade, que agrava a segregação sócio espacial. O vocábulo gentrification foi utilizado pela socióloga Ruth Glass ${ }^{105}$ na década de 60 ao estudar as transformações imobiliárias dos subúrbios londrinos. Com o passar do tempo outros autores utilizavam o termo descrevendo um processo social,

\footnotetext{
102 NABACK, Clarissa Pires de Almeida apud Rafael Gonçalves .Remoções biopoliticas : o habitar e a resistência da Vila Autódromo. p. 63.

103 LIRA, Ricardo Pereira. Direito Urbanístico, Direito Urbanístico, Estatuto da Cidade e Regularização Fundiária. COUTINHO, Ronaldo e BONIZZATO, Luigi, orgs.Direito à Cidade: Novas Concepções obre as Relações Jurídicas no Espaço Social. Rio de Janeiro: Lúmen Júris, 2007.p.13

104 LIMA DA SILVA, Diego de Toledo. Apud Pereira. Históricas e atuais práticas de higienização social. Disponível em:< http://racismoambiental.net.br/2013/01/19/historicas-eatuais-praticas-de-higienizacao-social/> acesso em 26/09/2015

105 GLASS, Ruth. London: Aspects of change. Centre for Urban Studies and MacGibbonand Kee, London. 1964, p. 20.
} 
econômico e cultural ${ }^{106}$. O geógrafo Neil Smith $^{107}$ foi dos autores que se debruçou sobre o estudo do processo de gentrificação.

O vocábulo é utilizado para definir o fenômeno da a "expulsão" de vários moradores tradicionais, que habitavam em determinada região ou bairro quando degradada ou desvalorizada, em decorrência de medidas que valorizam o espaço urbano e aumentam o custo de vida na região. Assim, o aumento do custo de vida, acarreta a substituição dos segmentos sociais menos abastados por outros.

O Poder Público ${ }^{108}$ não tem adotado medidas para conter a segregação decorrente da valorização do espaço. No contexto dos megaeventos o processo de gentrificação é acelerado em áreas que recebem investimentos públicos em infraestrutura, nesse sentido, destacam-se as áreas da Barra da tijuca e da Região Portuária do Rio de Janeiro.

Além de não adotar medidas para conter o processo de segregação sócio espacial, o Poder Público adota políticas urbanísticas que a intensificam visando beneficiar determinadas classes e grupos econômicos e ampliam tal segregação. Dentre essas medidas destacam-se as remoções de favelas erguidas a longo período de tempo, algumas já tratadas.

\subsection{Política de elitização e mercantilização na cidade do Rio de Janeiro no contexto dos megaeventos.}

Conforme já mencionado a política de elitização e mercantilização do espaço urbano através das remoções da comunidade cariocas ocorreu, entre outros períodos, durante a gestão do Prefeito Pereira Passos, no início no século XIX, e do governador Carlos Lacerda, no final da década de 60 e

\footnotetext{
${ }^{106}$ HAMNET, 1984 apud BIDOU ZACHARIANSEN (org), De volta à cidade: dos processos de gentrificação às políticas de "revitalização" dos centros urbanos. São Paulo. 2006, p.23. O autor definiu a gentrificação como um processo físico, econômico, social e cultural . Afirmando que é uma " mudança econômica sobre os mercados imobiliários e fundiários".

${ }^{107}$ Neil Smith estudou vários processos de gentrificação, com especial destaque para aquelas que ocorreram em bairros de Nova York.

108 Não obstante a expressão ser genérica o estudo refere-se ao poder público brasileiro , com destaque para o executivo, mas especificamente o carioca.
} 
início da de 70. Atualmente, no contexto dos megaeventos, várias comunidades situadas no território brasileiro estão sendo removidas ou ameaçadas de remoção.

Raquel Rolnik ao observar a vasta experiência internacional afirma que as execuções dos projetos para os megaeventos causam transgressões aos direitos humanos, sendo frequente violações ao direito à moradia através de remoções forçadas para ceder espaço à infraestrutura à renovação urbana.

A referida autora afirma ainda que as remoções são "medidas adotadas pelas autoridades para eliminar rapidamente favelas consideradas esteticamente negativas das áreas frequentadas pelos visitantes, medidas adotadas pelas autoridades para eliminar rapidamente favelas consideradas esteticamente negativas das áreas frequentadas pelos visitantes". Nesse contexto, determinados grupos imobiliários e sociais são beneficiados em detrimento dos moradores ${ }^{109}$

No Brasil a violação as normas constitucionais no contexto dos grandes eventos também é evidente. O Dossiê da Articulação Nacional dos Comitês Populares da Copa destaca violação ao direito à moradia através das remoções forçadas. Afirmam que ações comandadas pelo Poder Público Municipal, com apoio Estadual e, em alguns casos, Federal, tem por objetivo a retirada de moradias vidando "limpar o terreno para grandes projetos imobiliários com fins comerciais". 110

Trata-se, em regra, da remoção de comunidades situadas em localidades que tiveram grande valorização e, portanto, passam a ser objeto de interesse de determinados grupos econômicos. Os motivos alegados pelo poder Público para remoção das comunidades, evidentemente, não estão

\footnotetext{
109 Informe da Relatora Especial sobre moradia adequada disponível em https://raquelrolnik.files.wordpress.com/2010/11/mega_eventos_portugues $1 . p d f, \quad$ acesso em $30 / 09 / 2015$. No referido informe a relatora também cita exemplos de cidades que utilizaram os megaeventos para criação de infraestrutura com fins de melhoria da moradia, transportes e meio ambiente.

110 DOSSIÊ DA ARTICULAÇÃO NACIONAL DOS COMITÊS POPULARES DA COPA. Megaeventos e Violação de Direitos Humanos no Brasil. Disponível em:< http://www.apublica.org/wp-content/uploads/2012/01/DossieViolacoesCopa.pdf $>$, Acesso 28 de setembro de 2015.
} 
relacionados à mercantilização do terreno. São citadas entre outras justificativas o rico de vida - por supostamente estarem localizadas em áreas de risco - e interesse público para modificação do espaço.

No Rio de Janeiro, grande parte das atuais remoções, estão relacionadas às obras de infraestrutura para os megaeventos. O Dossiê elaborado pelo Comitê Popular da Copa e Olímpiadas do Rio de Janeiro afirma que a ocasião acelerou "a "limpeza social" de áreas valorizadas da cidade, e acelerou a abertura de novas frentes lucrativas para empreendimentos de alto padrão". Afirma ainda que se trata de "uma política de relocalização dos pobres na cidade a serviço de interesses imobiliários e oportunidades de negócios, acompanhada de ações violentas e ilegais."111

Além da preocupação popular com a violação ao direito à moradia e a permanência dos moradores especialistas também demonstram inquietação. Nesse sentido destaca-se a já citada Raquel Rolnik, que sinaliza as violações de direitos humanos que ocorrem para implantação dos megaeventos no Brasil. ${ }^{112}$ Rolnik, afirma que as obras realizadas no contexto megaeventos, em outras experiências, resultaram em "operações de 'limpeza' contra a população sem-teto ${ }^{113}$ " e no Brasil a experiência é similar gerando violação ao direito à moradia adequada.

A autora, no período em que exercia a função de relatora da ONU sobre moradia adequada, recebeu várias denuncias que sinalizavam violações às normas nacionais e internacionais de proteção dos direitos humanos nos processos de remoções. Segundo texto publicado no site das Nações Unidas do Brasil nessas situações, "os moradores não foram

\footnotetext{
${ }^{111}$ Dossiê do Comitê Popular da Copa e Olímpiadas do Rio de Janeiro. Megaeventos e violação de direitos humanos no Rio de Janeiro. Junho de 2014. P. 19. Disponível em < https://comitepopulario.files.wordpress.com/2014/06/dossiecomiterio2014_web.pdf $>$, acesso em28/09/2015.

${ }^{112}$ Eventos esportivos no Brasil ameaçam direito à moradia, diz relatora da ONU. Disponível em: $<\mathrm{http}$ //nacoesunidas.org/eventos-esportivos-no-brasil-ameacam-direito-a-moradia-diz-relatora-daonu/>.Acesso em 13/09/2015.

${ }^{113}$ ROLNIK, Raquel. Eventos esportivos no Brasil ameaçam direito à moradia. Diponível em:< http://nacoesunidas.org/eventos-esportivos-no-brasil-ameacam-direito-a-moradia-diz-relatora-daonu/>;Acesso em 04/10/2015.
} 
consultados e não tiveram a oportunidade de participar nas decisões que têm um sério impacto em seus padrões de vida". ${ }^{114}$

Muitos moradores das áreas afetadas questionam as remoções para a implementação do projeto e pontuam da falta da publicidade, transparência nas ações do Poder público e participação dos moradores afetados. ${ }^{115}$ Rolnik explicita ainda que muitos grupos imobiliários são beneficiados em detrimento da própria cidade que permanece insustentável. Segundo a relatora, em outubro de 2011:

“A Copa de 2014 em si é o que menos conta nessa história toda. A questão fundamental é como os grandes negócios imobiliários se aproveitam dessa onda em torno do megaevento para poder encaçapar a bola.

$[\ldots]$

A idéia de construir espaços públicos generosos, de qualificar o espaço urbano, expressas no plano diretor vão ficando para as cucuias... o que importa mesmo é quantos metros quadrados de área construída podem ser lançados no tempo mais curto possível.

Enquanto isso, nós continuamos a viver numa cidade entupida, desqualificada e insustentável. E parece que isso não é problema nem do poder público nem do setor imobiliário."116

Assim, observa-se que os megaeventos esportivos na cidade do Rio de Janeiro marcaram o retorno da política de "elitização" do espaço e "mercantilização" da cidade, através da violação do direito à moradia e de outras regras e princípios que determinam o modo de atuação da Administração Pública. ${ }^{117}$ Com a preparação para os eventos o Rio de

\footnotetext{
${ }_{114}$ Rolnik, Raquel. Eventos esportivos no Brasil ameaçam direito à moradia. Diponível em:< $\mathrm{http}$ ://nacoesunidas.org/eventos-esportivos-no-brasil-ameacam-direito-a-moradia-diz-relatora-daonu/>;Acesso em 04/10/2015.

${ }^{115}$ Relato dos moradores em reuniões no NUTH.

${ }^{116}$ ROLNIK, Raquel. Estádios e negócios imobiliários: já perdi a conta de em que capitulo está essa novela ...Disponível em <https://raquelrolnik.wordpress.com/2011/10/28/estadios-e-negociosimobiliarios-ja-perdi-a-conta-de-em-que-capitulo-esta-essa-novela/\#comments $>$. Acesso em 28/09/2015.

117 O Dossiê do Comitê Popular da Copa e Olímpiadas do Rio de Janeiro pontua várias ilegalidades que ocorreram no Rio de Janeiro para implementação dos megaeventos.
} 
Janeiro encontrou espaço para intensificar a implementação dos projetos visando à satisfação de modelo de "cidade negócios".

Assim, política de elitização e mercantilização do espaço urbano, pode ser observada nos últimos anos em consequência do Brasil, mais especificamente o Rio de Janeiro, atrair olhares internacionais, sobretudo pelos grandes eventos que ocorreram e ocorrerão no país.

O Pan Americano em 2007, a Rio + 20, em 2012, Copa do Mundo ocorrida em 2014 e as Olimpíadas que ocorrerá em 2016, acarretaram a necessidade de modificar e produzir espaço necessário para a realização dos mesmos, ocasionando, assim, remoções para reformulação do espaço e atendimento das demandas do capital.

Entre as comunidades situadas no Rio de Janeiro que foram alvo das remoções em função dos megaeventos ${ }^{118}$, destaca-se a denominada Vila Autódromo, localizada em pequena faixa da terra Península de Itapeba, ao extremo norte da Barra da Tijuca, bairro caraterizado por atrair olhares do capital e que irá abrigar Vila Olímpica em função dos jogos de 2016.

118 O Dossiê elaborado pelo Comitê Popular da Copa e das Olímpiadas sinalizou as violações de direitos humanos no Rio de Janeiro em função da Copa e das Olimpíadas. O documento destaca as Comunidades que tem sido alvo de remoções forçadas. Disponível em https://comitepopulario.files.wordpress.com/2014/06/dossiecomiterio2014_web.pdf. Entretanto é importante mencionar que a remoção da Vila Autódromo é pretensão do Poder Público antes dos megaeventos. 


\section{Capítulo 3. Análise da justificativa do Poder Público sob a ótica dos Princípios Constitucionais e do Direito de Permanência}

\subsection{Vila Autódromo: formação, titulação e remoção}

A Vila Autódromo por volta de 1960 reunia colônia de pescadores, entretanto a omissão do Poder Público fez com que a comunidade se expandisse e que a Lagoa de Jacarepaguá, que beirava a localidade, se tornasse local de despejo de esgoto não tratado, acabando com a exploração da atividade pesqueira na área.

O descaso Municipal em relação ao saneamento básico da Zona Oeste não impediu que a comunidade ampliasse e que os moradores pudessem realizar outras atividades econômicas. Com a construção do Autódromo Nelson Piquet, a ocupação passou a se concentrar na faixa estreita de terra entre o autódromo e a Lagoa de Jacarepaguá, abrigando operários, famílias removidas de outras comunidades, funcionários públicos e trabalhadores de condomínios próximos da localidade, entre outros.

Em 1993 o Estado do Rio de Janeiro iniciou processo de regularização fundiária da área (Processo administrativo $n^{0}$ E28/001057/93) ${ }^{119}$ que culminou na outorga de termos de concessão de uso em favor dos moradores daquela região, publicado no diário oficial em abril de 1994 e, posteriormente em 1998. O referido título concedeu a posse do terreno onde estava construída as respectivas residências por 99 (noventa e nove) anos, renovável por igual período, aos moradores e suas famílias para que possam vir a ter garantido o direito à moradia.

Não obstante a expansão da Vila Autódromo, em 1993 o Município ingressou em juízo pleiteando a demolição dos imóveis dos ocupantes da

119 Em 1992, a Secretária de Estado de Assuntos Fundiários, que substitui a Secretaria Extraordinária de Assuntos fundiários e Assentamentos humanos (SEAF) iniciou cadastramento dos moradores com objetivo de dar início a regularização fundiária da Comunidade (proc.0081973-19.1993.8.19.0001, extraídas de fls. 62/71 e 77). 
Vila Autódromo ${ }^{120}$ afirmando que esta causaria dano ambiental, estético, paisagístico e turístico. No entanto, a sentença proferida em setembro de 2011, julgou parcialmente procedente o pedido determinando apenas a remoção e respectivo remanejamento das residências que estivessem localizadas na faixa marginal de proteção ambiental. Assim, o judiciário demostrou-se favorável à manutenção dos moradores na localidade, salvo aqueles que estivessem ocupando a faixa marginal. ${ }^{121}$

É importante destacar que antes do Município ingressar em juízo objetivando a demolição das casas, os moradores já pagavam imposto predial territorial urbano (IPTU) e taxa de energia elétrica. Após o registro da Associação de Moradores e Pescadores da Vila Autódromo, em 1987, vários moradores regularizaram os serviços de fornecimento de energia elétrica, telefone e coleta de lixo. ${ }^{122}$

Além da outorga do termo de concessão de uso em 1998 para os moradores que ocupavam a localidade à época, a Lei Complementar $\mathrm{n}^{\circ} 74$ de 14 de Janeiro de $2005^{123}$, durante o tramite da ação judicial acima referida, dentre outras determinações, declarou a área como Área de Especial Interesse Social (AEIS), excluindo a faixa marginal de proteção ambiental da Lagoa de Jacarepaguá e o Projeto de Alinhamento da Avenida Embaixador Aberlado Bueno (vide art. 9).

Em 2009, antes da sentença anteriormente aludida, veículos midiáticos noticiaram que a Municipalidade anunciou que, em função da realização dos megaeventos que seriam sediados pelo Brasil, mais de 3500 famílias de 6 comunidades das Zonas Oeste e Norte da cidade seriam removidas e dentre estas estaria a Vila Autódromo. ${ }^{124}$

Em 18 de dezembro de 2011, visando à garantia ao direito à moradia digna, com auxílio do Núcleo de Estudos e Projetos Habitacionais e Urbanos da Universidade Federal Fluminense (NEPHU/UFF) e Núcleo Experimental

\footnotetext{
${ }^{120}$ A tentativa de remoção dos moradores da Comunidade é antiga. Pode ser datada desde o início da década de 1990, durante o primeiro mandato do prefeito Cesar Maia, na época Eduardo Paes era Subprefeito da Zona Oeste. A gestão do referido Prefeito foi marcada pela urbanização e execução do Programa Favela-Bairro, entretanto também foi marcado por remoções de Comunidades na Zona Oeste.

${ }^{121}$ Ação Civil Pública, Restituição de área/Intervenção do Estado na Propriedade. $4^{\circ}$ Vara Fazendária, Comarca da Capital do Estado do Rio de Janeiro. Autos do processo $\mathrm{n}^{\circ}$ 1993.001.078414-7 (0081973-19.1993.8.19.0001). A Procuradoria do Município não recorreu da decisão, apenas a DPERJ discutindo a metragem da área de proteção. A ação ainda encontra-se em tramitação. Acesso 26 de agosto de 2015 .

${ }^{122}$ Informações extraídas da Contestação (fls.179/191)e dos documentos acostados a peça de defesa. Autos do processo ${ }^{\circ}$ 1993.001.078414-7 (0081973-19.1993.8.19.0001)

${ }^{123}$ Alguns moradores inclusive registraram seus títulos no Registro Geral de imóveis da região $-9^{\circ}$ ofício.

124 Entre as notícias veiculadas na mídia, destaca-se : Plano Olímpico para Rio-2016 prevê a remoção de favelas. Disponível em: $<$ http://www1.folha.uol.com.br/paywall/login.shtml?http://www1.folha.uol.com.br/fsp/esporte/f k0810200906.htm>.Acesso em 26 de agosto de 2015.
} 
de Planejamento Conflitual do Laboratório Estado, Trabalho, Território e Natureza do Instituto de Pesquisa e Planejamento Urbano e Regional da Universidade Federal do Rio de Janeiro (NEPLAC/ ETTERN/IPPUR/UFRJ) os moradores da Vila Autódromo deliberaram sobre um complexo Plano de Desenvolvimento Urbano, Econômico, Social e Cultural (Plano Popular da Vila Autódromo).

O Plano Popular da Vila Autódromo apresentou o diagnostico social da comunidade e alternativas técnicas visando à urbanização da mesma e sua integração à cidade do Rio de Janeiro. Através de levantamento físico, econômico e social da área é oferecido o conjunto das questões prioritárias e correspondentes soluções para áreas de habitação, saneamento, infraestrutura, meio ambiente, serviços públicos e cultural. ${ }^{125}$

Não obstante a elaboração do Plano Popular, o interesse da Administração Pública Municipal em remover a comunidade mostrou-se incontestável com a publicação no Diário Oficial do Município em 20 de julho de 2012 da Concessão Municipal de Licença expressa para demolição da comunidade Vila Autódromo, esta conferida à concessionária Rio Mais S.A, vencedora da licitação para construção do Parque Olímpico, composta pelas empresas Odebretch, Andrade Gutierrez e Carvalho Hosken. ${ }^{126}$ Em razão desse ato o Núcleo de Terras e Habitação da Defensoria do Estado do Rio de Janeiro ingressou em 2013 com a ação civil pública visando anulação da referida licença e garantia do direito à não remoção dos moradores. ${ }^{127}$

Entretanto, em que pese as discursões em juízo, em 2014 o Estado do Rio de Janeiro iniciou o reassentamento dos moradores, sendo estes removidos para o empreendimento habitacional denominado "Parque Carioca"128. O "Parque Carioca", localizado na Estrada dos Bandeirantes,

\footnotetext{
${ }^{125}$ Plano Popular da Vila Autódromo. Disponível em: $<$ https://comitepopulario.files.wordpress.com/2012/08/planopopularvilaautodromo.pdf $>$.Acesso em $12 / 10 / 2015$.

126 CONCESSÃO DE LICENÇA CONCESSIONÁRIA RIO MAIS S.A - CNPJ 15.404.443/000115, torna público que recebeu a Secretaria Municipal de Meio Ambiente - SMAC, através do processo $n^{\circ}$ 14/200.679/2012, a Licença Municipal de Instalação - LMI, com validade de 20 de junho de 2015, para a demolição das edificações que compõe o autódromo Nelson Piquet, a comunidade Vila Autódromo e o Clube de Ultraleves (CEU), localizado na Avenida Embaixador Abelardo Bueno, s/nº, Barra da Tijuca/RJ - Rio de Janeiro. 46898. Disponível em : < http://doweb.rio.rj.gov.br/ler_pdf.php?edi_id=2827\&page=101>.

127 Antes de ingressar com a referida ação civil pública (nº 0075959-18.2013.8.19.0001) o NUTH ajuizou ação cautelar ( $n^{\circ}$ 0013864-83.2012.8.19.0001)pleiteando que o Município esclarecesse o destino da comunidade. A ação cautelar foi julgada procedente e o Munícipio afirmou que parcela da comunidade estaria no trajeto da Transolimpica e Transcarioca. A ação cautelar foi ajuizada no contexto da licitação realizada pelo Município para contratação de empresa para construção do Parque Olímpico, visando, assim, esclarecer se a remoção da comunidade estaria incluída na da licitação.

${ }^{128}$ Moradores da Vila Autódromo se mudam para Parque Carioca. Disponível em: $<$ http://oglobo.globo.com/rio/bairros/moradores-da-vila-autodromo-se-mudam-para-parque-carioca$1-12058290>$.Acesso em 28/10/2014.
} 
pertencente ao programa do governo federal "Minha Casa, Minha Vida" e sob a tutela do município, foi empreendimento criado para atender os moradores removidos da Vila Autódromo.

Vários moradores foram reassentando, muitos dos quais, não estavam sequer nos traçados das supostas construções que atingiriam à comunidade. Muitos moradores aceitaram as propostas de reassentamento devido ao descaso do Poder Público com a localidade e as diversas pressões que lhe foram submetidos. Entre as pressões decantam-se as realizadas por funcionários da Prefeitura para que os mesmos optassem pelo reassentamento, as demolições que afetavam a infraestrutura do local e as reiteradas notícias veiculadas pela mídia que apresentavam falas da Prefeito afirmando que a comunidade seria removida.

Além disso, a Prefeitura tornou a proposta de reassentamento mais atrativa prometendo a construção playground, piscina e estacionamento no denominado "condomínio residencial" 129 e ainda prometeu entregar um cartão especial pelo qual o beneficiário teria cinco mil reais para compra de eletrodomésticos. ${ }^{130}$ É importante ressaltar que, por mais atrativo que pareça, os apartamentos de, em regra $40 \mathrm{~m} 2$, distanciam-se das casas dos moradores da Vila Autódromo, amplas e com quintal e, ainda, a mudança para o conjunto habitacional elevou o custo de vida para os moradores reassentados. ${ }^{131}$

Contudo, outros moradores não aceitaram a proposta de reassentamento, assim, o Município começou a oportunizar indenização, essa aceita por diversos moradores. Entre 2009 e 2013 cerca de 20.299 famílias foram removidas, seja indenizadas ou reassentadas. ${ }^{132}$ Entretanto, outros residentes da Vila Autódromo mantiveram-se resistentes não aceitando a proposta de reassentamento ou indenização.

Assim, visando remoção da Vila Autódromo, em março de 2015, o Chefe do Poder Executivo Municipal editou decretos no qual imóveis localizados na Vila Autódromo foram declarados de utilidade pública para fins de desapropriação. ${ }^{133}$ Tais decretos foram objetos de ações anulatórias

\footnotetext{
${ }^{129}$ Visita antes da decisão. $O$ Globo, 24 de outubro de 2013, jornal do bairro, página 8.

${ }^{130}$ Felicidade a $1 \mathrm{~km}$ de distância. $O$ Globo, jornal do bairro,03 de abril de 2014, página 6

131 Caminhos Divergentes: Moradores da Vila Autódromo Resistem, Seguem o Caminho, ou Aguardam. 15 de agosto de 2014. Disponível em< http://rioonwatch.org.br/?p=12090>, acesso em 16 de setembro de 2015.

132 Remoções na Vila Autódromo expõe o lado B das Olimpíadas do Rio. Disponível em < http://brasil.elpais.com/brasil/2015/06/20/politica/1434753946_363539.html>.Acesso em 23de junho de 2015.

133 Decreto n. 39851 de 18/03/2015, Decreto 39852 de 18/03/2015 e Decreto n. 39853 de $18 / 03 / 2015$.
} 
propostas pelos respectivos afetados e ação civil pública interposta pelo NUTH visando a nulidade do decreto expropriatório. ${ }^{134}$

\subsection{Vila Autódromo: Direito de permanência}

Conforme delineado no capítulo 1 existem várias normas nacionais e internacionais que tutelam o direito à permanência das comunidades carentes que não foram observadas in casu. Além dos extensos atos normativos, o Município deveria também respeitar direitos reais concedidos aos moradores da Vila Autódromo, que geraram aos mesmos legítimas expectativas quanto a permanência no espaço. Desse modo, o ato do Poder Público em remover os moradores ocorre violando as referidas normas e o princípio da confiança.

Consoante explicitado no capítulo primeiro o princípio da confiança não se circunscreve ao direito privado, mas é aplicado também na relação entre o Estado e o indivíduo fundamentando, assim, o direito a não remoção de favelas erguidas e não questionadas durante longo período de tempo.

O referido princípio tem aplicação no presente caso uma vez que o Estado e Município por um decurso temporal longínquo não questionaram legalmente, nem aturam com seu poder de polícia para a retirada da referida comunidade. A inércia prolongada das entidades federadas, a outorga de títulos de concessão de uso conferido pelo titular da área, a declaração da Área como de Especial Interesse Social e, ainda, a cobrança de tributos incidentes sobre os imóveis geraram legítimas expectativas aos moradores que não teriam suas casas demolidas, conferindo, segurança jurídica em relação ao direito de moradia.

Cabe, outrossim, ponderar que os moradores da Vila Autódromo instalaram suas residências na localidade, desenvolvendo identidade com a área abandonada pelo Poder Público, atribuindo-lhe função social. Desse modo, os moradores ao utilizarem área ociosa atribuindo-lhe função socioeconômica deveriam ser tutelados mesmo contra o Poder Público omisso nos termos do art. $5^{\circ}$, inciso XXXII CRFB/88- entendimento reiterado em manifestações pretorianas explicitadas no capítulo 1 .

\footnotetext{
${ }^{134}$ ACP n 0159686-98.2015.0001 visa anulação dos Decretos alegando que a)Parte dos imóveis objetos de desapropriação estão em Área definida como especial interesse social para fins de moradia(AEIS), não podendo a destinação ser alterada por decreto; b)Os imóveis foram objetos de concessão real de uso outorgados pelo Estado os quais o Munícipio compromete-se e respeitar ;c)Ausência de discriminação da utilidade pública determinada no decerto, e d) ausência de previsão orçamentária(Fls.6/7).Cabe, outrossim, ponderar que o Município ajuizou ações de desapropriação pleiteando a imissão na posse dos moradores cujas residências estão no decreto, muitos dos quais, fizeram acordo com a Prefeitura no curso da desapropriação.
} 
Vários moradores, em entrevista realizada por Clarissa Naback, descrevem como desenvolveram na comunidade sua moradia e identidade com espaço. A pesquisadora explicita que a partir da mobilização dos moradores foi iniciado um processo de urbanização com a plantação de árvores e implementação de tubulação, por exemplo. Afirma que "o urbano foi tecido pelos próprios moradores", mesmo sem o suporte do Estado. ${ }^{135}$ A autora ressalta, ainda, que a maioria dos moradores possuíam (os que permaneceram ainda possuem) regularidade em alguns serviços públicos, como coleta de lixo e energia elétrica, com medidor de luz. ${ }^{136}$

Com efeito, tendo em vista a existência de diversos instrumentos jurídicos (v.g. termos administrativos de Concessão de Uso concedido pelo Estado e a Lei Complementar $n^{\circ} 74 / 2005$ que declara a Área de Especial Interesse Social) aliada as normas nacionais e internacionais aplicáveis ao presente caso e os princípios da função social da posse e da confiança, irradiação do princípio da boa-fé, há necessária prevalência do direito a não remoção em detrimento de atos que elidem o direito à moradia. Desse modo, é notório que os moradores da Vila Autódromo possuem direito a permanecer na área.

A discursão que é colocada é se o Poder Público carioca poderia remover os moradores objetivando o interesse público, tendo em vista que esta é a justificativa apresentada para remoção da Vila Autódromo.

Trata-se de um tema complexo uma vez que a Constituição do Estado do Rio de Janeiro bem como a Lei Orgânica do Munícipio, conforme explicitado no capítulo 1, consagram expressamente o direito a não remoção, sendo excepcionalmente admitida quando as condições físicas da área ocupada imponham risco de vida aos seus habitantes, o que não se verifica no presente caso.

Entretanto, por outro lado, tal como explicitado no capítulo primeiro, o constituinte previu a possibilidade de transferência da titularidade da área ou imóvel ao Poder Público, fundado na necessidade pública, utilidade pública ou interesse social, mediante pagamento de justa e prévia indenização.

Assim, ainda que fosse possível a remoção de comunidades fundada no "interesse público", é preciso que o ato respeite o conjunto de princípios e regras previsto em todo ordenamento jurídico, entre outros deveres, a

\footnotetext{
${ }^{135}$ NABACK, Clarissa Pires de Alemida . Remoções biopoliticas: o habitar e a resistência da Vila Autódromo. p 99.

${ }^{136}$ NABACK, Clarissa Pires de Alemida . Remoções biopoliticas: o habitar e a resistência da Vila Autódromo. p 102.
} 
fundamentação expressa do ato, participação da comunidade interessada para análise do ato e definição de soluções. Desse modo, inclusive o interesse público, inserido no contexto do sistema democrático e dos direitos fundamentais, é reformulado, sendo obtido a partir de ponderação razoável e racional dos interesses envolvidos.

\subsection{Justificativas apresentadas pela Prefeitura para remoção da Vila Autódromo}

Visando justificar a necessidade de remoção dos moradores da Vila Autódromo foram apresentados diferentes argumentos desde 1993 até o presente momento. ${ }^{137}$ Além da justificativa ambiental exposta na década de 90, em 8 de outubro de 2009, após o anúncio da escolha do Rio de Janeiro para sediar os Jogos Olímpicos em 2016, foi noticiado que visando atender as exigências do Comitê Olímpico Internacional (COI) "o plano para viabilizar a realização dos Jogos no Rio de Janeiro de 2016 prevê a remoção de mais de 3.500 famílias de seis favelas das zonas oeste e norte da cidade"138

A mesma reportagem afirma que em 2006, antes da realização do Pan Americano no Rio de janeiro, durante a terceira gestão do prefeito Cesar Maia, os moradores tiveram as casas marcadas pela Secretária Municipal de Habitação com promessa de reassentamento. Cerca de dois meses após a veiculação da referida matéria foi noticiado que o prefeito Eduardo Paes anunciou seu Plano Estratégico de Governo (2009-2012) cujo um dos objetivos, contendo 46 metas, seria o de "reduzir em 3,5\% (1,6 milhão de metros quadrados, o equivalente a duas Rocinhas) as áreas ocupadas por favelas no Rio." 139

Ainda em 2009 o prefeito Eduardo Paes, declarou publicamente que Vila Autódromo seria removida para fins dos Jogos Olímpicos. No ano

\footnotetext{
137 Justificativa apresentada pela Municipalidade: Comunidade causa dano ambiental, estético, turístico e paisagístico. Autos do processo n ${ }^{\circ}$ 1993.001.078414-7 (0081973-19.1993.8.19.0001). É imperioso estacar que notícia veiculada no jornal $O$ Globo, em 1987, sinaliza que naquele ano ocorreu tentativa de retirar famílias da comunidade. Fonte: Mudança de 80 famílias provoca protesto em moradores de Curicica. O Globo, 01 de março de 1987, Caderno,p. 16.

138 Plano Olímpico prevê a remoção de favelas.Folha de São Paulo, 08 de outubro de 2009. Disponível

$<$ http://www1.folha.uol.com.br/paywall/login.shtml?http://www1.folha.uol.com.br/fsp/esporte/fk08 10200906.htm>. Acesso em 09 de outubro de 2015.

${ }^{139}$ Plano estratégico: Paes quer reduzir e 3,5\% total da área de favelas até 2012. Disponível em $:<$ http://extra.globo.com/noticias/rio/plano-estrategico-paes-quer-reduzir-em-35-total-da-area-defavelas-ate-2012-207796.html\#ixzz3kWxd9aCS>. Acesso em 09 de outubro de 2015.
} 
seguinte foi apregoado que a Vila Autódromo estaria entre as comunidades que seriam integralmente removidas. ${ }^{140}$

Após manifestação dos moradores em frente à Prefeitura, em março de 2010, o prefeito Eduardo Paes recebeu moradores e fundamentou a necessidade de remoção como "exigência do COI". No mesmo mês representante da Prefeitura, em reunião com moradores, Defensores Públicos e arquitetos, afirmaram que a comunidade estava "inserida no perímetro de segurança, onde seria criado área livre". ${ }^{141}$

O Parecer Técnico, requerido pelo Núcleo de Terras e Habitação da DPRJ, apresentado em 13 de maio de 2010 sistematizou os principais argumentos apresentados pela Prefeitura para remoção da Vila Autódromo (anexo 1). ${ }^{142}$ Segundo o referido parecer os principais fundamentos foram:

a) necessidade de execução de obras de ampliação das avenidas Embaixador Abelardo Bueno e Salvador Allende; b)necessidade de construção do Centro de Mídia-hospedagem dos jornalistas ; c) existência de dificuldades técnicas para execução das obras de urbanização na comunidade; d)Localização de parte da Comunidade no perímetro de segurança do Parque Olímpico e e) localização de parte da Comunidade na Faixa de Proteção Marginal. $^{143}$

O parecer analisou cada argumento e concluiu que a execução das obras mencionadas nas justificativas acima nos itens (a) e (b) e também os motivos apresentados em (d) e (e) não produziria qualquer interferência na área ocupada pela a comunidade. Em relação a justificativa (c) o parecer conclui que o volume de intervenções previstas para área que abrigaria o Parque Olímpico, a Vila de Mídia e Vila Olímpica que poderia gerar discussões acerca da viabilidade técnica e não a urbanização da comunidade. Desse modo, o parecer concluiu, em 2010, que não existiam fundamentos técnicos, relacionado à realização dos Jogos para remoção da comunidade.

Sr. João, morador da Comunidade desde 2002, afirma, em entrevista realizada por Clarissa Naback, que a Prefeitura apresentava aos moradores

\footnotetext{
140 Prefeitura removerá 119 favelas até o fim de 2012. Disponível em $<$ http://oglobo.globo.com/rio/prefeitura-removera-119-favelas-ate-fim-de-2012-3072053>.Acesso em 10/09/2015.

${ }^{141}$ NABACK, Clarissa. Remoções biopoliticas : o habitar e a resistência da Vila Autódromo. p.116

${ }^{142}$ Parecer Técnico - Vila Autódromo : O Direito à moradia , o Direito à Cidade e a Rio 2016 13/05/2015.Elaborado por Canagé Vilhena (Arquiteto e Urbanista);Jorge Luís Borges ( Geógrafo), Marcos de Faria Azevedo (Arquiteto e urbanista). Maurício Campos dos Santos( Engenheiro Civil e Mecânico) Valéria Barbalho(Engenheiro Civil).O referido parecer sistematiza os argumentos a partir de notícias veiculadas na mídia e a partir das reuniões realizadas desde fevereiro de 2010 até março do referido ano com o prefeito Eduardo Paes, representantes da comunidade , da Defensoria Pública, com o Secretário de Habitação, Jorge Bittar entre outros

143 Parecer Técnico - Vila Autódromo : O Direito à moradia, o Direito à Cidade e a Rio 2016.Página 6
} 
diferentes justificativas sobre a destinação da área e depois eles "descobriam" que não era veraz a informação apresentada. Afirmou ainda que a Prefeitura realizou apenas duas reuniões com representantes da Comunidade para esclarecer sobre os projetos destinados à área.

Naback relata que o Município apresentou diferentes justificativas para remoção aos moradores e à Defensoria Pública, mas que a maioria esteve relacionada aos Jogos Olímpicos de 2016. A pesquisadora ratifica a conclusão do parecer afirmando que a remoção da Vila Autódromo não está “diretamente atrelada aos Jogos e que sua área não está afetada pelo perímetro de construção do Parque Olímpico". ${ }^{144}$

A autora pontua que os argumentos apresentados mostraram-se insustentáveis, sobretudo os relacionados a "exigências do COI", ressaltando que o Plano Geral Urbanístico do Parque Olímpico Rio 2016 manteve grande parte da Vila Autódromo intacta e localizou o Centro de Mídia próximo ao terreno ocupado pelo Autódromo de Jacarepaguá. ${ }^{145}$

Assim, diante das constantes ameaças de remoções noticiadas pelos veículos midiáticos e pelos representantes do Poder Público, a Defensoria Pública do Estado do Rio de Janeiro e a Associação de Moradores e Pescadores da Vila Autódromo ingressaram em juízo, em 2012, com ação cautelar inominada pleiteando que o Município do Rio de Janeiro prestasse informações quanto ao destino dos moradores da Vila Autódromo. ${ }^{146}$

No curso do supramencionado processo o Município afirmou que a área da Vila Autódromo estaria fora da execução do Parque Olímpico, mas seria necessária para implementação do projeto viário e urbanístico da região (Transolímpica e Transcarioca), justificando que se trata de interesse público. ${ }^{147}$

Não obstante a Prefeitura afirmar em juízo que a remoção dos moradores não guardava relação com os Jogos Olímpicos, o prefeito Eduardo Paes assegurou que a Vila Autódromo iria abrigar o Centro de Mídia, estacionamentos e estruturas provisórias para realização dos jogos. ${ }^{148}$ Ao Tribunal de Contas do Município a Prefeitura informou que na localidade onde se encontra a Vila Autódromo seria construído

\footnotetext{
144 NABACK, Clarissa. Remoções biopoliticas: o habitar e a resistência da Vila Autódromo. pg. 115

145 Ibid. .pg. 117

$1465^{\mathrm{a}}$ Vara da Fazenda Pública Autos do processo: $\mathrm{n}^{\circ}$ 0013864-83.2012.8.19.0001

$1475^{\mathrm{a}}$ Vara da Fazenda Pública Autos do processo: $\mathrm{n}^{\circ}$ 0013864-83.2012.8.19.0001. fls 61-71.

148 Prefeito Eduardo Paes fala sobre remoção de famílias da Vila Autódromo. Publicado em 21 de novembro de 2012. Disponível em < http://www.radiobetel98fm.com.br/novo/2012/11/21/prefeitoeduardo-paes-fala-sobre-remocao-de-familias-da-vila-autodromo/>.Acesso e 5 de fevereiro de 2013.
} 
estacionamento de veículos e área de proteção ambiental (Processo 040/8623/2012). Ainda em 2012 após a justificativa apresentada nos autos da ação cautelar, o Município concedeu licença expressa para demolição à Concessionária Rio Mais, vencedora da construção do Parque Olímpico.

Como poderia o Município afirmar em juízo que a remoção da Vila Autódromo não guarda nenhuma relação com o Parque Olímpico e conceder licença de demolição para concessionária responsável pela construção do Parque Olímpico?

A concessão municipal de licença revelou as posturas contraditórias adotadas pelo Poder Público em relação às informações apresentadas anteriormente em juízo.

A partir de 2013, o prefeito Eduardo Paes atesta que Vila Autódromo não será removida e que a remoção atingirá apenas os moradores cujas construções estivessem localizadas na Faixa marginal e na entrada da comunidade. Apresentou novas justificativas para remoção desses moradores, afirmando que estaria relacionada à duplicação da av. Abelardo Bueno e Salvador Allende, e, construção de vias de acessos e passarelas para o Parque Olímpico. ${ }^{149}$

Observam-se, nesse ato, que o chefe do poder executivo municipal associa a necessidade de remoção às obras olímpicas. Entretanto ainda em 2013, o Munícipio novamente afirma, agora em sede de Ação Civil Pública, que não guarda relação com a construção do Parque Olímpico, mas a remoção se dá por "motivo de restauração da ordem e recuperação do meio ambiente". ${ }^{150}$

A justificativa ambiental apresentada pela Municipalidade é questionável. Outras construções erguidas na Barra da Tijuca causam prejuízos ao meio ambiente, mas nunca foram questionadas. Além disso, a sentença proferida nos autos da ação civil pública de número 008197319.1993.8.19.0001 determinou a retirada apenas dos moradores que estivessem situados na faixa marginal.

O parecer do Ministério Público apresentado nos autos da supramencionada ação (apelação cível no 0081973-19.1993.8.0001) pontua a ausência de isonomia tendo em vista que "existem inúmeras construções luxuosas localizadas em faixa marginal de proteção e o poder público objetiva apenas a retirada da comunidade carente". Nesse sentido, o Ministério Público afirma que muitas construções próximas, como luxuosos

\footnotetext{
${ }^{149}$ Naback, Clarissa. Remoções biopoliticas: o habitar e a resistência da Vila Autódromo.p. 118 ${ }^{150}$ Ação civil pública no 0075959-18.2013.8.19.0001, Contestação do Município (Fls.139/149)
} 
condomínios, nunca foram questionadas do ponto de vista ambiental em juízo.

Diante de todo exposto, observa-se, assim, postura contraditória da Municipalidade ao apresentar diferentes justificativas para remoção da Vila Autódromo. Conforme explicado o Prefeito afirmou que a remoção estaria vinculada a execução de obras para realização dos megaeventos, entretanto em conforme já mencionado, em juízo, o Município afirma que a construção das vias expressas é o fundamento para remoção e esta não esta relacionada à realização dos Jogos Olímpicos, mas sim o "motivo de restauração da ordem e recuperação do meio ambiente".

\subsection{Análise da fundamentação da remoção sob ótica da legalidade (juridicidade administrativa), publicidade e moralidade pública.}

O Município desconsiderando as normas que tutelam o direito à permanência dos moradores, os títulos de posse que lhe foram outorgados e a par do interesse social já reconhecido em Lei Complementar destinou a área pra atender finalidades escusas.

Diante de numerosas justificativas apresentadas pelo Poder Público torna-se inevitável a seguinte indagação: qual o real motivo pelo qual o Poder Público pretende remover a Vila Autódromo? O que objetiva o Poder Público fazer na localidade?

Não obstante os questionamentos que se apresentam é fato a se constatar que o ordenamento jurídico veda atuação administrativa desprovida de legalidade, moralidade, impessoalidade, publicidade, eficiência e, ainda, dissociada do "interesse público".

Ao que parece, com base nas informações prestadas pelos moradores ${ }^{151}$ e por estudiosos o que pretende realmente o Poder Público é a remoção de toda comunidade per ser e que os verdadeiros motivos para tal ato administrativo não foram revelados.

A referida postura da municipalidade - apresentação de diferentes justificativas para pratica do mesmo ato administrativo - representa violação aos princípios que regem a atuação da Administração Pública, em especial, moralidade pública, publicidade, transparência e juridicidade.

\footnotetext{
${ }^{151}$ Entrevistas em anexo na dissertação de mestrado produzida por Clarissa Naback e reuniões com os moradores no NUTH .
} 
$\mathrm{O}$ art. 37 da Constituição da República consagra princípios que devem reger a atuação da administração pública. Entre os princípios elencados no referido dispositivo normativo encontra-se a publicidade. Tal como delineado no capítulo 1 o princípio constitucional da publicidade expressa os anseios do regime democrático o qual a administração pública deve conduzir seus atos pela transparência.

Tal norma indica que os atos administrativos devem ser divulgados da forma mais ampla possível para que os administrados possam ter íntegro conhecimento do seu teor. Conforme explicado Celso Antônio Bandeira de Mello, define o princípio como sendo “(...) o dever administrativo de manter plena transparência em seus comportamentos". ${ }^{152}$

As políticas públicas, quer sejam planos, programas ou projetos, precisam informadas a sociedade. O princípio da publicidade é ínsito ao princípio republicano sendo dimensão do princípio democrático. Em regime democrático é necessário que todos tenham conhecimento dos atos estatais.

Desse modo, o ente público tem o dever de prestar informações transparentes quanto às intensões de atuação. Entretanto ao analisar o caso da Vila Autódromo constata-se a não transparência do Município ao prestar informações diferentes e contraditórias quanto ao destino da referida Comunidade e os motivos que fundamentam sua remoção.

Além da publicidade, o agir da Administração Pública deve ser guiado também pela moralidade administrativa. Conforme já explicitado este impõe que administrador paute sua conduta pela lealdade e boa-fé. Desse modo, além de violação ao princípio da publicidade o agir da Administração representa ofensa ao princípio da moralidade administrativa.

A inobservância do referido princípio é verificada nas ações incoerentes da municipalidade. Esta não agiu com honestidade e lealdade aos moradores ao apresentar diferentes justificativas para remoção, adotar posturas contraditórias e "ao remover os moradores que aceitam suas pressões enquanto promete aos que ficam que a comunidade será urbanizada". ${ }^{153}$

Segundo delineado na primeira parte da monografia exige-se da Administração dever de honestidade em relação aos recursos que o Estado tutela, múnus de zelo pela res pública e boa-fé e lealdade para com os administrados.

\footnotetext{
${ }^{152}$ MELLO, Celso Antônio Bandeira de. Curso de Direito Administrativo.pg. 114

153 Eduardo Paes Mente! Moradores da Vila Autódromo lutam para não sair. Disponível em: < https://www.youtube.com/watch?v=5w3YbHqmL-0>.Acesso em 18/10/2015.
} 
A conduta do Poder Público, in casu, evidencia desonestidade para com moradores e com toda sociedade. As diferentes justificativas para prática do mesmo ato administrativo relevam procedimentos desleais que prejudicam as legítimas expectativas dos administrados.

Celso Antônio Bandeira de Mello, atenta para o fato de que "as orientações firmadas pela Administração em dada matéria não podem, sem prévia e pública notícia, ser modificada em casos concretos a fim de sancionar ou agravar a situação dos administrados (...)". ${ }^{154}$

Observa-se no caso em análise que a Administração reiteradas vezes apresentou motivos oscilantes e mudou suas posturas sem fundamentação idônea e publicidade prévia, ora afirmando que a Vila Autódromo seria removida por determinado motivo, ora por outro, e ora garantindo que parcelas dos moradores iriam permanecer na área, paralelamente procedendo à remoção infundada.

Além desses atos, a ofensa ao referido princípio também pode ser verificada quando o chefe do Poder Executivo Municipal afirma que é possível o reassentamento do morador removido dentro da comunidade em área que não está afetada por nenhum projeto. Entretanto atua contraditoriamente não permitindo reassentamento do morador em outra área da Vila Autódromo apenas apresentando proposta de indenização ou reassentamento no Parque Carioca. ${ }^{155}$

Nesse sentido, leia o trecho da entrevista realiza pela BBC Brasil com o Prefeito:

BBC Brasil - Então podemos cravar isso, que uma parte da Vila Autódromo vai ficar? Qual parte vai ficar?

Paes - Sim, e eu digo isso para eles todo dia, desde o início. Eles têm vários vídeos meus gravados. A gente já apresentou esse mapa. O que sai são os acessos ao Parque Olímpico e a beira da Lagoa, onde tinha um monte de gente rica e é área de proteção ambiental. Todo o resto fica. Só sai quem quer. ${ }^{156}$

O prefeito Eduardo Paes assevera que muitos tem interesse em sair da Vila Autódromo, evidenciando que se trata de remoção voluntária. Entretanto, funcionários da Prefeitura pressionaram moradores para que

\footnotetext{
${ }^{154}$ MELLO, Celso Antônio Bandeira de. Curso de Direito Administrativo. pg. 120

${ }^{155}$ Nota pública: Vila Autódromo conquista sua permanência. Disponível em<

https://comitepopulario.wordpress.com/2013/08/09/nota-publica-vila-autodromo-conquista-suapermanencia/>.Acesso em 18/10/201.

${ }^{156}$ Paes ataca 'dono da Barra': 'Não entendeu significado dos Jogos para o Rio'. Disponível em:< http://www.bbc.com/portuguese/noticias/2015/08/150815_entrevista_eduardo_paes_hb_jp $>$.Acesso em 24/10/2015.
} 
optassem pelo reassentamento afirmando que as casas situadas na comunidade seriam todas demolidas e ninguém permaneceria na localidade. Essa pressão associada ao descaso da Municipalidade na área insalubridade em virtude de entulhos decorrentes de demolições e os impactos das obras olímpicas na comunidade ${ }^{157}$ - fizeram com que vários moradores optassem pelo reassentamento. ${ }^{158}$

O discurso proferido pelo Poder Público de "livre escolha" dos moradores, "remoção consentida" e o famoso "saí da comunidade quem quer" 159 esconde a pressão realizada por funcionários da Prefeitura para que as famílias optem pela proposta oferecida pela municipalidade. Assim, moradores pressionados e sem efetiva liberdade de escolha, diante da coação psicológica realizada pelo poder público, aceitam as propostas oferecidas pela municipalidade, pois as enxergam como solução seus problemas habitacionais.

Segundo Naback são várias as "estratégias subterrâneas" que foram utilizadas pela Prefeitura, inclusive orientando moradores convencer seus vizinhos a persuadirem outras famílias a aceitarem os apartamentos no Parque Carioca. A pesquisadora afirma que funcionários da Prefeitura frequentavam rotineiramente a comunidade objetivando convencer os moradores para que aderirem às propostas apresentadas pela municipalidade ${ }^{160}$.

O Dossiê da Articulação Nacional dos Comitês Populares da Copa também pontua as estratégias utilizadas pela Prefeitura. Entre elas ressalta a "terceirização da violência verbal contra os moradores, as ameaças à integridade física e aos direitos fundamentais das famílias, o corte dos serviços públicos ou a demolição e o abandono dos escombros de uma em cada três casas subsequentes, para que toda e qualquer família tenha como vizinho o cenário de terror."161

\footnotetext{
157 Vila Autódromo sobre com os impactos das Obras Olímpicas. Disponível em: < https://www.youtube.com/watch?v=WRG_cKMhiM\&feature=share $>$. Acesso em 09/11/2015.

158 Os Conflitos fundiários no Brasil: estratégias de luta contra os despejos e empoderamento a partir da teoria crítica de direitos humanos. Organizadores: Cristiano Muller,Karla Fabricia Moroso dos Santos Azevedo. PONTES. Maria Lúcia de. Comunidade Indiana -Programa Minha Casa Minha Vida: Incentivo à politica habitacional ou mecanismo de estímulo à remoção. pg 77

159 Discurso do Prefeito. Disponível em<https://www.youtube.com/watch?v=RZG1S9hxHuE $>$. Acesso em 10/10/2015.

${ }^{160}$ NABACK, Clarissa. Remoções biopoliticas: o habitar e a resistência da Vila Autódromo. p 127 e Vila Autódromo Unida em um ato após semana de pressão. Disponível em: $<$ http://rioonwatch.org.br/?p=7034. $>$ Acesso em 29/09/2015.

161 DOSSIE DA ARTICULAÇÃO NACIONAL DOS COMITÊS POPULARES DA COPA. Megaeventos e Violação de Direitos Humanos no Brasil. Pg 19.Disponível em:< http://www.apublica.org/wp-content/uploads/2012/01/DossieViolacoesCopa.pdf>, Acesso $28 \mathrm{de}$ setembro de 2015.
} 
Essas técnicas remocionistas viciam a vontade do morador. Atos de convencimentos através de ameaças psicológicas e discursos que estimulam a vontade dos moradores de sair da comunidade trata-se de "aceitação" viciada. Clarissa Naback denomina essas técnicas de "ações marginais do poder". ${ }^{162}$

Os moradores cedem às pressões e aceitam as propostas, mas o desejo real da Vila Autódromo é permanecer. Essa vontade é verificada através da resistência de muitos e ainda expressamente nas redes sociais e em juízo, como na audiência especial no âmbito da ACP que discute as questões ambientais atinentes a Vila Autódromo (Autos do processo 008197319.1993.8.0001).

Desse modo, moradores das áreas as quais o prefeito afirmou que iriam permanecer estão negociando com a Prefeitura ou sendo removidos. O parecer do Ministério Público apresentado nos autos da ACP (Apelação cível $\mathrm{n}^{\mathrm{o}}$ 0081973-19.1993.8.0001) afirma que a Prefeitura demoliu imóveis sem oferecer proposta de acordo. O referido parecer relata que essas praticas são reiteradas e que a municipalidade tem negociado diretamente com os moradores cujas casas encontram-se em áreas não destinadas a nenhum projeto público.

Em síntese, verificam-se, assim, as seguintes posturas da municipalidade carioca: a) apresentação de diferentes justificativas para o mesmo ato administrativo; b) justificativas que segundo especialistas não afetariam toda parcela da Vila Autódromo; c) remoção de moradores sem que seja apresentado fundamento prévio para tal ato.

Destarte, as referidas posturas revelam transgressão da juridicidade, expressão da legalidade administrativa. Nesse sentido, a atuação da Administração Pública é vinculada não apenas a lei em sentido estrito, mas a todo sistema jurídico vigente que abrange os princípios que o embasam, entre eles, os princípios da impessoalidade, moralidade, publicidade e eficiência (art. 37 caput CRFB/88).

Com emergência da ideia de juridicidade administrativa, os atos administrativos, inclusive discricionários, encontram-se vinculados diretamente aos preceitos constitucionais. Assim, o motivo e a fundamentação dos atos e das politicas públicas também se encontram vinculados ao conteúdo dos princípios.

$\mathrm{O}$ ato de remoção dos moradores da Vila Autódromo está fundamentado em motivos escusos, contraditórios, e não apesentados.

\footnotetext{
${ }^{162}$ NABACK, Clarissa. Remoções biopoliticas: o habitar e a resistência da Vila Autódromo. p. 90 .
} 
Assim, além de violar a publicidade, transparência e a moralidade pública, o ato viola a juridicidade, uma vez revela que se se trata de ato administrativo desprovido de motivo preexistente, violando, assim, as exigências do ordenamento jurídico. Inserido no sistema de direitos fundamentais e no contexto democrático exige-se que o ato administrativo seja motivado e que o motivo seja prévio e idôneo.

\subsection{Motivos para remoção da Vila Autódromo.}

As premissas teórico-normativas expostas no capítulo primeiro salientam a necessidade de que todo ato administrativo deve apresentar motivo prévio e idôneo. Este é definido como a situação fática ou de direito que autoriza a administração pública agir. Nesse sentido, a validade do ato administrativo depende da existência de motivo anterior e idôneo, assim, se o motivo do ato for inexistente ou não for idôneo, o ato será eivado de nulidade.

A Municipalidade apresentou diferentes motivos para remoção de parcela da Vila Autódromo. Em relação à outra parte ${ }^{163}$ da comunidade sequer foram apresentados motivos que deram causa as remoções. Assim, não foi esclarecido previamente o motivo que autorizaria a Administração agir.

Apresentação de vários motivos para pratica do mesmo ato não é suficiente, pois se exige como já explicitado, lealdade e boa-fé com os administrados e recursos que o Estado tutela. É necessário que a Administração demostre que motivo previamente existia, que era idôneo e que foi determinante para pratica do ato.

No contexto do sistema democrático e dos direitos fundamentais, seria imperioso que o Poder Público apresentasse expressamente o projeto específico destinado a localidade e as situações fáticas que ensejaram a necessidade de remoção.

Conforme apresentados na primeira parte da monografia, grande parte da doutrina afirma que existe dever de motivação, ou seja, a regra é a de que os atos administrativos sejam motivados expressamente, sejam atos discricionários ou vinculados.

Se o Poder Público determina a remoção de favela é preciso que este fundamente expressamente o motivo que embasou tal ato. Se não houver

\footnotetext{
${ }^{163}$ Esta parte é chamada pelos moradores de "miolo" da Vila Autódromo.
} 
motivos para a prática do ato ou se este não for idôneo ou juridicamente inadequado, o ato será eivado de nulidade e atuação da Administração Pública violará a juridicidade, uma vez que o ordenamento jurídico exige que o ato administrativo seja provido de motivo prévio e idôneo. Desse modo, conclui-se que a não apresentação de motivos para remoção da Vila Autódromo e apresentação de motivos contraditórios representa violação da juridicidade.

Nesse sentido, conforme julgado apresentado no capítulo 1, o STJ já decidiu que existe vício de legalidade quando "verificada a falta de congruência entre as razoes explicitadas no ato e o resultado nele contido" (MS 15.290/DF, Rel. Min. Castro Meira, Primeira Seção, julgado em 26.10.2011, DJe 14.11.2011). Assim, o ato da Administração de apresentar motivos inverídicos para remoção da Vila Autódromo representa ofensa a legalidade, mais especificamente, afronta a juridicidade administrativa, uma vez que ofende não apenas a lei estrito senso, mas também fere a publicidade, transparência e moralidade administrativa, violando a boa-fé que se espera do administrador.

Entretanto é imperioso destacar, ainda que o Poder Público apresentasse previamente a causa de agir idônea e devidamente comprovada para remoção da favela haveria necessidade da ponderação dos princípios fundamentais em tela, essencial quando há o conflito de dois princípios de ordem constitucional.

O Poder Público afirma que possui interesse na área para implementar projeto de "interesse público que se sobrepõe ao direito de propriedade ou posse". ${ }^{164}$ Entretanto analisando as premissas teóricas-normativas apresentadas no primeiro capítulo, verifica-se que no sistema democrático e de direitos fundamentais o interesse que deve prevalecer é obtido a partir da ponderação razoável e racional dos direitos envolvidos. Além disso, o interesse público não se perfaz dissociado do ordenamento jurídico.

\subsection{Remoção da Vila Autódromo sob justificativa de Interesse Público}

O capítulo 1 destacou o princípio da supremacia do interesse público e apresentou a crítica de parte da doutrina em relação a tal princípio. Gustavo Binenboijm explicitou nova concepção da "supremacia do interesse

$1645^{\mathrm{a}}$ Vara da Fazenda Pública Autos do processo : n 0013864-83.2012.8.19.0001 fls 65/66.É importante mencionar que o Municipalidade, conforme mencionado reiteradas vezes, justifica a remoção com base em diferentes motivos, apresentando o interesse público "genericamente". 
público" propondo sua abolição. O referido autor sinalizou que separação inconfundível entre interesse público e interesses individuais e a supremacia absoluta dos interesses metaindividuais é incompatível com a constitucionalização do direito administrativo e com consagração dos direitos fundamentais e democrático.

Binenboijm pontuou que o interesse público não é a somatória dos direitos individuais, nem tampouco se confunde com interesse coletivo ou metaindividual, mas é aquele interesse que emerge da vivência em comunidade, sendo interesse de todo conjunto social, imbricação entre interesses individuais e interesses da coletividade.

Viu-se que outros autores criticaram a doutrina que defende abolição do princípio considerado a base do direito administrativo, tal como Maria Zanella de Pietro e Cláudio Penedo Madureira. Afirmam, assim, que a supremacia do interesse público não deve ser utilizada de maneira autoritária, mas deve ser utilizada em consonância com todo ordenamento jurídico. Desse modo, o princípio só seria observado se todos os demais comandos constitucionais e infraconstitucionais e legais forem observados.

Destarte, considerando a doutrina clássica e os argumentos defendidos pela contemporânea, no capítulo 1, defendeu-se a ideia que: é possível sustentar a prevalência do interesse público, entretanto, este deverá ser obtido a partir da ponderação razoável dos interesses envolvidos e aplicação das premissas previstas no ordenamento jurídico. Desse modo, o "interesse público" não seria antagônico ao "interesse privado", podendo inclusive significar a tutela do interesse particular no caso concreto.

Com efeito, para se verificar o interesse que deve prevalecer, o administrador deve utilizar os postulados da razoabilidade e da proporcionalidade $^{165}$, exercendo assim um juízo de ponderação entre os direitos individuais e coletivos específicos em tela. Tal juízo de deve permitir aplicação máxima dos interesses envolvidos e revelar o "interesse público". 166

O Município justifica que a remoção da Vila Autódromo trata-se de interesse público. Não obstante as discursões delineadas anteriormente, ainda que os motivos apresentados fossem prévios e idôneos seria necessário

\footnotetext{
165 Trata da tríplice estrutura do postulado da proporcionalidade. Nessa seara a restrição de um interesse é apenas justificada quando não houver outra solução menos onerosa, se garantir o outro interesse em conflito e se o benéfico atingido compensar a restrição ao interesse contraposto. Nesse sentido recomenda-se a leitura : SARMENTO, Daniel.A Ponderação de Interesses na Constituição Federal, $1^{\circ}$ ed, $3^{\circ}$ tir. Rio de Janeiro Lumen Juris, 2003.

166 Apenas é possível falar ponderação entre interesses públicos e particulares quando estes são legítimos. Favoritismos pessoais em jogo não podem ser considerados, visto que estes envolvem per ser violação aos princípios da impessoalidade e moralidade administrativa.
} 
a ponderação, devendo prevalecer aquele interesse que mais se aproximasse da tutela dignidade da pessoa humana e dos anseios do constituinte originário.

A maioria das justificativas esteve relacionada aos Jogos Olímpicos. Assim, verifica-se o direito de permanência dos moradores e o direito de realização dos Jogos Olímpicos em conflito. Conforme mencionado, o direito de não remoção está assentado sobre o direito à moradia, peremptório para o exercício de outros direitos.

Os Jogos Olímpicos, em última análise, poderiam estar associados ao direito ao entretenimento ou à arrecadação tributária. Além disto, os eventos olímpicos exigem obras de grande porte que, muitas vezes, ficam sem destinação pública após a realização de tais eventos. Ademais, a remoção da Vila Autódromo representou grande impacto nos cofres públicos (anexo $2)^{167}$

Assim, ponderando os interesses envolvidos no presente $\mathrm{e}$ as exigências do ordenamento o interesse público deveria ser tutela do direito à moradia da população de baixa renda. Segundo Binenbojm "muitas vezes, a promoção do interesse público, entendido como conjunto de metas gerais da coletividade juridicamente consagrada-consiste justamente na preservação de um interesse individual, na maior medida possível." ${ }^{168}$ Dessa forma, seria necessário o Poder Público elaborar projeto menos oneroso para os cofres e que não afetasse a Comunidade.

$\mathrm{O}$ mesmo exercício deveria ser feito em relação à justificativa "rodoviária", buscando, assim, um traçado que representasse a menor onerosidade dos cofres públicos e restrição dos direitos dos moradores. ${ }^{169}$ As normas que fundamentam o direito de permanência explicitam que a remoção deve ser ato excepcional a ser realizado quando não há alternativa adequada e viável.

Nesse sentido, foram citados no capítulo 1 extensos instrumentos normativos que consagram que a permanência de favelas é interesse público. Destacaram-se os instrumentos do Estatuto da Cidade que visam à garantia de tal direito através dos instrumentos que visam a legalização da moradia em assentamento ditos irregulares, destacou-se a Lei Federal n. 11.124, de

\footnotetext{
167 Além dos gastos com a construção do Parque Olímpico (cerca de 105 milhões. Fonte $<$ http://www.bbc.com/portuguese/noticias/2015/03/150305_rio2016_vila_autodromo_rm_jp $>$ ): , a Prefeitura desembolsou milhões com as indenizações dos moradores.

${ }^{168}$ BINENBOJM, Gustavo. Uma teoria do direito administrativo: direitos fundamentais, democracia e constitucionalização. 2. ed. Rio de Janeiro: Renovar,2014,pg 324

169 Por exemplo desenvolvendo projeto que que não afetasse a comunidade, ou, que afetando parte dela, realizasse projeto de urbanização da parcela não removida.
} 
16/06/2005, que determina a "utilização prioritária de terrenos de propriedade do Poder Público para a implantação de projetos habitacionais de interesse social". No âmbito da Legislação do Rio de Janeiro citou-se a Leia orgânica do Município que estabelece a urbanização dos assentamentos de baixa renda assegura as funções sociais da cidade e os anseios do constituinte (art. 430 da Lei Orgânica do Município).

Desse modo, se, eventualmente, fosse imprescindível a retirada de alguns moradores, as soluções deveriam ser discutidas com os afetados nos termos do art. art. 429, VI, "c" da Lei Orgânica do Município que exige a "participação da comunidade interessada e das entidades representativas na análise e definição das soluções"( art. 429, VI, “c”) e o artigo 458 do mesmo dispositivo normativo determina que o poder público deve "garantir que as informações chegue a todos os cidadãos e dar condições para que estes possam discutir os projetos e participar de suas soluções".

Entretanto ao analisar o caso verifica-se que o Poder Público além de não apresentar previamente os motivos idôneos que fundamentaram a remoção, não realizou o exercício ponderativo entre os interesses envolvidos tampouco observou as normas exigidas em caso de remoção.

\subsection{Vila Autódromo e o projeto "Cidade negócios".}

O capítulo 2 evidenciou que a política urbana brasileira pautou-se em um projeto de elitização e mercantilização da cidade objetivando a garantia de interesses de determinados grupos econômicos. Nesse sentido, as práticas remocionistas adotadas pelo Poder Público carioca em diferentes momentos da história foram utilizadas para beneficiar determinadas classes e grupos econômicos- imobiliários, turísticos, gastronômicos, culturais - e para o exercício do controle social.

Não obstante a existência de justificativas diferentes e contraditórias que fundamentam a remoção da Vila Autódromo, é mister ressaltar que o processo em análise está inserido na lógica de elitização e mercantilização do espaço urbano. A remoção da Vila Autódromo é um processo que ocorre no contexto dos megaeventos, mas, sobretudo sociedade de mercado globalizada. Em tal sociedade o espaço torna-se objeto de compra e venda e das estratégias que visam impulsionar a acumulação de capital. ${ }^{170}$ Entre as

${ }^{170}$ COUTINHO, Ronaldo. A mitologia da Cidade sustentável no Capitalismo. COUTINHO, Ronaldo e BONIZZATO, Luigi, orgs.Direito à Cidade: Novas Concepções obre as Relações Jurídicas no Espaço Social. Rio de Janeiro: Lúmen Júris, 2007.p.13 
estratégias que buscam tornar a cidade "mercadoria" atraente e flexível estão aquelas que visam "embelezar" o espaço urbano. ${ }^{171}$

Essa estratégia pode ser verificada no contexto de urbanização da Barra da Tijuca, cujo objetivo, segundo Consentino, especialista em planejamento urbano, é transformar o referido bairro na "nova centralidade do Rio de Janeiro" e um "local exclusivo para população de maior poder aquisitivo da cidade." 172 Consetino afirma, ainda, que o "processo de urbanização da Barra da Tijuca reflete uma lógica de negação do público que tem como base princípios neoliberais." ${ }^{173}$

Assim, a remoção da Vila autódromo insere-se no objetivo de elitização do espaço. O empresário Carlos Carvalho, acionista da empreiteira Carvalho Hosken que participa de obras do Parque Olímpico, declarou que a Barra da Tijuca é "cidade da elite, do bom gosto" e que, por esta razão, "precisava ser moradia nobre, e não moradia para os pobres". ${ }^{174}$

Eduardo Paes criticou as declarações feitas pelo empresário ${ }^{175}$, entretanto já havia afirmado que as concessões de uso outorgadas aos moradores foram erro. ${ }^{176}$ Além disto, o plano estratégico apresentado pelo chefe do Executivo Municipal previa redução das áreas de favelas. Observase que o interesse do Poder Público em remover a Vila Autódromo enquadra-se na "higenização" da cidade.

Tal política de "higenização" no contexto dos megaeventos esportivos na cidade do Rio de Janeiro é descrita no Dossiê Nacional Comitês Populares da Copa:

“coalização de forças políticas somada aos interesses de grandes empreiteiras acelerou a "limpeza social" de áreas valorizadas da cidade, e acelerou a abertura de novas frentes lucrativas para empreendimentos de alto padrão. Trata-se de

\footnotetext{
${ }^{171}$ No subcapítulo que apresentou as justificativas apresentadas pela Prefeitura evidencia-se a "redução das favelas" como meta.

172 CONSENTINO, Renato. Barra da Tijuca e o Projeto Olímpico. Barra da Tijuca e o Projeto Olímpico: A cidade do capital.2015. pg. 144. Dissertação de Mestrado. Planejamento urbano e Regional. Universidade Federal do Rio de Janeiro. O pesquisador ao tratar do processo de urbanização da região Administrativa da Barra (abriga os bairros da Barra da Tijuca, Recreio dos Bandeirantes, Vargem Pequena, Vargem Grande, Camorim, Grumari, Joá e Itanhangá) ressalta a especulação imobiliária e a concentração fundiária da localidade, concluindo que se trata de planejamento neoliberal.

${ }_{173}$ CONSENTINO, Renato. Barra da Tijuca e o Projeto Olímpico. Barra da Tijuca e o Projeto Olímpico: A cidade do capital. pg. 144.

174 'Como é que você vai botar o pobre ali?', diz bilionário 'dono da Barra da Tijuca. Entrevista realizada por Jefferson Puff. Disponível em http://www.bbc.com/portuguese/noticias/2015/08/150809_construtora_olimpiada_jp $>$.Acesso em 21/10/2015.

175 Paes ataca 'dono da Barra': 'Não entendeu significado dos Jogos para o Rio'. Disponível em< http://www.bbc.com/portuguese/noticias/2015/08/150815_entrevista_eduardo_paes_hb_jp $>$.Acesso em 21/10/2015.

176 "É um péssimo exemplo", diz Paes sobre concessão de uso dada a famílias da Vila Autódromo. Disponível em < http://oglobo.globo.com/rio/e-um-pessimo-exemplo-diz-paes-sobre-concessao-deuso-dada-familias-da-vila-autodromo-16157084>.Acesso e 21/10/2015.
} 
uma política de relocalização dos pobres na cidade a serviço de interesses imobiliários e oportunidades de negócios, acompanhada de ações violentas e ilegais." 177

O processo de expulsão dos moradores também esconde a estratégia de satisfação de interesses imobiliários. Gabriela Silva, analisando o processo de ocupação da Barra da Tijuca afirma que a localidade, desde a década de 70, revela-se espaço cuja expansão urbana baseia-se, sobretudo, nos interesses das grandes incorporadoras imobiliárias. ${ }^{178}$ Nesse sentido, o espaço onde se localiza a Vila Autódromo é bastante cobiçado pelos grandes grupos econômicos.

Consentino afirma que há interesse do mercado imobiliário em "retirar os moradores pobres"179 da localidade. Assim, conclui que a Prefeitura do Rio age representando os interesses dos proprietários e "promotores imobiliários da Barra da Tijuca", expressando um projeto de cidade que é mediado pelo Poder Público carioca. ${ }^{180}$

Carlos Carvalho afirma que o consórcio formado por Carvalho Hosken, Odebrecht e Andrade Gutierrez irá construir empreendimentos imobiliários a partir de 2018 na localidade do Parque Olímpico. ${ }^{181}$ Declara que após as Olimpíadas $75 \%$ da área do Parque Olímpico será explorado pela iniciativa privada.

O parecer do Ministério Público apresentado nos autos da ação civil pública de $n^{\circ}$ 0081973-19.1993.8.0001 pontua algumas impropriedades encontradas pelo Tribunal de Contas do Município do Rio de Janeiro. Entre elas cita a ausência de estratégia "incluindo a adaptação e o funcionamento dos edifícios após os jogos e a ausência de definição do que será revertido, após o evento, para o domínio comum, como por exemplo, praças, ruas e demais áreas públicas" (fls. 2315).

DOSSIÊ DA ARTICULAÇÃO NACIONAL DOS COMITÊS POPULARES DA COPA. Megaeventos e Violação de Direitos Humanos no Brasil. Pg. 19. Disponível em:< http://www.apublica.org/wp-content/uploads/2012/01/DossieViolacoesCopa.pdf>, Acesso $28 \mathrm{de}$ setembro de 2015.

178 SILVA, Gabriela. O processo de ocupação da Barra da Tijuca/RJ. Problemas Ambientais, Conflitos Sócio-Ambientais, Impactos Ambientais Urbanos. Disponível em $<$ http://periodicos.bc.unicamp.br/ojs/index.php/parc/article/view/8634529/2450>. Acesso em 29 de outubro de 2015.

${ }^{179}$ CONSENTINO, Renato. Barra da Tijuca e o Projeto Olímpico. Barra da Tijuca e o Projeto Olímpico: A cidade do capital. Pg 125.

${ }^{180}$ CONSENTINO, Renato. Barra da Tijuca e o Projeto Olímpico. Barra da Tijuca e o Projeto Olímpico: A cidade do capital. Pg 128.

${ }^{181}$ Como é que você vai botar o pobre ali?', diz bilionário ‘dono da Barra da Tijuca. Entrevista realizada por Jefferson Puff. Disponível em < http://www.bbc.com/portuguese/noticias/2015/08/150809_construtora_olimpiada_jp $>$.Acesso em $21 / 10 / 2015$. 
O supramencionado parecer reforça que a remoção em análise objetiva satisfazer interesses imobiliários, in verbis: "é de conhecimento público que a Zona Oeste do Rio de Janeiro, em especial a Barra da Tijuca e Recreio dos Bandeirantes, sobre uma predatória exploração imobiliária." (fls. 2313)

Além de afirmar que as residências encontram-se no foco dos interesses imobiliários das incorporadoras, o procurador assevera que a Vila Autódromo "encontra-se localizada em área nobre, de relevante interesse, tanto para o Poder Público quanto para incorporadoras imobiliárias."

Essas estratégias foram ratificadas pelo parecer requerido pela Defensoria apresentado em 2010 (anexo 1). Este concluiu que os possíveis fundamentos para remoção da Vila Autódromo estão relacionados ao "preconceito arraigado nas elites da sociedade" o qual a comunidade representaria uma "ameaça a segurança dos Jogos" e aos interesses do capital imobiliário associado viabilização da infraestrutura olímpica. ${ }^{182}$

O arquiteto Lucas Faulhaber, coautor da obra SMH 2016: Remoções no Rio de Janeiro Olímpico, assevera que as obras públicas, seja BRTs, Parque Olímpico ou a revitalização do Porto são "moldados, justamente para viabilizar a retirada de uma favela. Não é que elas precisam sair porque o trajeto passa no meio. Não. O trajeto foi intencionalmente colocado em cima da favela". ${ }^{183}$

O pesquisador relembra as práticas remocionistas praticadas pelos governos no Rio de Janeiro e afirma que os assentamentos populares sempre foram vistos como espaços esteticamente reprováveis, não aprazíveis e que abrigam a criminalidade. Assim, a remoção da favela representa "limpeza" e valorização do espaço. Bruna Laboissiere, autora do trabalho de conclusão de curso intitulado Do planejamento estratégico ao planejamento conflitual: um estudo de caso sobre a Vila Autódromo, enfatiza que as políticas públicas do Rio utilizam áreas vazias e ocupadas por população de baixa renda em favor dos agentes privados. ${ }^{184}$

Assim, conclui-se que o "interesse público" nas remoções de favelas do Rio de Janeiro é invocado pela Municipalidade de forma maliciosa para atender interesses privados, violando, assim, as premissas teórico-normativas

\footnotetext{
182 Parecer Técnico - Vila Autódromo: O Direito à moradia , o Direito à Cidade e a Rio 2016 .Página 16.

183 Remoções na Vila Autódromo expõem o lado B das Olimpíadas do Rio. Disponível em $<$ http://brasil.elpais.com/brasil/2015/06/20/politica/1434753946_363539.html>, Acesso em $13 / 09 / 2015$

${ }^{184}$ LABOISSIERE. Brunna. Do planejamento estratégico ao planejamento conflitual: um estudo de caso sobre a Vila Autódromo. Trabalho Final de Graduação | Faculdade de Arquitetura e Urbanismo da Universidade de São Paulo. Fls. 31.
} 
que tutelam o direito de permanência e o modo de agir transparente da Administração. 


\section{Conclusão}

Favelas são vistas como espaço esteticamente "desaprazível" e que abrigam a criminalidade. Assim, a história da política urbana brasileira, mais especificamente do Rio de Janeiro, foi marcada por várias remoções cujo objetivo, segundo especialistas e estudiosos, foi de tornar o espaço urbano produto lucrativo, satisfazendo, desse modo, interesses de determinados grupos econômicos e classes sociais.

Destarte, o Poder Público carioca visando atender o projeto de mercantilização e elitização do espaço determinou e ainda determina remoções, muitas das quais, sem fundamentos prévios e sólidos. Observa-se, portanto, que a Administração Pública ordena tais remoções violando o ordenamento jurídico visando à satisfação de interesses escusos.

A remoção de assentamentos populares é ato excepcional, estando o direito de permanência amparado em extensas premissas teóricas normativas nacionais e internacionais. Assim, o ato administrativo que ordena a remoção, além de respeitar os princípios e regras atinentes à atuação da Administração deve observar os preceitos que orbitam em torno do direito a não remoção.

Entretanto constata-se que as regras e princípios não são observados, revelando, portanto, atuação arbitraria e autoritária da Administração Pública Municipal do Rio de Janeiro. Um dos casos representativos das arbitrariedades cometidas pelo Poder Público do Rio é a remoção da Vila Autódromo, assentamento popular localizado na Barra da Tijuca, existente a mais de 40 anos.

A municipalidade objetiva remover a Comunidade desde a década de 90 apresentando diferentes justificativas que foram se alterando no tempo. Entretanto, as justificativas apresentadas foram consideradas infundadas e insustentáveis por especialistas e estudiosos, muitas vezes rechaçadas por avaliações técnicas, que demostram, inclusive, a inexistência de projeto para área objeto de remoção.

Observa-se no caso em análise que a Administração reiteradas vezes apresentou motivos oscilantes e mudou suas posturas sem fundamentação idônea e publicidade prévia, ora afirmando que a Vila Autódromo seria removida por determinado motivo, ora por outro, e ora garantindo que parcelas dos moradores iriam permanecer na área, paralelamente procedendo à remoção infundada, e ora apenas removendo parcela dos moradores sem apresentar motivo algum. 
Assim, o ato administrativo de remoção da Vila Autódromo viola juridicidade, uma vez que evidencia inobservância dos preceitos constitucionais que exigem a publicidade, transparência, moralidade, boa-fé e lealdade para com os administrados e com recursos que Estado tutela.

Também representa violação ao ordenamento jurídico, pois seria imperioso que o Poder Público apresentasse previa e expressamente o projeto específico destinado à localidade e as situações fáticas que ensejaram a necessidade de remoção, uma vez que o ordenamento jurídico exige que o ato administrativo seja provido de motivo prévio e idôneo.

Os motivos aventados (quando são apesentados na mídia ou em juízo) pela Municipalidade estão relacionados ao "interesse público". Mas no contexto do sistema democrático e dos direitos fundamentais, não se pode conceber interesse público que emerja da vontade unilateral do Estado, e, para concretude seja necessária à violação do ordenamento jurídico e dos direitos fundamentais.

No sistema democrático e de direitos fundamentais o interesse público não é categoria abstrata obtida a partir de atos autoritários. O interesse que deve prevalecer é obtido a partir da ponderação razoável e racional dos direitos envolvidos e com a estrita observância dos preceitos teóricos e normativos aplicáveis ao caso.

Além disso, o direito de permanência da favela representa interesse público e expressa os anseios do constituinte originário, decorrente e municipal. Extensos instrumentos normativos (federais, estaduais e municipais) consagram tal direito, como á concessão real de uso usucapião urbana e regularização fundiária, além de expressa disposição que evidencia o interesse do legislador à urbanização das favelas e a concretização do direito à cidade, função social da posse e da cidade.

Não obstante o direito a não remoção representar interesse público, a execução do projeto menos oneroso e eficiente deve ser realizada pela Administração, tendo em vista que o Poder Público deve buscar os meios adequados, necessários e proporcionais para realização dos seus fins. Assim, o meio que gere menos restrição aos direitos fundamentais e cujas vantagens superem as desvantagens é o meio adequado para realização do fim público.

Conclui-se, assim, que a remoção da Vila Autódromo além de representar violação aos princípios constitucionais e ao direito de permanecia, destina-se, segundo especialistas, a satisfação de interesses econômicos e atendimento de um modelo de cidades "negócios". 
O presente trabalho sinaliza a necessidade de que as remoções sejam atos excepcionais e fundamentadas previamente e criteriosamente para fins de legitimação e controle do ato. Além disso, pontua a necessidade que a Administração Pública reveja o conceito de "interesse público", uma vez que este tem sido utilizado de forma arbitrária e indiscriminada para remoção das favelas cariocas.

Nesse sentido propõe que interesse público seja obtido a partir do seguinte tripé : ponderação razoável e racional dos interesses envolvidos, observância estrita do ordenamento jurídico e participação da sociedade, sobretudo da população diretamente afetada com ato público.

Ademais, é necessário que haja investigação, seja por intermédio de comissões parlamentares de inquérito ou ato por ato do Ministério Público, para apurar essas e outras violações ao ordenamento jurídico brasileiro, ao direito de permanência das favelas cariocas e aos postulados que regem o Estado Democrático de Direito Brasileiro.

Investigados, são necessárias que sejam tomadas as providências cabíveis, pois as práticas remocionistas despóticas são constantes na história do Rio de Janeiro e assolam o povo pobre que clama silenciosamente por socorro. 


\section{Referências}

ALFONSIN, Betânia de Moraes. Direito à moradia e segurança da posse no Estatuto da Cidade: Diretrizes, instrumentos e processos de gestão. Betânia de Moraes Alfolsin, Edésio Fernandes.2 $2^{\circ}$ Triagem. Belo Horizonte: Forúm, 2006.

ALFOnSIN, Jacques Távora. A Função Social da Posse como Pressuposto de Licitude Ético-Jurídico do Acesso e da Conservação do Direito à $\quad$ Terra. $\quad$ Disponível em: $<$ http://www.abda.com.br/revista18/pdf/artigos/A\%20fun $\% \mathrm{C} 3 \% \mathrm{~A} 7 \% \mathrm{C} 3$ $\%$ A3o.pdf $>$. Acesso 10/10/2015.

ARANTES, Otília; VAINER, Carlos B. e MARICATO, Ermínia. A Cidade do Pensamento Único: Desmanchando Consensos. Petrópolis, RJ: Vozes, 2000. p. 78.

ÁVILA, Humberto Bergmann. Teoria dos Princípios: da definição à aplicação dos princípios jurídicos. São Paulo: Malheiros, 2004.

BAPTISTA, Patrícia Ferreira. Transformações do Direito Administrativo. Rio de Janeiro: Renovar, 2003.

BINENBOJM, Gustavo. Uma teoria do direito administrativo, democracia e constitucionalização, $3^{\mathrm{a}}$ ed. revista e atualizada. Rio de Janeiro: Renovar, 2014.

BONIZZATO, Luigi (Coord.). Direito à Cidade: Novas Concepções sobre as Relações Jurídicas no Espaço Social Urbano. Rio de Janeiro: Ed. Lumen Juris, 2007.

BRUM, Mario Sergio. Memórias da Remoção: O incêndio da praia do Pinto e a "culpa" do governo. Disponível em: $<$ http://www.encontro2012.historiaoral.org.br/resources/anais/3/1339790201 _ARQUIVO_MemoriasdaRemocaoABHO2012.pdf $\wedge$. Acesso em 26/09/2015.

CANOTILHO, José Joaquim Gomes. Direito Constitucional. 7 ed. Coimbra: Livraria Almedina, 2000.

CONSEntino, Renato. Barra da Tijuca e o Projeto Olímpico. Barra da Tijuca e o Projeto Olímpico: A cidade do capital. 2015. Dissertação de Mestrado. Planejamento urbano e Regional. Universidade Federal do Rio de Janeiro

COUTINHO, Ronaldo e BONIZZATO, Luigi, orgs. Direito da Cidade: Novas Concepções Sobre as Relações Jurídicas no Espaço Social Urbano. Rio de Janeiro: Lúmen Júris, 2007

DI PIETRO, Maria Sylvia Zanella. Direito administrativo. 23. ed. São Paulo: Atlas, 2010. 
O Principio da Supremacia do

Interesse

Público.

Disponível

em: $<$ http://www.bidforum.com.br/bid/PDI00006.aspx?pdiCntd=62095. $>$ Ace sso em 21/11/2015.

FAGUNDES, Miguel Seabra. O Controle dos Atos Administrativos pelo Poder Judiciário. 8. ed. Rio de Janeiro: Forense, 2010.

FAÇANHA ROCHA, Ludiana Carla Braga e Márcio Augusto de Vasconcelos Diniz. A Administração Pública e o Princípio da Confiança Legítima. Disponível em $<$ http://www.egov.ufsc.br/portal/sites/default/files/anexos/32601-39843-1PB.pdf $>$. Acesso em :14/09/2015.

GASPARINI, Diógenes. Direito Administrativo. 8. ed. São Paulo: Saraiva, 2003.

GODOY, Claudio Luiz Bueno de. Função Social do Contrato. São Paulo: Saraiva, 2004, p. 100.

HAMNET, 1984 apud BIDOU ZACHARIANSEN (org). De Volta à Cidade: dos Processos de Gentrificação às Políticas de "Revitalização" dos Centros Urbanos. São Paulo: Annablume, 2006.

LABOISSIERE. Brunna. Do Planejamento Estratégico ao Planejamento Conflitual: Um Estudo de Caso Sobre a Vila Autódromo. Trabalho Final de Graduação . Faculdade de Arquitetura e Urbanismo da Universidade de São Paulo.

LIMA DA SILVA, Diego de Toledo. Históricas e Atuais Práticas de Higienização Social. Disponível em $<$ http://racismoambiental.net.br/2013/01/19/historicas-e-atuais-praticas-dehigienizacao-social/>. Acesso em 26/09/2015.

\begin{tabular}{cclll}
\multicolumn{2}{c}{ LIRA, Ricardo Pereira. } & Direito Formal e direito & Informal nos \\
Centros & Urbanos. & Disponível & em $<$ & $\mathrm{http}: / / \mathrm{www} . \mathrm{e}-$
\end{tabular} publicacoes.uerj.br/index.php/rdc/article/viewFile/16963/12760>. Acesso em 12/09/2015.

MADUREIRA, Claudio Penedo. Supremacia do Interesse Público Sobre Privado: Uma Necessária Desconstrução Crítica. Forúm Administrativo-FA, Belo Horizonte, ano 14, n161 ,p9-24, jul.2014

MAGALHÃES, Alexandre. Transformações no "problema favela" e a Reatualização da Remoção no Rio de Janeiro. Tese de Doutorado Sociologia. Universidade do Estado do Rio de Janeiro,2013.

MAZZUOLI, Valério de Oliveira. Curso de Direito Internacional Público, 3 ed. rev., atual. ampl. São Paulo: Revista dos Tribunais, 2008, p. 113.

MELlO, Celso Antônio bandeira de. Curso de Direito Administrativo,28 ed.São Páulo:Medeiros,2011. 
MENDES, Alexandre F. A Atualidade do Comunismo. A produção do comum no pensamento político de Toni Negri. Disponível em: < http://www.e-publicacoes.uerj.br/index.php/revistaceaju/article/view/3547 >. Acesso em 12/09/2015.

MENDES, Gilmar Ferreira Mendes. Direitos Fundamentais e Controle de Constitucionalidade. São Paulo: Celso Bastos Editor, 1988.

NABACK, Clarissa Pires de Alemida. Remoções biopolíticas: o habitar e a resistência da Vila Autódromo. Rio de Janeiro, 2015. Dissertação de Mestrado-Departamento de Direito. Pontifícia Universidade Católica do Rio de Janeiro.

NEGREIROS, Teresa. Fundamentos para uma Nova Interpretação Constitucional do Princípio da Boa-Fé. Rio de Janeiro: Renovar, 1998.

OLIVEIRA, Marcelo Andrade Cattoni de. Direito Constitucional. Belo Horizonte: Mandamentos,2002. p. 57-58.

PETERLI, Rebeca. Função Social da Cidade e Gestão Democrática Urbana: Estudo do "Projeto Porto Maravilha". Disponível em: $<$ http://www.pucrio.br/pibic/relatorio_resumo2013/relatorios_pdf/ccs/DI R/DIR-Rebeca\%20Peterli.pdf.> Aceso em 26/09/2015.

PETERLI, Rebeca. Gentrificação : Abordagem Jurídica no estudo do projeto "Porto Maravilha". Disponível em: $<$ http://www.pucrio.br/pibic/relatorio_resumo2014/relatorios_pdf/ccs/DIR/DIR-

Rebeca_Peterli.pdf $>$. Acesso em 26/09/2015.

PIQUET, Rosélia. Cidade-Empresa: Presença na Paisagem Urbana Brasileira. Rio de Janeiro: Jorge Zahar Editor,1998.

PONTES. Maria Lúcia de. Comunidade Indiana - Programa Minha Casa Minha Vida: Incentivo à política habitacional ou mecanismo de estímulo a remoção na cidade do Rio de Janeiro. In: Os Conflitos fundiários no Brasil: estratégias de luta contra os despejos e empoderamento a partir da teoria crítica de direitos humanos. Organizadores: Cristiano Muller, Karla Fabrícia Moroso dos Santos Azevedo. Porto Alegre: CDES Direitos Humanos,2014.

ROLNIK, Raquel. Estádios e Negócios Imobiliários: já perdi a conta de em que capítulo está essa novela... Disponível em: < https://raquelrolnik.wordpress.com/2011/10/28/estadios-e-negocios imobiliarios-ja-perdi-a-conta-de-em-que-capitulo-esta-essanovela/\#comments>, acesso em 28/09/2015.

SARMENTO, Daniel. A Ponderação de Interesses na Constituição Federal, $1^{\circ}$ ed., $3^{\circ}$ tir. Rio de Janeiro: Lumen Juris, 2003.

SARMENTO, Daniel (org) Interesses públicos versus interesses privados: descontruindo o princípio da supremacia do interesse público. Rio de Janeiro: Lumen Juris, 2005. 
SAULE JÚNIOR, Nelson. A proteção jurídica da moradia nos assentamentos irregulares. Porto Alegre: Sergio Antônio Fabris Editor, 2004.

SCHREIBER, Anderson. A proibição do comportamento contraditório. Tutela da confiança e venire contra factum proprium. Rio de Janeiro: Renovar, 2005.

SILVA, Gabriela. O processo de ocupação da Barra da Tijuca/RJ. Problemas Ambientais, Conflitos Sócio-Ambientais, Impactos Ambientais Urbanos. Disponível em: $<$ http://periodicos.bc.unicamp.br/ojs/index.php/parc/article/view/8634529/24 50>. Acesso em 29 de outubro de 2015.

SIMAS. Luiz Antônio. Históricas e atuais práticas de higienização social. Disponível em $<$ http://racismoambiental.net.br/2013/01/19/historicas-e-atuais-praticas-dehigienizacao-social/>.Acesso em 26/09/2015

TEIXEIRA, Bruno Cesar Gonçalves. Obrigatoriedade de motivação dos atos administrativos. In: Âmbito Jurídico, Rio Grande, XII, n. 65, jun 2009. $<$ http://www.ambitojuridico.com.br/site/index.php?n_link=revista_artigos_1 eitura\&artigo_id=6131>. Acesso em 30 de outubro de 2015.

TORRES, Marcos Alcino de Azevedo. Posse e Propriedade. Rio de Janeiro, Lumen Juris, 2006, p. 295-317.

WERNECK, Augusto. República, Democracia e os princípios Constitucionais da Administração Pública: $O$ caso do nepotismo e a permanência do patrimonialismo. Disponível em: < http://www.cis.pucrio.br/cis/cedes/PDF/09julho/republica $\% 20 \mathrm{e} \% 20$ impessoalidade_augusto $\% 2$ 0werneck.pdf $>$. Acesso em 12/09/2015.

\section{Legislação}

BRASIL, Constituição da República Federativa do(1988). Disponível em: < http://www.planalto.gov.br/ccivil_03/Constituicao/Constituicao.htm>. Acesso em 12/09/2015.

BRASIL, Lei 10.257, de 10 de julho de 2001. Estatuto da Cidade. Disponível

em: $<$ http://www.planalto.gov.br/ccivil_03/leis/LEIS_2001/L10257.htm>. Acesso em 12/09/2015.

BRASIL, Lei $\mathrm{n}^{\circ} 11.977$, de 7 de julho de 2009, que dispõe sobre Minha Casa Minha Vida”. Disponível em: $<$ http://www.planalto.gov.br/ccivil_03/_ato2007-

2010/2009/lei/111977.htm>. Acesso em 12/09/2015.

BRASIL, Lei Federal n. 11.124, de 16/06/2005, que dispõe sobre o Sistema Nacional de Habitação de Interesse Social. Disponível em: < 
http://www.planalto.gov.br/ccivil_03/_ato2004-2006/2005/lei/111124.htm>. Acesso em 12/09/2015.

RIO DE JANEIRO (Estado), Constituição do. Disponível em: < http://www.alerj.rj.gov.br/processo6.htm.> Acesso em 12/09/2015.

RIO DE JANEIRO (Município),Lei Orgânica do. Disponível em: $<$ http://www2.rio.rj.gov.br/pgm/leiorganica/leiorganica.html> Acesso em 12/09/2015.

RIO DE JANEIRO (Município) Plano Diretor do Munícipio do Rio de Janeiro, Lei Complementar n. ${ }^{\circ} 111$ de $1^{\circ}$ de fevereiro de 2011. Disponível em:<

http://mail.camara.rj.gov.br/APL/Legislativos/contlei.nsf/a99e317a9cfec383 032568620071f5d2/cdd6a33fa14df524832578300076df48?OpenDocument> Acesso em 12/09/2015.

RIO DE JANEIRO (Estado), Lei Complementar $\mathrm{n}^{\circ} 74$,de 14 de Janeiro de 2005. Disponível em:< http://mail.camara.rj.gov.br/APL/Legislativos/contlei.nsf/1dd40aed4fced2c5 032564ff0062e425/6ac956bdce1be32d032577220075c824?OpenDocument $>$ .Acesso em 12/09/2015.

RIO DE JANEIRO(Munícipio).Decreto $n^{\circ} 34522$ de 3 de outubro de 2011.Disponível em: $<$ http://doweb.rio.rj.gov.br/ler_pdf.php?edi_id=381\&page=3>. Acesso em 12/09/2015.

RIO DE JANEIRO (Município). Decreto n. 39851 de 18/03/2015, Decreto 39852 de 18/03/2015 e Decreto n. 39853 de 18/03/2015.

Comentário Geral $\quad \mathrm{n}^{\circ} 4 . \quad$ Disponível em $<$ http://www.unhchr.ch/tbs/doc.nsf/(Symbol)/469f4d91a9378221c12563ed0 053547e?.Opendocument $>$. Acesso em 10/09/2015

\section{Sites visitados}

Site das Nações Unidas. Eventos esportivos no Brasil ameaçam direito à moradia, diz relatora da ONU. Disponível em: $<$ http://nacoesunidas.org/eventos-esportivos-no-brasil-ameacam-direito-amoradia-diz-relatora-da-onu/.>Acesso em 20/09/2105.

Site do Comitê Popular da Copa e Olímpiadas: Dossiê reúne denuncias de violações de direitos humanos no Rio de Janeiro. Publicado em 18/04/2012. Disponível em:< https://comitepopulario.wordpress.com/tag/relatoria-da-onu-pelo-direito-amoradia-adequada/>.Acesso em 20/09/2015.

Dossiê da articulação dos Comitês Populares da Copa. Megaeventos e Violação de Direitos Humanos no Brasil. Disponível em:< http://www.apublica.org/wpcontent/uploads/2012/01/DossieViolacoesCopa.pdf $>$.Acesso 28 de setembro de 2015 
Dossiê do Comitê Popular da Copa e Olímpiadas do Rio de Janeiro. Megaeventos e violação de direitos humanos no Rio de Janeiro. Junho de 2014. Disponível em < https:/comitepopulario.files.wordpress.com/2014/06/dossiecomiterio2014_ web.pdf $>$.Acesso em 28/09/2015.

Informe da Relatora Especial sobre moradia adequada disponível em $<$ https://raquelrolnik.files.wordpress.com/2010/11/mega_eventos_portugues 1.pdf $>$ acesso em 30/09/2015.

Plano Popular da Vila Autódromo. Disponível em: $<$ https://comitepopulario.files.wordpress.com/2012/08/planopopularvilaauto dromo.pdf $>$.Acesso em 12/10/2015.

Eduardo Paes Mente! Moradores da Vila Autódromo lutam para não sair. Disponível em $<$ https://www.youtube.com/watch?v=5w3YbHqmL$0>$.Acesso em 18/10/201.

Vila Autódromo sobre com os impactos das Obras Olímpicas. Disponível em: https://www.youtube.com/watch?v $=W R G \_$_KMhiM\&feature $=$share $>$. Acesso em 09/11/2015.

Nota pública: Vila Autódromo conquista sua permanência. Disponível em $<$

https://comitepopulario.wordpress.com/2013/08/09/nota-publica-vilaautodromo-conquista-sua-permanencia/>.Acesso em 18/10/201.

Vila Autódromo Unida em um ato após semana de pressão. Disponível em : <http://rioonwatch.org.br/?p=7034. >.Acesso em 29/09/2015

\section{Entrevistas}

Leonardo Chaves em entrevista ao Eduardo Sá. Disponível em:< http://www.barracoadentro.com/\%E2\%80\%9Cnao-esta-havendo-umprocesso-de-desapropriacao-o-que-esta-havendo-e-um-processo-deespoliacao\%E2\%80\%9D/>.Acesso em 19/09/2015.

Clarissa Naback em entrevista ao Institutio Humanita Unisinos. Disponível em: $<$ http://www.ihu.unisinos.br/entrevistas/543294-vilaautodromo-desapropriacoes-ocorrem-ao-largo-de-processos-judiciaisentrevista-especial-com-clarissa-pires-naback. >. Acesso em 20/09/2015.

Paula Paiva Ribeiro em entrevista à Publica. Ponha-se na Rua : Há 200 anos é assim que o governo lida com as comunidades cariocas. Disponível em :<file://C:/Users/raquel/Downloads/ponha-se-na-rua-maisde-200-anos-de-remocoes-compulsorias-rio-de-janeiro.pdf. $>$. Acesso em $18 / 09 / 2015$.

Prefeito Eduardo Paes em entrevista à BBC Brasil. Paes ataca 'dono da Barra': 'Não entendeu significado dos Jogos para o Rio'. Disponível em:< http://www.bbc.com/portuguese/noticias/2015/08/150815_entrevista_eduard o_paes_hb_jp>.Acesso em 24/10/2015. 
Carlos Carvalho em entrevista à BBC Brasil (Entrevista realizada por Jefferson Puff ). Como é que você vai botar o pobre ali?’, diz bilionário 'dono da Barra da Tijuca.. Disponível em < http://www.bbc.com/portuguese/noticias/2015/08/150809_construtora_olim piada_jp>.Acesso em 21/10/2015.

\section{Reportagens}

Caminhos Divergentes: Moradores da Vila Autódromo Resistem, Seguem o Caminho, ou Aguardam. 15 de agosto de 2014. Disponível em< http://rioonwatch.org.br/?p=12090>, acesso em 16 de setembro de 2015.

Moradores da Vila Autódromo se mudam para Parque Carioca. Disponível em $:<$ http://oglobo.globo.com/rio/bairros/moradores-da-vilaautodromo-se-mudam-para-parque-carioca-1-12058290>.Acesso em 28/10/2014.

Plano estratégico: Paes quer reduzir e 3,5\% total da área de favelas até 2012. Disponível em $:<$ http://extra.globo.com/noticias/rio/planoestrategico-paes-quer-reduzir-em-35-total-da-area-de-favelas-ate-2012207796.html\#ixzz3kWxd9aCS> Acesso em 09 de outubro de 2015.

\section{Disponível}

Plano Olímpico para Rio-2016 prevê a remoção de favelas. em: $<$ http://www1.folha.uol.com.br/paywall/login.shtml?http://www1.folha.u ol.com.br/fsp/esporte/fk0810200906.htm>.Acesso em 26 de agosto de 2015.

Prefeitura removerá 119 favelas até o fim de 2012. Disponível em $<$ http://oglobo.globo.com/rio/prefeitura-removera-119-favelas-ate-fim-de2012-3072053>.Acesso em 10/09/2015.

Prefeito Eduardo Paes fala sobre remoção de famílias da Vila Autódromo. Publicado em 21 de novembro de 2012. Disponível em < http://www.radiobetel $98 \mathrm{fm} . c 0 m . b r / n o v o / 2012 / 11 / 21 /$ prefeito-eduardo-paesfala-sobre-remocao-de-familias-da-vila-autodromo/>.Acesso e 5 de fevereiro de 2013.

Remoções na Vila Autódromo expõem o lado B das Olimpíadas do Rio. Disponível em $<$ http://brasil.elpais.com/brasil/2015/06/20/politica/1434753946_363539.ht ml>.Acesso em 13/09/2015.

É um péssimo exemplo, diz Paes sobre concessão de uso dada a famílias da Vila Autódromo. Disponível em < http://oglobo.globo.com/rio/eum-pessimo-exemplo-diz-paes-sobre-concessao-de-uso-dada-familias-davila-autodromo-16157084>.Acesso em 21/10/2015.

Riscos, pressão e escombros: A rotina de quem desafia as remoções da Rio-2016. Disponível em: $<$ http://www.bbc.com/portuguese/noticias/2015/03/150305_rio2016_vila_au todromo_rm_jp $>$. Acesso em 21/10/2015. 
Mudança de 80 famílias provoca protesto em moradores de Curicica. O Globo , 01 de março de 1987,Caderno,p.16

Visita antes da decisão. $O$ Globo, 24 de outubro de 2013, jornal do bairro, página 8 .

Felicidade a $1 \mathrm{~km}$ de distância. $O$ Globo, jornal do bairro,03 de abril de 2014,página 6

\section{Processos judiciais (e documentos acostados aos autos - processos eletrônicos e digitalizados)}

Ação Civil Pública, Restituição de área/Intervenção do Estado na Propriedade. $4^{\circ}$ Vara de Fazenda Pública, Comarca da Capital do Estado do Rio de Janeiro. Autos do processo $\mathrm{n}^{\circ}$ 1993.001.078414-7 (008197319.1993.8.19.0001).

Ação Cautelar Inominada, Antecipação de Tutela E/ou Obrigação de Fazer Ou Não Fazer Ou Dar. $5^{\text {a }}$ Vara da Fazenda Pública, Comarca da Capital do Estado do Rio de Janeiro. Autos do processo $n^{\circ} 0013864-$ 83.2012.8.19.0001.

Ação Civil Pública, Antecipação de Tutela E/ou Obrigação de Fazer Ou Não Fazer Ou Dar. $5^{\text {a }}$ Vara da Fazenda Pública, Comarca da Capital do Estado do Rio de Janeiro. Autos do processo n 0075959-18.2013.8.19.0001.

Ação Civil Pública, Moradia $\mathrm{C} / \mathrm{C}$ Anulação/nulidade de Ato Administrativo / Atos Administrativos C/C Ordenação da Cidade / Plano Diretor / Domínio Público. 13 ${ }^{\mathrm{a}}$ Vara de Fazenda Pública, Comarca da Capital do Estado do Rio de Janeiro. Autos do processo $n^{\circ}$ 015968698.2015.0001.

\section{Julgados}

STJ, MS 15.290/DF, Rel. Min. Castro Meira, julgado em 26.10.2011, DJe 14.11.2011.

STJ, AgRg no REsp 1280729 /RJ, Rel. Min. Humberto Martins, julgado em 10/04/2012, DJe 19/04/2012.

STF: RE (M.C.) 2.900/RS, Rel. Min. Gilmar Mendes, julgado em 37/05/2003 (Informativo 310).

STJ: REsp 709.934/RJ , Rel. Min Humberto Martins, julgado em 21/06/2007.

TJ/ RJ, Apelação n ${ }^{\circ}$ 2006.001.44440, Rel. Des. Azevedo Pinto (13 Câmara Civil) , julgamento em 13/12/2006. 


\section{Anexos}

Anexo 1- Parecer técnico -Vila Autódromo: o Direito à Moradia, o Direito à Cidade e a Rio 2016.

Anexo 2 - Tabela que sistematiza os gastos com indenizações com moradores da Vila Autódromo. 


\section{Parecer Técnico *}

\section{Vila Autódromo: o Direito à Moradia, o Direito à Cidade e a Rio 2016}

1. O objetivo desse Relatório é o de subsidiar a Defensoria Pública no que se refere aos questionamentos a serem formulados quanto à intenção manifestada pela Prefeitura do Rio de Janeiro de remover a Comunidade da Vila Autódromo em função da realização dos Jogos Olímpicos de 2016.

2. A Comunidade da Vila Autódromo está situada na Avenida Embaixador Abelardo Bueno, 977, na Barra da Tijuca. Essa área é ocupada pela comunidade desde 1985, tendo sido declarada como Área de Especial Interesse Social em 2005, por meio da Lei Complementar n 74/2005. Atualmente residem no local cerca de 900 famílias.

A permanência das famílias nessa área está apoiada em diversos instrumentos juridicos, entre os quais, os Termos Administrativos de Concessão de Uso concedido pelo ITERJ - Instituto de Terras e Cartografia em nome do Estado do Rio de Janeiro, por ser este o titular da área onde está localizada a comunidade.

Além disso, cabe citar que o direito social à moradia é garantido pela Constituição Federal e que o Estatuto da Cidade - Lei 10.257/2001 e a Lei Orgânica do Municipio estabelecem como uma das diretrizes da política de desenvolvimento urbano a regularização fundiária e a urbanização de áreas ocupadas por população de baixa renda.

3. A comunidade tem sofrido constantes ameaças de remoção, que tem sua origem na última década, conforme registrado no documento distribuído durante o Fórum Social Urbano, realizado no Rio de janeiro de 23 a 26/3/2010:

"A primeira [tentativa de remoção] ocorreu em 1992, quando o Município do Rio de Janeiro alegou "dano estético e ambiental" em ação judicial ajuizada no Tribunal do Rio de Janeiro requerendo a retirada total da comunidade. A Barra da Tijuca, então, despontava como nova centralidade para empreendimentos imobiliários, comerciais e esportivos, exigindo, como bem traduziu o procurador do município, uma nova "estética", na qual os pobres não estavam incluidos." 1

\footnotetext{
1 "Rio de Janeiro: Olimpíadas para todos, sem remoção! - A mais recente luta da Comunidade Vila Autódromo" - Associação de Moradores de Vila Autódromo e Núcleo de Terras e Habitação Defensoria Pública do Estado do Rio de Janeiro - Março de 2010 - disponível em "http://www.piratininga.org.br/novapagina/leitura.asp?id_noticia=5864\&topico=Cidades"
} 
4. Desde o anúncio da escolha do Rio de Janeiro como sede dos Jogos Olímpicos de 2016 foram apresentadas diferentes argumentos para justificar a necessidade de remoção da Comunidade da Vila Autódromo, os quais serão relatados nos itens a seguir.

5. Em $8 / 10 / 2009$, a prefeitura anunciou que, para viabilizar a realização dos Jogos no Rio de Janeiro em 2016, seria necessária a remoção² de mais de 3.500 familias de seis favelas das zonas oeste e norte da cidade. As comunidades listadas pela prefeitura, na ocasião, foram: Vila Autódromo, Canal do An̉il, Gardênia Azul, Parque da Panela, Metrô-Mangueira e Belém-Belém. Com relação à Vila Autódromo, especificamente, de acordo com o plano da prefeitura "o local servirá para ampliação de duas avenidas que circundam a favelà (avenidas Embaixador Abelardo Bueno e Salvador Allende): Outro motivo, acrescentado pelo prefeito Eduardo Paes, seria a construção, nesse local, do Centro de Midia ${ }^{3}$.

6. Em 5/12/2009, o prefeito Eduardo Paes anunciou o seu Plano Estratégico de Governo 20092012, contendo 46 metas, entre as quais a de "reduzir em 3,5\% as áreas ocupadas por favelas no Rio" (1,6 milhão de metros quadrados, "o equivalente a duas Rocinhas", conforme o parâmetro utilizado pelo prefeito). Posteriormente, em 7/1/2010, a Secretaria Municipal de Habitação divulgou uma relação com 119 favelas "que serão removidas integralmente pela prefeitura até o fim de 2012, por estarem em risco de deslizamento ou inundação, de proteção ambiental ou destinados a logradouros públicos... Entre as favelas que vão desaparecer estão a do Horto (Jardim Botânico), a Indiana (Tijuca), a da CCPL (Benfica), a do Metrô (Maracanã), a Vila Autódromo (Barra) e a Vila Taboinhas (Vargem Grande)"4.

7. A Comunidade da Vila Autódromo mobilizou-se para resistir a mais essa nova tentativa de remoção desde outubro de 2009 , processo que culminou com a realização de uma expressiva manifestação em frente à sede da prefeitura, na Cidade Nova, no dia 10/2/2010. Nessa ocasião

\footnotetext{
${ }^{2}$ O conceito de "remoção" não encontra respaldo no ordenamento jurídico brasileiro que, como desdobramento do direito social à habitação, inscrito na Constituição Federal, inclui entre as diretrizes que devem nortear a política de desenvolvimento urbano a regularização fundiária e a urbanização de áreas ocupadas por população de baixa renda e o princípio da gestão democrática. Assim, o reassentamento de famílias (e não a "remoção") é admitido somente quando as condições físicas da área ocupada imponham risco de vida a seus habitantes, ou seja, em situações bastante específicas e localizadas. No caso, manteve-se a utilização do termo no presente parecer porque esse, de fato, expressa a concepção que vem sendo difundida e defendida pelo prefeito e outras autoridades públicas, em descordo com a legislação vigente.

3: "Plano Olímpico para Rio-2016 prevê a remoção de favelas" - Folha de São Paulo - 08/10/2009.

4j “Plano Estratégico: Paes quer reduzir em 3,5\% total da área de favelas até 2012" - O Globo on-line 05/12/2009;

"Prefeitura do Rio pretende retirar mais de 12 mil familias de áreas de risco" - O Globo on-line 06/01/2010; e

"Prefeitura removerá 119 favelas até o fim de 2012" - O Globo on-line - 07/01/2010.
} 
o prefeito recebeu uma comissão de representantes e, mesmo reafirmando a intenção de remover a comunidade, o que seria uma "exigência do Comitê Olímpico Internacional", admitiu que o processo apresentaria "falhas" - como, por exemplo, o fato de o "projeto olímpico" não ter sido discutido com a população - e acenou com a possibilidade de abertura de um diálogo entre a prefeitura e a comunidade para avaliar possiveis alternativas.

8. No dia $3 / 3 / 2010$, foi realizada reunião entre o Prefeito, O Secretário de Habitação, representantes da comunidade, a Defensoria Pública e outros segmentos que tem apoiado a comunidade na luta contra a remoção. Nessa reunião o prefeito reafirmou a disposição de dialogar com a comunidade, mas deixou claro que a proposta da prefeitura era de que a comunidade fosse transferida para localidades próximas, já tendo, inclusive, verificado a possibilidade de utilização de alguns terrenos localizados em bairros vizinhos. Nessa reunião o Secretário de Habitação acrescentou um novo argumento para justificar a proposta de remoção da comunidade, que seria a impossibilidade técnica de realização das obras de saneamento, em razão de a área estar localizada entre dois rios (sic). Os representantes da Comunidade Vila Autódromo reafirmaram sua disposição em continuar lutando pelo direito de permanecer na área, solicitando, ao final da reunião, que a prefeitura apresentasse o projeto oficial aprovado pelo COI para que a comunidade pudesse conhecer os reais fundamentos da proposta anunciada pelo prefeito, sendo agendada nova reunião com esse objetivo.

9. No dia 30 de março de 2010, foi realizada nova reunião entre o Secretário Especial da Rio 2016, Ruy César, o Secretário de Habitação, Jorge Bittar, o Subsecretário de Habitação Pierre Batista, o Diretor de Planejamento da $\mathrm{SMH}$, Augusto Verissimo e outros funcionários da prefeitura; e os representantes da Comunidade da Vila Autódromo - Jane Nascimento e Altair Guimarães; da Defensoria Pública - Defensores Maria Lúcia de Pontes e Alexandre Mendes; da equipe técnica de apoio à Defensoria - Arquiteto e Urbanista Canagé Vilhena; do Núcleo Piratininga e da Comunidade Pitimbú. A reunião foi dividida em duas partes.

Na primeira parte, o secretário especial Rui César fez uma apresentação em PowerPoint, que tinha como objetivo mostrar a fundamentação política para a Prefeitura do Rio remover a comunidade. Depois de mostrar um panorama geral do planejamento que fez parte do Dossiê 2016, apresentado ao COl, o secretário finalizou mostrando o que seria o principal motivo para a remoção: as condições de segurança que deveriam ser garantidas pela criação de uma área livre junto ao perímetro do Autódromo e a faixa marginal de proteção da Lagoa de Jacarepaguá que será despoluida. Segundo o secretário esta faixa de segurança foi estabelecida em "comum acordo" com a ABIN (Agência Brasileira de Inteligência). 
Como pode ser visto na figura extraída dos slides apresentados pelo Secretário Especial, 0 "perímetro de segurança" do Parque Olímpico abrange uma área que inclui apenas o núcleo da comunidade, na área mais larga do seu terreno (parte norte), enquanto a parte mais estreita (parte sul) ficou fora da faixa de segurança, mas sujeita à remoção por "questões ambientais", isto é, por estar na faixa marginal de proteção da Lagoa de Jacarepaguá. A figura mostra que ficaram de fora a sede da Associação de Vôo Livre e o conjunto residencial da Aeronáutica, situados na face leste do Autódromo.

\section{FIGURA 1}

\section{Vila Autódromo - Área de Segurança e FMP}

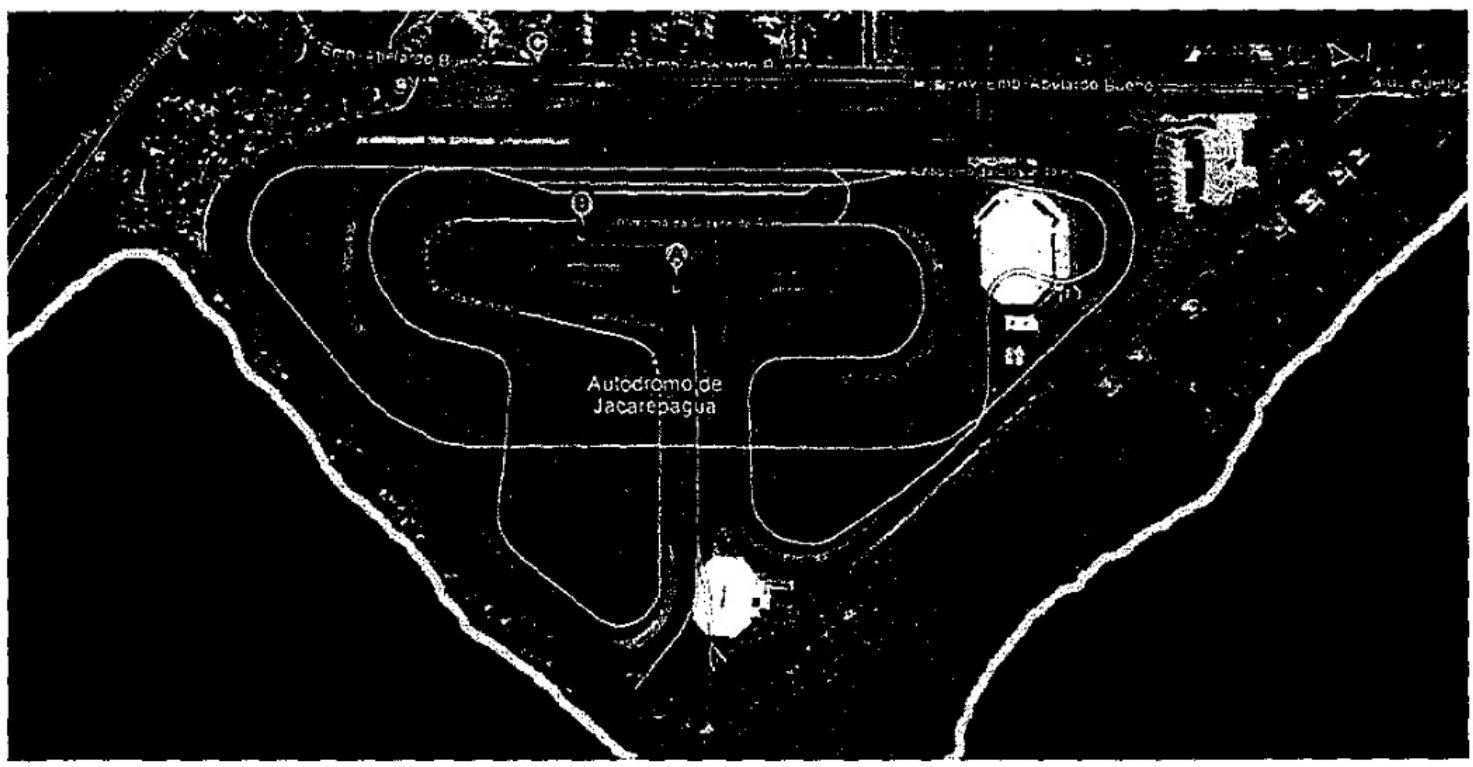

Perimetro de Segurança no Parque Olimpico

\section{Faixa Marginal de Proteção - FMP}

Fonte: "O Projeto Olimpico para o Autódromo" - Encontro com a Defensoria Pública e Lideranças da Comunidade Secretaria Especial Copa 2014 / Rio 2016-30/3/2010

Segundo o secretário especial, as propostas na área de segurança tem como objetivo resguardar, contra possiveis atentados, os atletas de diversas nações e os jornalistas que ficarão hospedados na Vila de Midia a ser construída junto ao Morro do Outeiro, em terreno próximo à comunidade 5 .

$\mathrm{Na}$ segunda parte da reunião, o Secretário de Habitaçäo Jorge Bittar respondeu às indagações dos representantes dos moradores e da Defensoria Pública. Além de deixar clara a sua determinação em atender à decisão do prefeito para remover a comunidade, o secretário, em sua exposição, destacou os seguintes pontos:

\footnotetext{
5 A Vila Olímpica, que hospedará os atletas, será localizada na face leste do Rio Centro (Avenida Salvador Allende).
} 
- O secretário ressaltou a importância do tema segurança e defendeu as "virtudes" da proposta para remoção através da elaboração de um projeto de arquitetura, que, segundo ele, não se confunde com aqueles dos tempos do Lacerda 6 . Para tanto será feito um levantamento de todas as condiçöes das habitaçöes para preservar as caracteristicas de cada uma daquelas melhores existentes, ou seja, cada caso será tratado individualmente. Assim se pretende garantir a mesma qualidade das casas mais bem acabadas. Também deixou clara a possibilidade de desapropriação com pagamentos aos proprietários como será feito no projeto para implantação do corredor T5 (BRT).

- O secretário afirmou que já existem dois outros terrenos escolhidos pela prefeitura para onde será elaborado um projeto para remoção da comunidade. Informou que já teria sido contratado um arquiteto com experiência neste tipo de trabalho (arquiteto Humberto Cerqueira), embora não houvesse um escopo definido e nem mesmo um cronograma. Segundo ainda o secretário, o projeto e seu escopo serão desenvolvidos em parceria com os moradores.

10. Vale lembrar que o objetivo dessa reunião seria a apresentação do projeto aprovado pelo $\underline{\mathrm{CO}}$, já que, até então, todos os pronunciamentos do prefeito e de outras autoridades municipais foram no sentido de que a remoção da Comunidade da Vila Autódromo seria necessária porque a área por ela ocupada seria destinada a instalações previstas para a realização dos Jogos Olímpicos. Para surpresa da comunidade, descobriu-se que, de fato, não havia previsão de qualquer instalação olimpica para a área por ela ocupada e, portanto, não havia qualquer projeto, mas que, mesmo assim, mantinha-se a exigência de que as familias fossem removidas para atender, agora, aos "requisitos de segurança" dos Jogos Olímpicos e aos condicionantes ambientais.

11. As sucessivas mudanças nos argumentos que justificariam a remoção da comunidade tornam ainda mais necessária a realização da uma investigação aprofundada sobre essa questão para que, assim, possam ser desvendados quais são as reais motivações dessa proposta e quem são os beneficiários da mesma.

12. Dessa forma, as questões que devem ser respondidas, para efeito da avaliação de alternativas, motivação original das reuniōes entre a prefeitura e a comunidade, são as seguintes: i) qual foi a proposta efetivamente apresentada ao COl; ii) no caso de confirmação da

\footnotetext{
${ }^{6}$ Trata-se do Governador Carlos Lacerda, que governou o Rio de Janeiro na primeira metade da década de 60 e que se notabilizou, entre outras açōes contra as comunidades pobres, pela execução de uma política massiva de remoções de comunidades localizadas em áreas valorizadas da cidade, e que foram transferidas para gigantescos conjuntos habitacionais localizados em bairros distantes e praticamente sem nenhuma infraestrutura.
} 
proposta de remoção da comunidade e na medida em que esta se justificasse como condição para a viabilização dos Jogos Olimpicos, se foram estudadas alternativas que pudessem, ao mesmo tempo, atender a essa necessidade e garantir o direito de as famílias permanecerem na área, entendendo que essa permanência deverá, necessariamente, ser acompanhada da realização dos investimentos em urbanização, regularização fundiária, políticas de transferência e geração de renda, etc., que proporcionem uma melhor qualidade de vida para os moradores.

13. Conforme as notícias e relatos transcritos acima, os principais argumentos apresentados pela prefeitura para a remoção da Comunidade da Vila Autódromo foram os seguintes:

a) necessidade de execução de obras de ampliação das avenidas Embaixador Abelardo Bueno e Salvador Allende;

b) necessidade de construção do Centro de Midia;

c) existência de dificuldades técnicas para a execução das obras de urbanização na comunidade;

d) localização da comunidade (parte) no perimetro de segurança do Parque Olímpico; e

e) localização da comunidade (parte) na Faixa Marginal de Proteção.

14. Todos os argumentos apresentados foram justificados em função de "exigências do Comitê Olímpico Internacional" ou das propostas incluídas no dossiê apresentado ao $\mathrm{COI}^{7}$, motivo pelo qual efetuaremos a análise de cada um desses argumentos procurando cotejá-los com 0 conteúdo desse dossiê, que constitui o documento oficial que fundamentou a candidatura do Rio de Janeiro. Cabe mencionar, ainda, a existência de dois outros documentos: um de responsabilidade da Prefeitura do Rio de Janeiro8; e outro de responsabilidade do Governo Federal ${ }^{9}$. As propostas constantes nesses outros dois documentos também serão destacadas no desenvolvimento da argumentação, cabendo destacar, preliminarmente, que o documento da

\footnotetext{
7 "Dossiê de Candidatura do Rio de Janeiro à Sede dos Jogos Olímpicos e Paraolímpicos de 2016" Conselho Executivo Rio 2016 - 3 Volumes Volume I/temas: "1. Visão, Legado e Comunicação"; "2. Conceito Geral dos Jogos Olímpicos"; "3. Clima e Estrutura da Política e da Economia"; "4. Aspectos Jurídicos"; "5. Formalidades de Alfândega e Imigração"; "6. Meio Ambiente e Meteorologia"; "7. Finanças"; e "8. Marketing" Volume IJ/temas: "9. Esporte e Instalações"; "10. Jogos Paraolímpicos"; " "11. Vila Olímpica" Volume III/temas: "12. Serviços Médicos e Controle de Doping"; "13. Segurança"; "14. Acomodações"; "15. Transporte"; "16. Tecnologia"; e "17. Operaçб̃es de Mídia"

8 "Plano de Legado Urbano e Ambiental - Olimpíadas Rio 2016" - Comitê Especial de Legado Urbano CELU

Volume I: "1. Introdução"; "2. Candidatura Olímpica no Contexto da Política Urbana"; "3. Fundamentação"; "4. Plano Macro"; "5. Planos Locais"; e "6. Bibliografia" Volume II/Anexos: "1. Fichas Plano Macro"; e "2. Fichas Planos Locais" Volume II/Cartogramas

"Cadernos de Legado: "1. Brasil - Este é o país"; “2. Legado Urbano e Ambiental”; e "3. Legado Social"

- Comitê de Gestão das Ações Governamentais Federais para a Candidatura Rio 2016
} 
Prefeitura apresenta contradições flagrantes tanto com o documento oficial apresentado ao COI como com o documento elaborado pelo Governo Federal. Passemos à análise.

\section{Necessidade de execução de obras de ampliação das avenidas Embaixador Abelardo}

\section{Bueno e Salvador Allende}

O tema "Transporte" é abordado de uma forma bastante ampla, incluindo a "estratégia de transportes e objetivos", a análise especifica sobre a rede aérea e sobre os aeroportos, a definição das autoridades responsáveis pela implantação da infraestrutura e pela operação do sistema de transporte, considerando os diferentes modais, etc. Há indicações das ações prioritárias no que se refere à infraestrutura aeroportuária, à melhoria nos sistemas de trem e de metrô, além da implantaçāo de três sistemas BRT - Bus Rapid Transit (corredor T5, Barra-Zona Sul e Ligação C), que irão conectar as zonas sul e norte da cidade à região da Barra da Tijuca. Associada à necessidade de operacionalização desses sistemas de maior porte, é especificada a necessidade de execução de obras de melhoria e extensão da rede viária, entre as quais consta o alargamento da Avenida Embaixador Abelardo Bueno e da Avenida Salvador Allende. ${ }^{10}$

Como se pode constatar na foto aérea reproduzida a seguir, a execução das obras propostas não produz qualquer interferência sobre a comunidade, destacando-se, inclusive, que, na sua face norte, a área ocupada pela Vila Autódromo é limitada pelo Rio Pavuninha, configurando, assim, uma larga faixa entre a comunidade e a via.

\footnotetext{
10 "Dossiê de Candidatura do Rio de Janeiro à Sede dos Jogos Olímpicos e Paraolímpicos de 2016" Conselho Executivo Rio 2016 / Volume III: "15. Transporte”
} 


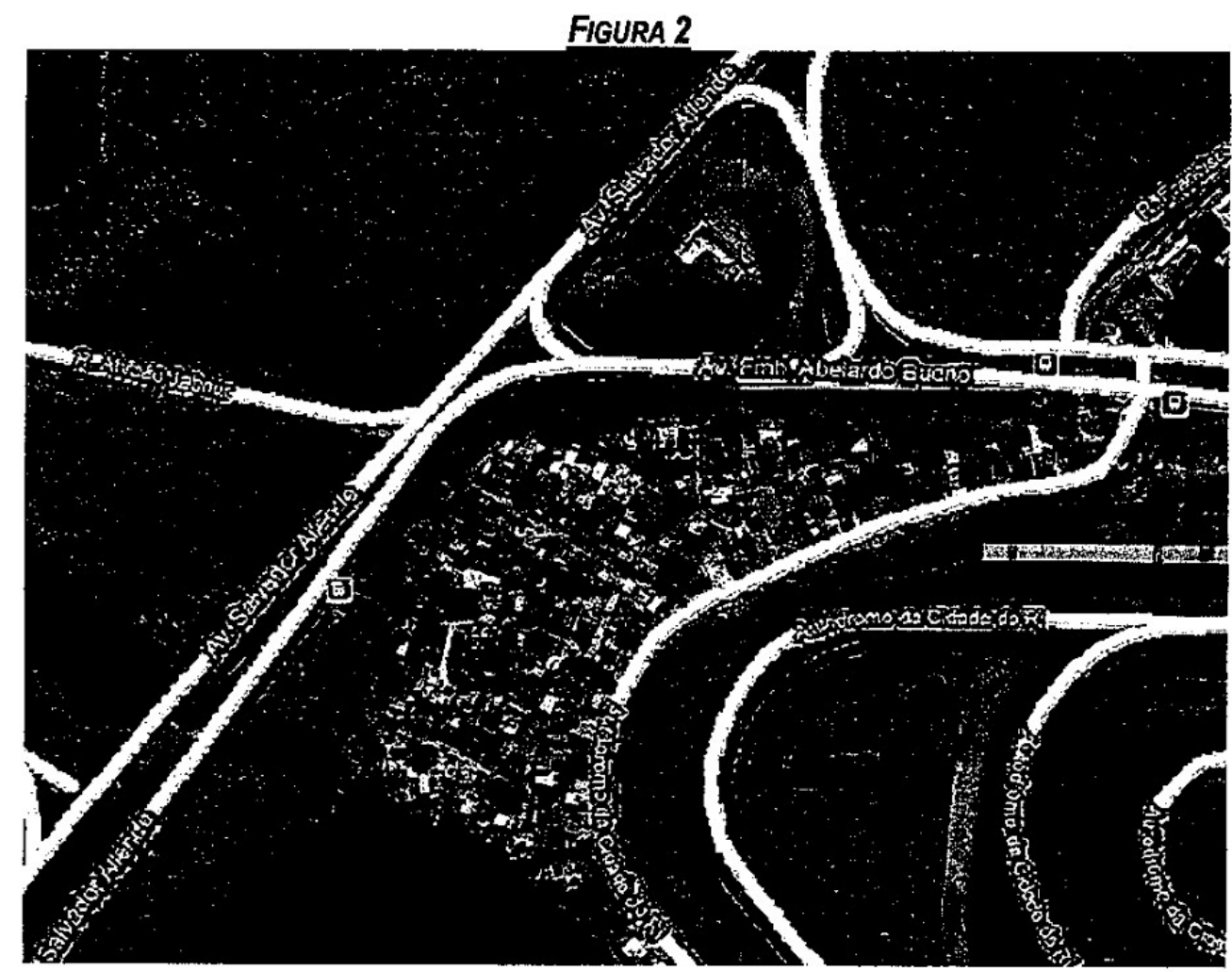

Fonte: Google maps

No entanto, as conclusões encontradas no Plano de Legado Urbano e Ambiental (PLUA) I Comitê Especial de Legado Urbano (CELU) são bastante diversas. Esse documento foi estruturado em quatro temas: "Transporte e Sistema Viário", "Meio Ambiente", "Saneamento Ambiental" e Habitação", que são abordados considerando o "Plano Macro" e os "Planos Locais", um dos quais refere-se à Região da Barra da Tijuca.

Na parte dedicada ao "Plano Macro" para o tema "Transporte e Sistema Viário", encontramos considerações gerais sobre a política de transportes, procurando relacioná-la com as diretrizes gerais de planejamento urbano, além de inúmeros mapas, diagramas, cartogramas e fotos e uma tabela na qual constam as ações previstas, acompanhadas de descrição e definição dos objetivos, dentre as quais extraímos os itens a seguir:

\begin{tabular}{|c|c|c|}
\hline Código & Acão & Objetivos/Descriçăo \\
\hline TR.5 & SISTEMA VARRIO & \\
\hline TR.5.2 & $\begin{array}{l}\text { Alargamento da Av. Salvador } \\
\text { Allende }\end{array}$ & $\begin{array}{l}\text { Aumento da capacidade da via, melhorando a fluidez dos veiculos que se deslocam entre Linha } \\
\text { Amarela/ Jacarepagual Deodoro e Barral Recreio. Inclui a implantação de } 2 \text { pistas centrais com } \\
3 \text { faixas e } 2 \text { pistas laterais com } 2 \text { faixas. Compreende cidovia ao longo do trecho, conectada à } \\
\text { cidovias existentes na vizinhança. }\end{array}$ \\
\hline TR.5.2.1 & $\begin{array}{l}\text { Reassentamento de familias } \\
\text { da Vila Autódromo }\end{array}$ & $\begin{array}{l}\text { Reassentamento de familias residentes em área de preservaçăo permanente e nas áreas } \\
\text { previstas para implantaçäo do alargamento da Av. Salvador Allende e no alargamento do trecho } \\
\text { final da Av. Abelardo Bueno e Av. Ayrton Senna. Inclui cadastro fisico e social das } 354 \text { familias } \\
\text { que serão reassentadas, com acompanhamento social, elaboraçäo de diagnóstico indicativo da } \\
\text { modalidade de reassentamento, considerando o perilil das octupaçóes e implementação do plano } \\
\text { de reassentamento. }\end{array}$ \\
\hline TR.5.3 & $\begin{array}{l}\text { Alargamento do trecho final } \\
\text { da Av. Abelardo Bueno e da } \\
\text { Av. Ayrton Senna }\end{array}$ & $\begin{array}{l}\text { Duplicaçăo do segundo trecho da Av. Abelardo Bueno, nos moldes do primeiro trecho ja } \\
\text { implantado, com } 2 \text { pistas centrais com } 3 \text { faixas e } 2 \text { pistas laterais com apenas } 2 \text { faixas (no } 1^{\circ} \\
\text { trecho há } 3 \text { faixas), aumentando a capacidade das vias, melhorando a fluidez dos veiculos que } \\
\text { se deslocam entre a Baixada de Jacarepaguá e as Zonas Norte, Suburbana e oeste da Cidade, } \\
\text { través da Linha Amarela, Corredor T5 e Ligaçăo C. }\end{array}$ \\
\hline
\end{tabular}


Fonte: "Plano de Legado Urbano e Ambiental - Olimpiadas Rio 2016" - Comitê Especial de Legado Urbano - CELU - Volume I: "4. Plano Macro".

Essas ações descritas na tabela, com seus respectivos objetivos, estabelecem uma relação inexistente entre a execução das obras de alargamento das vias e a remoção da Comunidade da Vila Autódromo, conforme se pôde constatar na Figura 2. Constata-se, assim, que o PLUAJCELU sustenta a proposta de remoção da Comunidade da Vila Autódromo, sem apresentar qualquer estudo ou justificativa baseada nas condições específicas para a execução das obras de alargamento das vias, cabendo registrar, também, que a referida proposta não possui qualquer relação com o que está proposto no documento oficial da candidatura.

\section{Necessidade de construção do Centro de Mídia}

Conforme já mencionado, a Vila de Mídia, que hospedará os jornalistas, será construída junto ao Morro do Outeiro, no outro lado da Avenida Salvador Allende, na direçäo Sudeste/Noroeste, não afetando, portanto, a área ocupada pela Comunidade da Vila Autódromo. Essa localização da Vila de Mídia, mencionada pelo prefeito em matéria veiculada pela imprensa, não é utilizada como justificativa para a proposta de remoção nem mesmo no PLUAVELU.

\section{FIGURA 3}

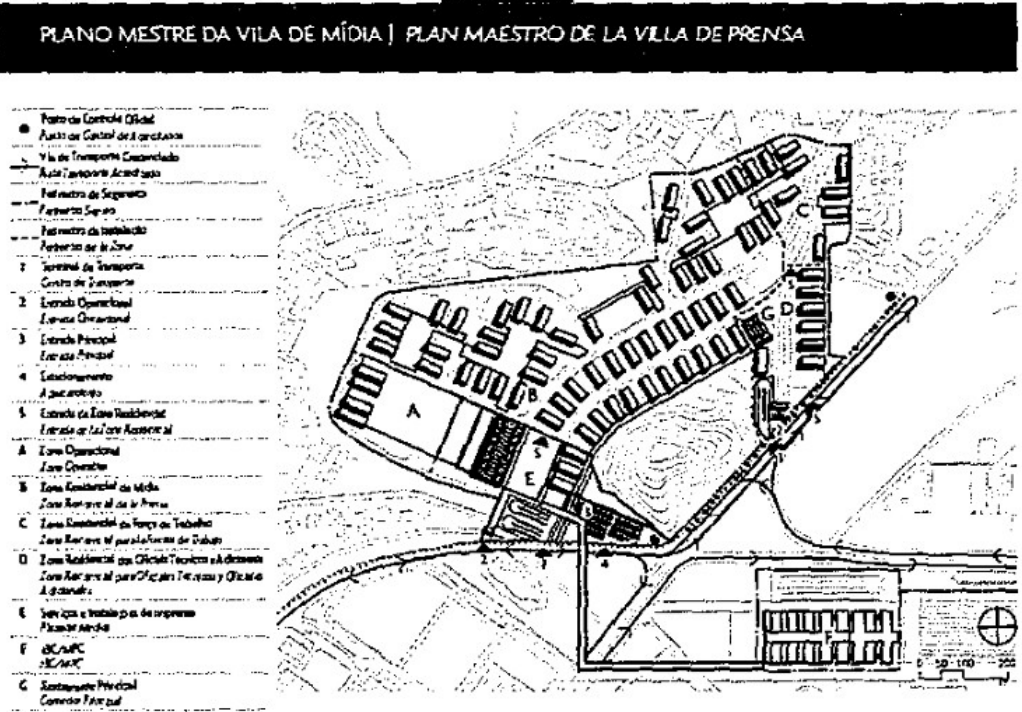

Fonte: "Dossiê de Candidatura do Rio de Janeiro à Sede dos Jogos Olimpicos e Paraolimpicos de $2016^{n}$ - Conselho Executivo Rio 2016 - Volume III: "14. Acomodaçōes"

Outro aspecto a ser considerado é que, segundo o Prefeito Eduardo Paes, poderá haver mudança na localizaçäo do Centro de Midia IBC/MPC (International Broadcast Centre/Main Press Centre), incluindo a própria Vila de Midia, para a Zona Portuária, atendendo à proposta 
defendida pelo IAB-RJ, que reproduziria o modelo adotado nas Olimpiadas de Barcelona11. Isso demonstra que inexiste, de fato, qualquer relação entre a localização da Vila de Mídia e a proposta de remoção, na medida em que se insiste com essa última proposta, sem que haja, no entanto, qualquer definição quanto à localização daquela instalação.

No caso em que seja confirmada a construção da Vila de Mídia junto ao Morro do Outeiro, deve-se destacar, ainda, que este é um monumento paisagístico do município, sujeito a proteção ambiental, segundo o Plano Diretor de 1992. É um morro todo florestado, não edificável. Cabe advertir que a construção de um empreendimento desse porte na fralda desse morro poderá provocar graves problemas ambientais.

\section{Existência de dificuldades técnicas para a execução das obras de urbanização na comunidade}

Esse argumento foi apresentado pelo Secretário Jorge Bittar na reunião do dia 3/3/2010. Se considerarmos o volume de intervençöes previsto para a região do Autódromo e do Riocentro, que abrigarão o Parque Olimpico, a Vila de Mídia e a Vila Olimpica, com a conseqüente necessidade de execução de investimentos vultosos na infraestrutura de saneamento ambiental, concluiremos que a discussão sobre a existência ou não de viabilidade técnica para a execução desse tipo de obras seria pertinente para a implantação de todo esse complexo, e não, especificamente, + para as obras de urbanizaçäo da comunidade. Bastaria mencionar que a Vila de Mídia e a Vila Olímpica serão transformadas, após a realização das competições em cerca de 12.000 unidades habitacionais de 2, 3 e 4 quartos, com a previsão de população permanente muito superior aquela existente na Comunidade da Vila Autódromo.

Mas caberia destacar, ainda, que ao contrário das recomendações constantes no PLUA/CELU para a remoção da comunidade ou das supostas restrições apontadas pelo Secretário, o documento de responsabilidade do Governo Federal aponta alternativa bastante diversa, ao expressar o compromisso com a permanência da comunidade, proposta destacada em um dos itens do referido documento, conforme transcrito a seguir:

\section{NOVA ZONA DE USO MISTO NA BARRA}

A implantação de uma zona de uso misto numa área da Barra da Tijuca hoje subutilizada, vizinha à Vila Olímpica, dentro do atual Autódromo de Jacarepaguá, ficara como legado urbano caso os jogos sejam realizados no Rio. Os dois prédios a serem construidos para abrigar o Centro Principal de Imprensa - MPC - e o Centro

\footnotetext{
11 "Rio 2016: Urbanista sugere que vilas olímpica e de imprensa fiquem na Zona Portuária" - O Globo on-line $-5 / 10 / 2009$.
} 
Internacional de Rádio e Televisão - IBC ... serão erguidos pela iniciativa privada, com cláusula de ocupação pelos compradores somente após os Jogos.

O impacto da construção será múltiplo. 0 uso misto vai provocar, além da reordenação do entorno degradado, movimentação econômica com atração de atividades comerciais e de serviços diversos. Uma mudança de perspectiva para as comunidades vizinhas, como a Vila Autódromo, onde vivem 350 familias de baixa renda em condições precárias de infraestrutura e de serviços. 0 município vai dar tratamento especial à situação de moradia daquela população. Como todo o entorno será urbanizado e ajardinado para os Jogos, os moradores também vão receber educação ambiental direcionada à preservação de seu bairro. 12

\section{Localização da comunidade (parte) no perímetro de segurança do Parque Olímpico}

Destaca-se, inicialmente, alguns trechos extraídos do Documento Oficial relacionados ao tema "Segurança"13:

- O Brasil não tem histórico relevante de atividade terrorista nacional ou internacional, e as autoridades brasileiras não identificaram no país quaisquer ameaças terroristas aos Jogos de 2016.

- A experiência do Brasil em garantir a segurança de grandes eventos na cidade, como a etapa brasileira do Revezamento da Tocha Olimpica de Atenas 2004, o famoso Carnaval carioca e as comemorações de Réveillon irão garantir a entrega de uma operação de segurança bem sucedida e amigável.

- Uma extensa rede de intervencões temporárias de sequrança será implantada para garantir a integridade de todas as instalações dos Jogos e prevenir o acesso não autorizado. Isso incluirá um perímetro de sequranca, o controle de acesso integrado e o gerenciamento de alarme, em conjunto com a vigilância técnica e o destacamento de pessoal de segurança e da policia.

A estrutura temporária de segurança resultante garantirá que o risco de acesso não autorizado nos Jogos seja muito baixo.

O Brasil possui um dos mais baixos perfis de risco para terrorismo no mundo, e jamais sofreu um ato de terrorismo internacional.

\footnotetext{
${ }^{12}$ Cadernos de Legado: "2. Legado Urbano e Ambiental” - Comitê de Gestão das Ações Governamentais Federais para a Candidatura Rio 2016

13 "Dossiê de Candidatura do Rio de Janeiro à Sede dos Jogos Olímpicos e Paraolímpicos de 2016" Conselho Executivo Rio 2016 / Volume III: "13. Segurança"
} 
Nunca houve uma ameaça terrorista a um grande evento no Rio de Janeiro, incluindo os Jogos Pan-americanos de 2007.

Ou seja, o Dossiê apresenta uma avaliação de que os riscos relacionados aos diversos tipos de incidentes que poderiam ameaçar a segurança dos Jogos são muito baixos e, conforme destacado em um dos trechos transcritos acima, as açōes de segurança serão estruturadas com base em uma rede de intervenções temporárias, na qual se inclui a delimitação de perimetros de segurança nos locais que irão sediar as competições e nos locais que irão hospedar todos os envolvidos com a realização dos Jogos.

A figura a seguir apresenta o plano geral das instalações dos Jogos na região da Barra da Tijuca, com a linha cheia na cor vermelha indicando o perímetro de segurança. Essa figura foi retirada da apresentação do Secretário Especial e corresponde exatamente àquela constante no Dossiê, com exceção do texto e das setas em vermelho.

\section{FIGURA 4}

\section{Requisitos de Segurança}

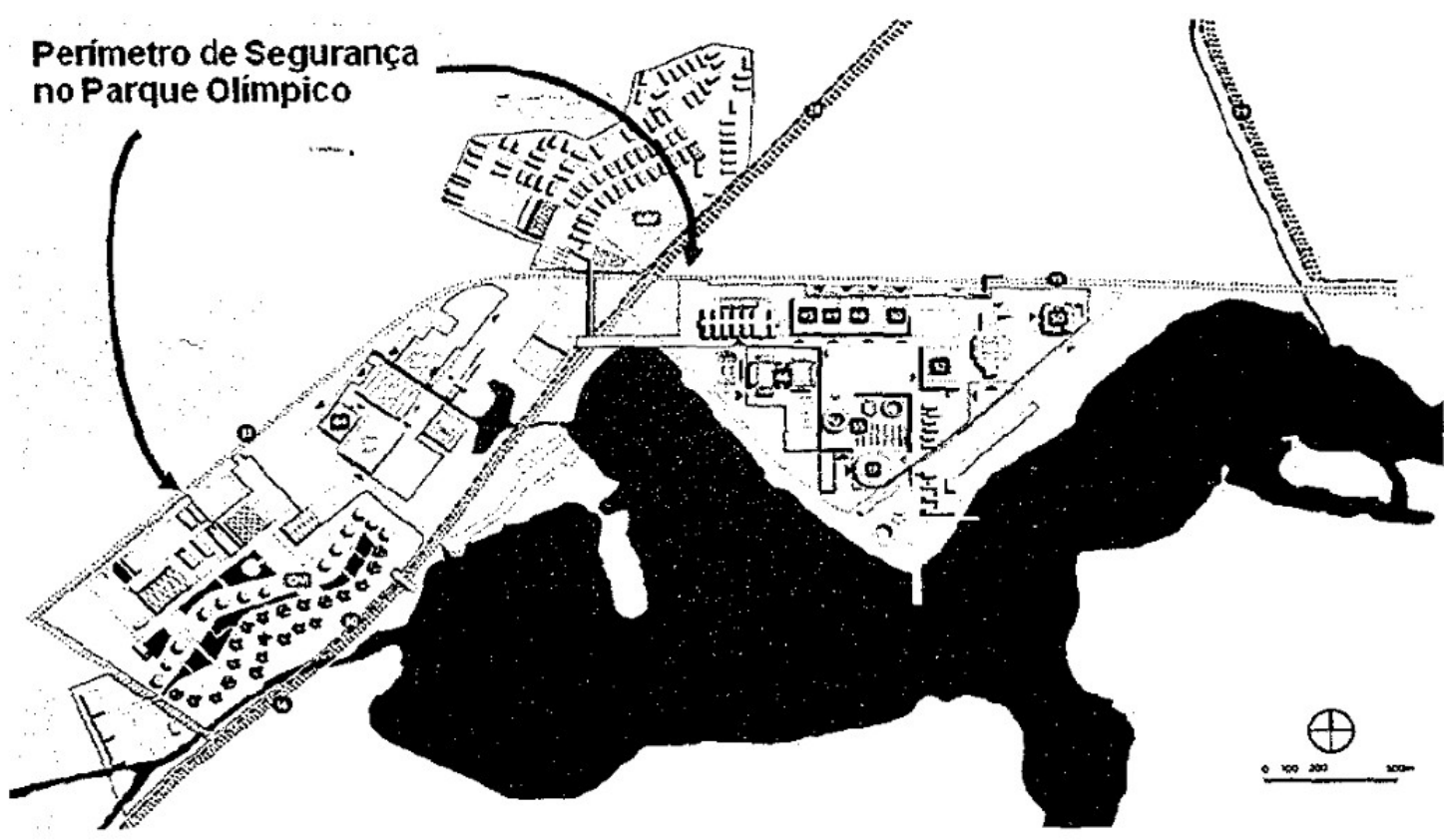

Fonte: "O Projeto Olimpico para o Autódromo" - Encontro com a Defensoria Pública e Lideranças da Comunidade - Secretaria Especial Copa 2014 / Rio 2016 - 30/3/2010

No detalhe, em escala maior, é possivel verificar que o perímetro de segurança contorna estritamente as áreas que abrigam as instalações destinadas às competições e à hospedagem. Identifica-se uma interferência minima sobre a área da Comunidade da Vila Autódromo, decorrente do traçado ortogonal adotado na face oeste do Autódromo, que faz limite com a comunidade e, também, do traçado da via de acesso para credenciados (A) que parte do Riocentro em direção ao Parque Olímpico, no sentido Oeste/Leste, e que encontra a via de 
acesso para credenciados $(B)$ que parte da Vila de Mídia, perpendicularmente, no sentido Norte/Sul.

Observa-se que apenas a via de acesso "A" corta a comunidade na área menos densa, formada por lotes que margeiam a lagoa, e como essas vias de acesso serão utilizadas apenas durante os Jogos, presume-se que sejam construídas com estruturas leves e desmontáveis, provavelmente como passarelas elevadas, considerando também a necessidade de evitar 0 possivel cruzamento com o fluxo de veiculos dentro e fora do Parque Olímpico, condições essas que poderiam minimizar ou eliminar a possibilidade de interferência sobre as edificações existentes.

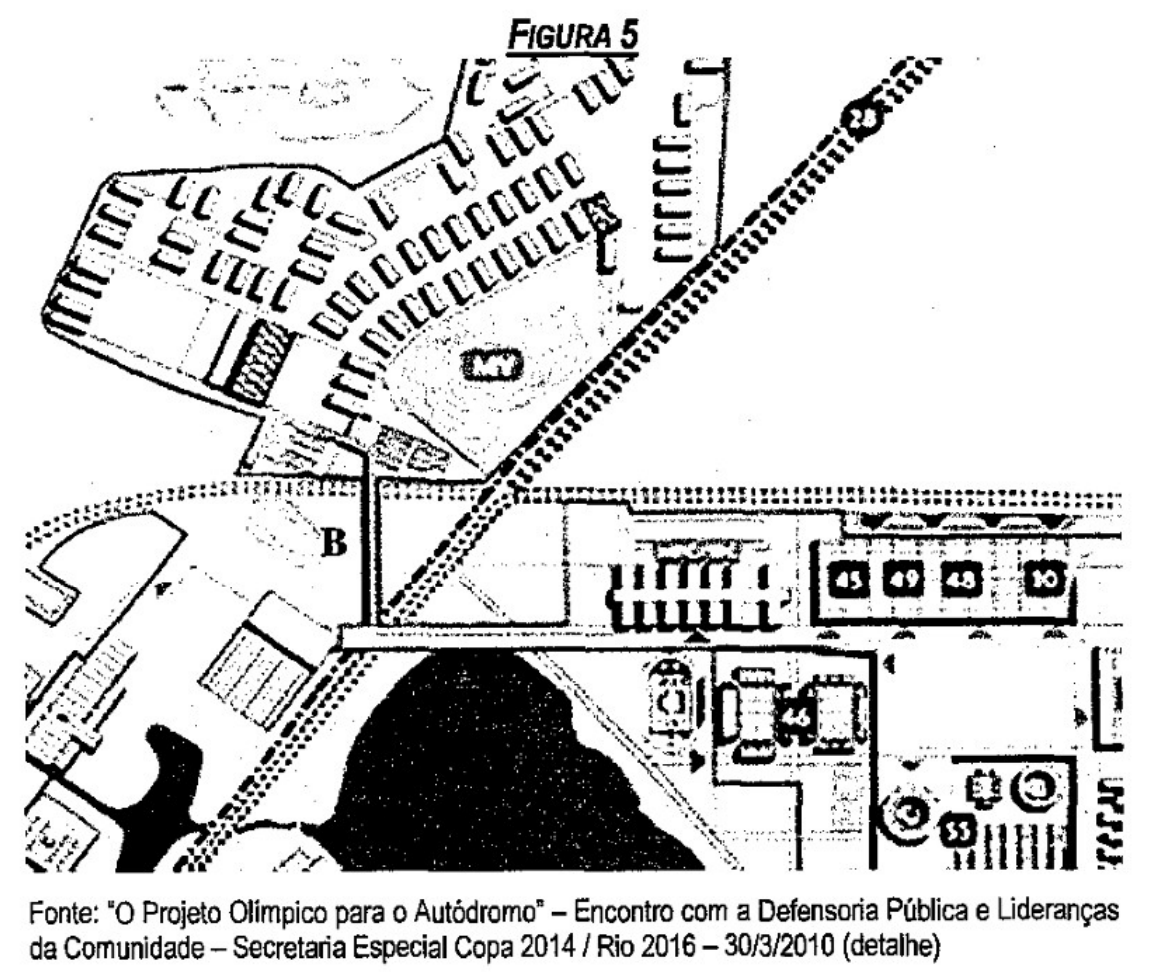

A figura com uma vista aérea da regiāo mostra a implantação da Vila de Mídia e a disposição das vias de acesso para credenciados com relação ao Parque Olímpico (a área da comunidade está representada como um "parque arborizado", o que será objeto de comentários no item referente a meio ambiente). 


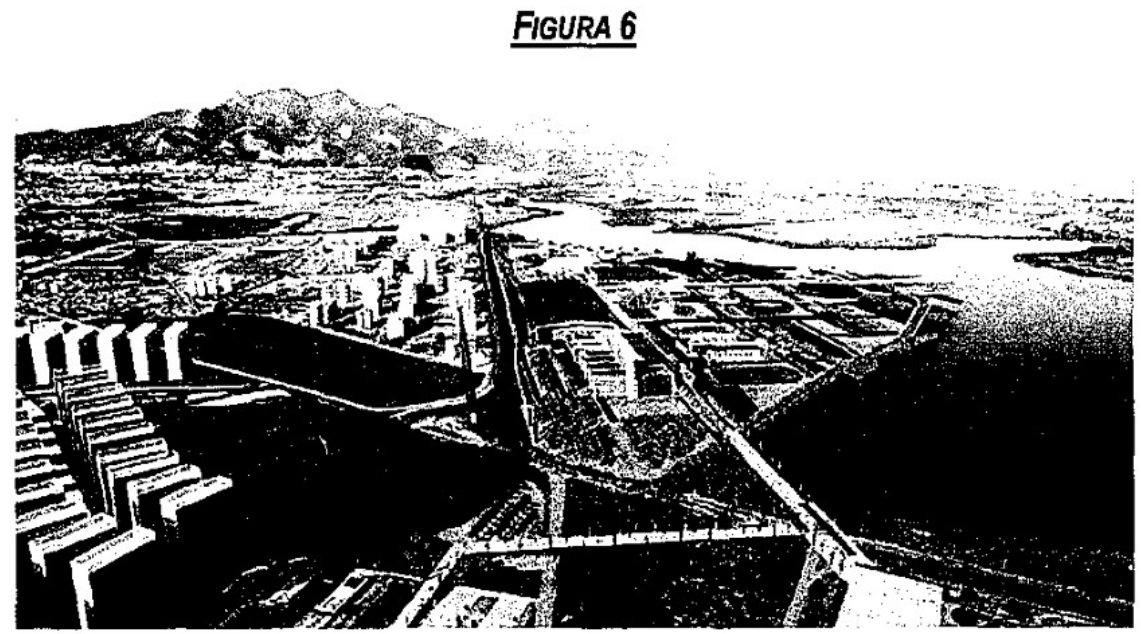

Fonte: "Dossiê de Candidatura do Rio de Janeiro à Sede dos Jogos Olimpicos e Paraolimpicos de 2016" Conselho Executivo Rio 2016 - Volume III: "14. Acomodaçöes"

Há uma contradição evidente entre, por um lado, os conceitos de segurança enunciados no Dossiê e a demarcação do perimetro de segurança, nos termos descritos acima, e, por outro lado, a proposta que foi apresentada pelo Secretário Especial, na reunião do dia 30/3/2010, como "condicionante de segurança" para a realização dos jogos: a necessidade de "criação de uma área livre junto ao perímetro do Autódromo" que, "coincidentemente", corresponde à área hoje ocupada pela Comunidade da Vila Autódromo.

Cabe destacar, em primeiro lugar, que o mapa demarcando o "Perímetro de Segurança no Parque Olimpico" (ver FiGURA 1), apresentado na referida reunião, não consta de quaisquer documentos elaborados para respaldar a candidatura do Rio de Janeiro junto ao $\mathrm{CO}$.

Em segundo lugar, pelo que se depreende do conceito de segurança enunciado no Documento Oficial e das demarcações ali apresentadas, o critério básico para a definição do "perímetro de segurança" é a delimitação das áreas que abrigam instalaçōes destinadas à realização das competições ou à hospedagem dos atletas e jornalistas, nas quais è necessário que seja adotado o controle do acesso, o que não se aplica a uma "área livre", sem qualquer destinação definida.

Em terceiro lugar, o "perímetro de segurança ampliado" que, em termos práticos, "unificaria' as três principais instalações (Parque Olímpico, Vila de Mídia e Riocentro), seria, além de desnecessário, absolutamente inviável, pois implicaria em estender o controle de acesso também para a Avenida Salvador Allende, tornando totalmente inoperante o sistema de circulação proposto para a regiāo (Sistema BRT, Avenida Embaixador Abelardo Bueno e Avenida Salvador Allende). 
A Figura 7 destaca os "perímetros de segurança" das diferentes instalações (em vermelho) e também indica as áreas que são ocupadas por núcleos habitacionais formados por prédios de apartamentos destinados a familias de classe média/alta, além de indicar a própria Comunidade da Vila Autódromo (em laranja).

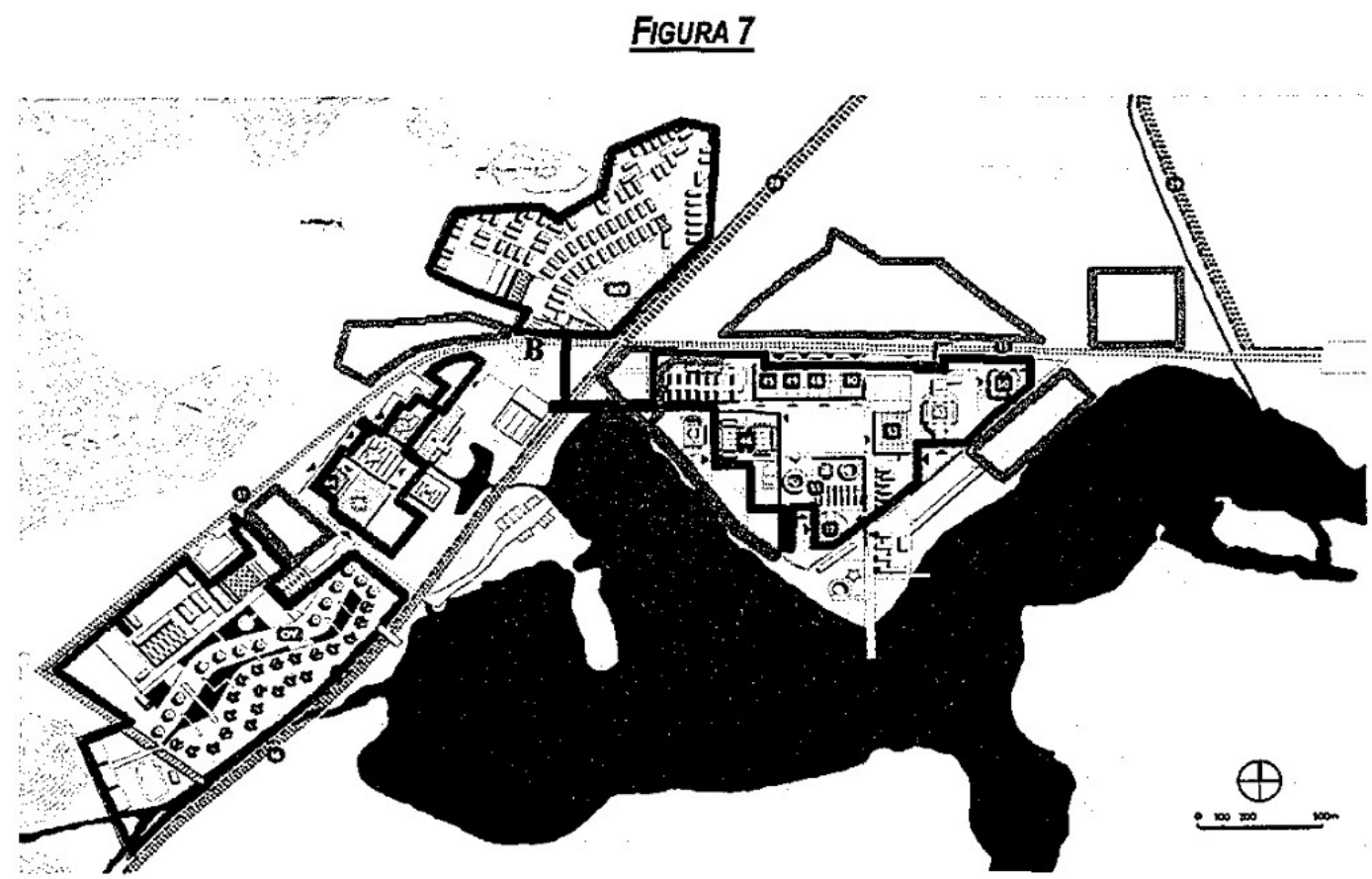

Fonte: "O Projeto Olimpico para o Autódromo" - Encontro com a Defensoria Pública e Lideranças da Comunidade - Secretaria Especial Copa 2014 / Rio 2016 - 30/3/2010 (marcações executadas sobre imagem original)

Como se pode verificar os perimetros de segurança envolvem áreas que estão isoladas entre si, intercaladas por outros terrenos e edificaçōes não relacionados às instalações dos Jogos Olimpicos.

Portanto, fica bastante claro que não há qualquer exigência de segurança associada à necessidade de instalações/áreas contínuas ou mesmo de instalações/áreas interligadas por vias segregadas, de caráter exclusivo (como as vias de acesso "A" e "B"). Mesmo a previsäo de que o IBC/MPC e a Vila de Mídia fiquem "dentro do mesmo perímetro de segurança, permitindo ligações a pé entre essas duas instalações e o Núcleo do Parque Olímpico do Rio, sem a necessidade de checagem de segurança" 14 é bastante questionável, considerando que os demais deslocamentos serão realizados mediante a utilização das vias de circulação da cidade e que os próprios atletas farão todos os seus deslocamentos entre a Vila Olimpica e os locais de competição dessa mesma forma.

\footnotetext{
14 "Dossiê de Candidatura do Rio de Janeiro à Sede dos Jogos Olímpicos e Paraolímpicos de 2016" Conselho Executivo Rio 2016 / Volume III: "17. Operações de Mídia"
} 
Por outro lado, como os terrenos que abrigarão as instalações previstas para essa região estão intercalados por diversos núcleos habitacionais e centros locais de comércio e serviços, é necessário que se justifique porque somente a Comunidade da Vila Autódromo representa um "incômodo" para a realização dos Jogos Olimpicos e porque sua remoção está pretensamente incluida entre os "condicionantes de segurança".

A hipótese de generalizar a aplicação desse mesmo "conceito de segurança" em outras áreas seria suficiente para demonstrar o absurdo da proposta: as competições dos jogos Olímpicos serão realizadas em equipamentos esportivos inseridos no espaço urbano, devendo, portanto, se adaptar à dinâmica e às atividades cotidianas da cidade e não o seu contrário, a cidade se adaptar a uma atividade cuja duração é de menos de três semanas. Isso implica, também, na necessidade de respeitar a população da cidade que sedia os Jogos, o que em uma sociedade democrática deveria ocorrer sem discriminação de classes sociais.

No entanto, fica evidente que a proposta de adoção de um perimetro de segurança "ampliado" é apenas uma "roupagem nova" para a estratégia de remover, a qualquer custo, a Comunidade da Vila Autódromo, o que se tornou, já há alguns anos, uma obsessão de seguidas administrações municipais. Há, na verdade, apenas duas justificativas plausiveis para a atual proposta da prefeitura que, na verdade, parecem ser complementares:

- O preconceito arraigado nas elites de nossa sociedade, de que a existência de uma comunidade pobre nas imediações do local de realização dos Jogos representaria uma "ameaça à segurança dos Jogos", avaliação que, obviamente não é estendida aos prédios de classe média existentes no entorno do Autódromo e de outras instalações que também sediarão as competições, localizadas em outros bairros. Segundo essa justificativa, a Comunidade da Vila Autódromo passa a ser equiparada aos mais temidos grupos terroristas, que tem assombrado os organizadores de grandes eventos internacionais ${ }^{15}$.

- A outra justificativa, mais prosaica, são os interesses do capital imobiliário que está associado a viabilização da infraestrutura olímpica - em especial, mas não somente, a construção da Vila de Mídia e da Vila Olímpica. O capital imobiliário necessita criar "áreas exclusivas" como mecanismo para aumentar seus lucros e, sendo assim, historicamente, adota a estratégia de expulsar as comunidades pobres dos arredores de seus empreendimentos, por entender que a existência dessas comunidades contribui para diminuir suas expectativas de

\footnotetext{
${ }^{15}$ Caberia acrescentar, como argumento que refuta a hipótese absurda de que a presença da Comunidade da Vila Autódromo representaria uma "ameaça" á Rio 2016, a própria realização dos Jogos Panamericanos, cujas exigências de segurança são equiparadas aquelas dos Jogos Olímpicos e que ocorreram sem o registro de qualquer incidente.
} 
lucros. Nesse caso, a Comunidade da Vila Autódromo está ameaçada de ser atingida pelo mesmo processo de expulsão que tem vitimado diversas outras comunidades, com uma diferença quanto ao pretexto agora utilizado: a realização dos Jogos Olímpicos.

\section{Localização da comunidade (parte) na Faixa Marginal de Proteção}

As ações relacionadas aos objetivos de proteção ambiental, desenvolvidas no tema "Meio Ambiente e Meteorologia", estão especificadas no Plano de Gestão de Sustentabilidade Rio 2016 (PGS), estruturado com base em três "pilares":

- Planeta - significa o compromisso ambiental geral dos Jogos através da promoção de ações locais, mas com uma visão global para a sustentabilidade;

- Pessoas - refere à necessidade de importantes ganhos sociais para toda a população do Rio; e

- Prosperidade - é o símbolo de Jogos bem administrados e geridos de maneira transparente, contribuindo para o crescimento econômico da cidade. ${ }^{16}$

"Com foco na melhoria do meio ambiente (Planeta), na qualidade de vida (Pessoas) e na economia (Prosperidade), o PGS reflete objetivos especificos associados às prioridades da cidade agrupados em quatro temas", a saber: "Jogos pela conservação da água", "Jogos pela energia renovável", "Jogos neutros em carbono" e "Gestão do lixo e responsabilidade social"17.

As açōes descritas, relacionadas a esses diferentes temas, são de caráter abrangente, constituindo, em muitos casos, diretrizes gerais que deverăo ser observadas no projeto e construção das instalaçōes esportivas ou durante a realização dos jogos. Alguns exemplos: a construção das instalações deverá seguir as normas internacionais de economia de água; está prevista a implantação de unidades independentes de tratamento de esgotos no Centro Olímpico de Treinamento e Vila Olimpica e Paraolímpica, localizados na Barra, como também em outras instalaçōes; há previsão de que $100 \%$ da frota de ônibus públicos circulará com alto uso percentual de combustivel limpo (biodiesel, etanol), etc.

Não há, portanto, no detalhamento das ações que constituem o PGS, qualquer menção à Faixa Marginal de Proteção ou qualquer proposta de remoção de comunidades em função de "questões ambientais" ou como parte de um projeto de "despoluição" da Lagoa de Jacarepaguá. Nos mapas e cartogramas apresentados não consta também a representação gráfica da FMP para o sistema lagunar e para os demais corpos hídricos da região.

\footnotetext{
16 "Dossiê de Candidatura do Rio de Janeiro à Sede dos Jogos Olímpicos e Paraolímpicos de 2016" Conselho Executivo Rio 2016 / Volume I: “6. Meio Ambiente e Meteorologia"

${ }^{17}$ ibidem
} 
O Cartograma reproduzido a seguir apresenta o "Plano Local" para a regiäo da Barra da Tijuca, registrando as intervenções previstas, relacionadas a diferentes áreas.

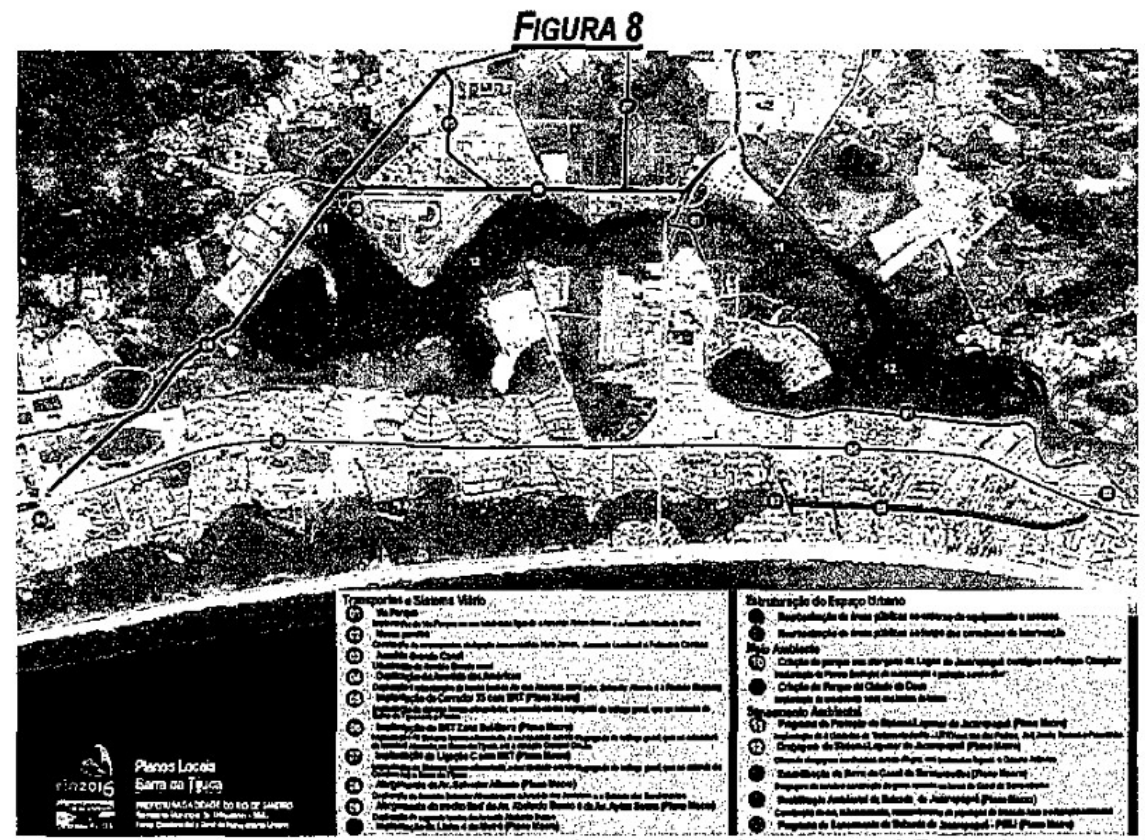

Fonte: "Plano de Legado Urbano e Ambiental - Olimpiadas Rio 2016" - Comitế Especial de Legado Urbano - CELU - Volume III/Cartogramas.

No detalhe do Cartograma, podemos identificar que a área ocupada pela Comunidade da Vila Autódromo é representada por um vazio que segundo a legenda - item 10 corresponderia a um "Parque Ecológico de recuperação e proteção [d]a mata ciliar".

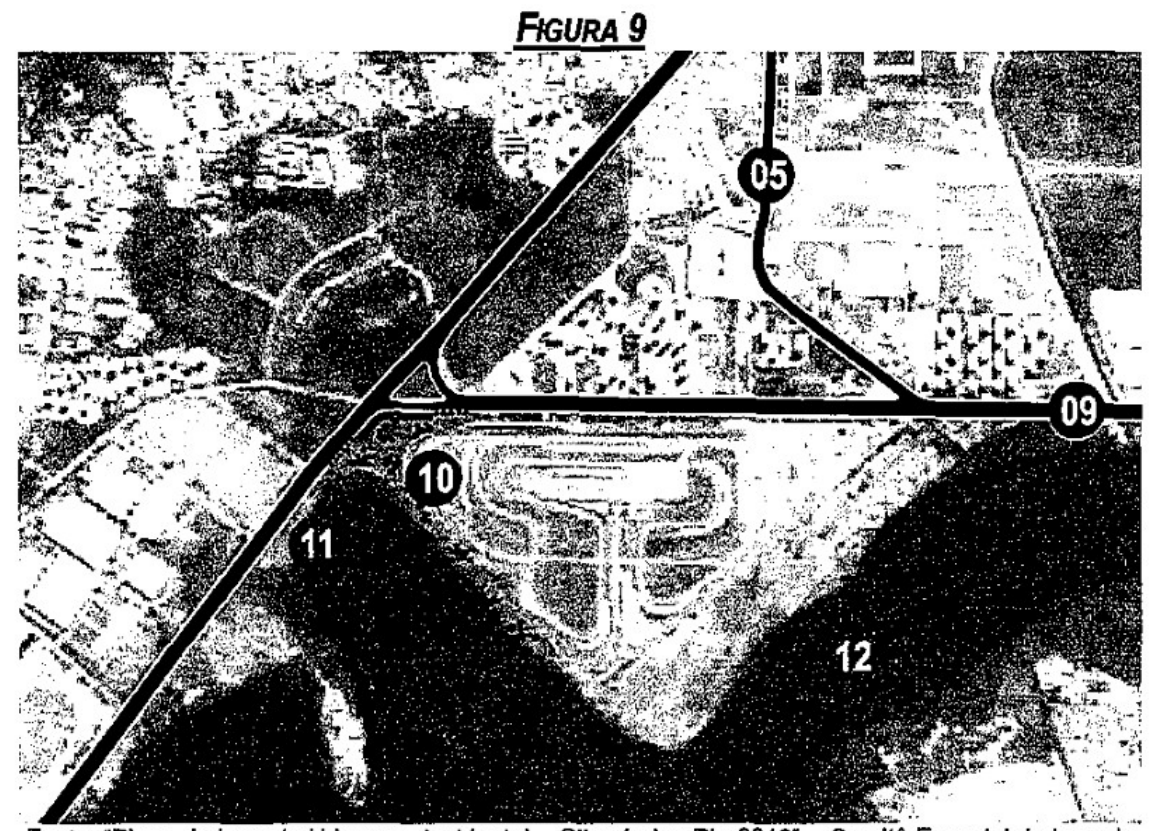

Fonte: "Plano de Legado Urbano e Ambiental - Olimpiadas Rio 2016" - Comitê Especial de Legado Uibano - CELU - Volume III/Cartogramas. (detalhe)

Também nesse caso, encontramos no PLUA/CELU proposta que não está incluída no Documento Oficial da candidatura do Rio de Janeiro para sediar os Jogos Olímpicos de 2016. 
A maior parte das propostas relacionadas aos temas "Meio Ambiente" e "Saneamento Ambiental" aplicadas à região da Barra da Tijuca estão descritas no "Plano Macro" de uma forma bastante genérica. Assim, o projeto de despoluição da baixada de Jacarepaguá envolve "ações de drenagem, esgotamento sanitário e manejo de residuos sólidos e o programa de reabilitação ambiental, na mesma região, envolve "ações de macrodrenagem, reflorestamento, reassentamento de famílias que moram em áreas de risco e educação ambiental"18.

Essas propostas gerais foram "interpretadas" para o "Plano Local" da Barra da Tijuca, onde encontramos a seguinte proposta relacionada ao tema "Meio Ambiente":

\begin{tabular}{|c|c|c|}
\hline Código & Açä0 & Objetivos/Descricăo \\
\hline BR.3 & MEIO AMBIENTE & \\
\hline BR.3.1 & $\begin{array}{l}\text { Criaçāo de Parque } \\
\text { margens da Lagoa } \\
\text { Jacarepaguá, contiguo ao } \\
\text { Parque Olimpico }\end{array}$ & $\begin{array}{l}\text { Implantação de Parque Ecológico de recuperaçăo e proteçăo à mata ciliar da faixa Marginal de } \\
\text { Proteçāo da Lagoa de Jacarepaguá }\end{array}$ \\
\hline
\end{tabular}

Esse, então, é o parque que podemos "apreciar" na simulação apresentada na Figura 6, com certeza considerado pelos autores da proposta, inspirados pela tese do "dano estético e ambiental" já defendida pela Procuradoria Geral do Municipio, como "uma imagem mais apropriada" para uma área que fica no entorno das instalações dos Jogos do que a imagem de uma comunidade de baixa renda.

Ora, o "Plano Local", conforme demonstrado no cartograma, abrange uma vasta região que inclui a Lagoa de Jacarepaguá e a Lagoa da Tijuca e todo o seu entorno, região essa onde é possivel identificar a existência de extensas áreas ocupadas por diferentes tipos de construçöes, além de diferentes usos e atividades.

Curiosamente, a única ação proposta, aplicável a uma área específica e que atinge uma comunidade especifica é a de criação do citado "Parque Ecológico", viabilizando, assim, "a recuperação e proteção à mata ciliar" no único trecho da lagoa onde essa ação foi considerada tão importante, que foi utilizada como justificativa para propor a remoção de uma comunidade enraizada nesse local há décadas, e em detrimento da especificação de quaisquer outras ações para toda a região abrangida pelo referido plano ${ }^{19}$.

É bastante evidente que essa proposta, tal como formulada, carece de qualquer fundamento técnico. Entende-se que a formulação de um programa de proteção e recuperação do Sistema Lagunar de Jacarepaguá, iniciativa louvável, deveria, necessariamente vir

\footnotetext{
18 "Plano de Legado Urbano e Ambiental - Olimpíadas Rio 2016" - Comitê Especial de Legado Urbano CELU - Volume I: "4. Plano Macro".

${ }_{19}$ A outra proposta relacionada ao tema "Meio Ambiente", a criação do Parque da Cidade de Deus, que consistira na "implantação de um cinturāo verde nos limites do bairro", sequer é representada graficamente no cartograma.
} 
acompanhado de um diagnóstico detalhado, que apresentasse um estudo da evolução da ocupação dessa região e identificasse quais são os usos e atividades de maior impacto ambiental, além de apresentar uma estimativa quantitativa e qualitativa de qual a contribuição de cada um desses usos e atividades para os atuais tipos e niveis de poluição existentes. Além disso, seria necessário identificar a quem, de fato, cabe a responsabilidade pelos poluentes lançados na lagoa, pois no caso, por exemplo, de comunidades não atendidas por rede de esgoto, essa responsabilidade cabe ao poder público. Ou seja, há necessidade de identificar os usos e atividades poluidoras, dimensionar qual o grau efetivo de participação destes e, também, identificar as responsabilidades.

Como forma de permitir uma avaliação do alcance e consistência de um projeto de despoluição, seria necessário, ainda, que as ações propostas estivessem correlacionadas a metas quantitativas claras que demonstrassem quais seriam as melhorias reais alcançadas num determinado periodo e quais os custos envolvidos (econômicos, sociais, ambientais, etc).

Uma proposta de remover uma comunidade em nome de "questōes ambientais", sem levar em consideração esses aspectos, só pode ser entendida como a utilização da questäo ambiental como pretexto para atingir outro objetivo que, embora não esteja claramente enunciado, é amplamente conhecido: a liberação de áreas valorizadas, de forma a atender aos interesses do capital imobiliário.

Outro tipo de análise sobre essa questão pode ser realizado a partir das fotos de satélite apresentadas na Figura 10 e na Figura 11, que mostram a região que abrange as ilhas da Gigóia e dos Pescadores e a Comunidade da Vila Autódromo, respectivamente, sendo que a primeira está situada na Lagoa da Tijuca, próxima à Estrada da Barra da Tijuca e ao Itanhangá Golf Club.

Pode-se observar, no caso das ilhas, uma ocupação muito densa, com construções muito próximas ou localizadas praticamente nas margens da lagoa, identificando-se, inclusive, a existência de diversos pieres. 


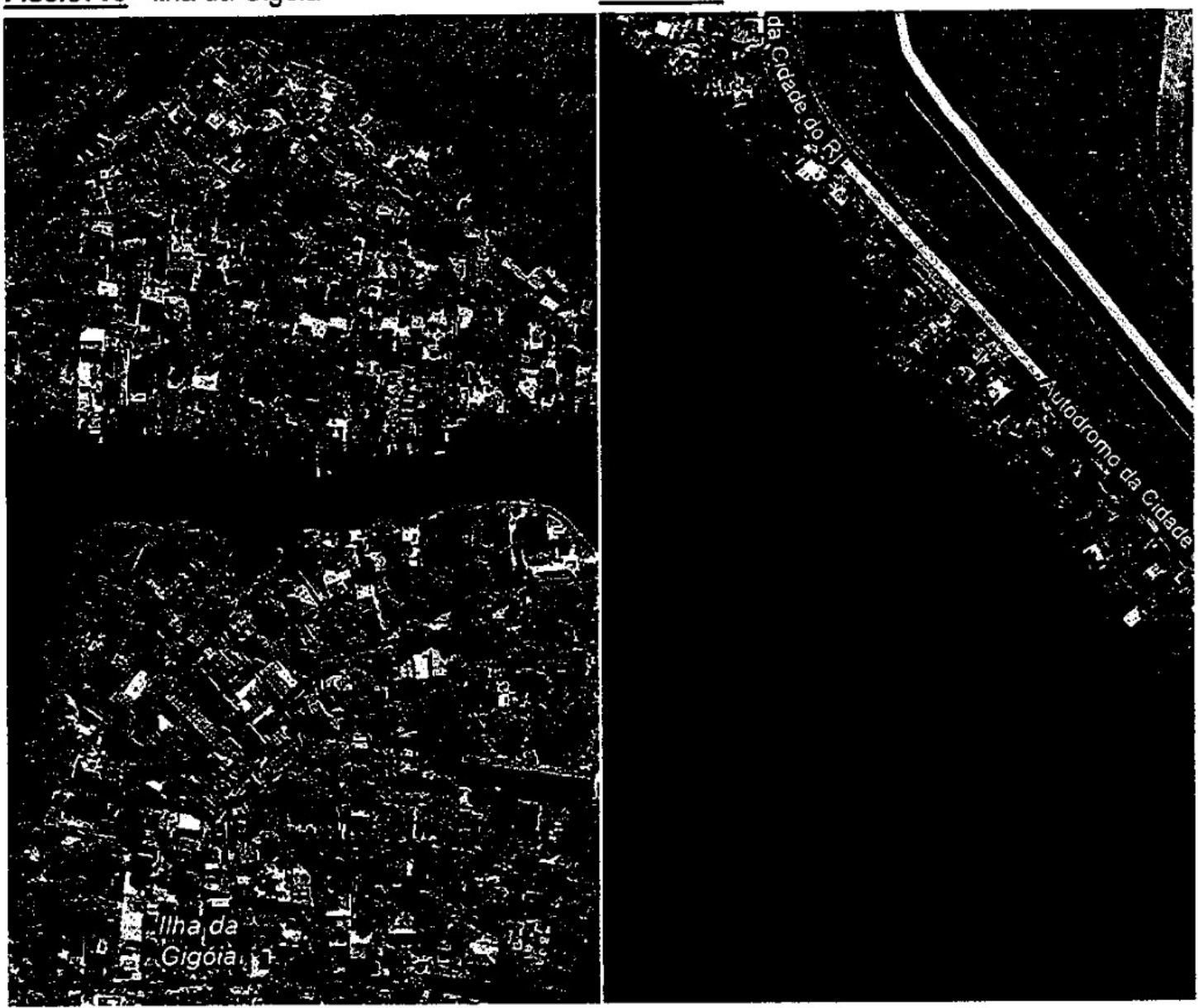

Fonte: Google maps

A Comunidade da Vila Autódromo, por sua vez, apresenta áreas com caracteristicas distintas: uma formada por um núcleo mais denso, que ocupa a faixa de terra delimitada pela Lagoa de Jacarepaguá, Avenida Salvador Allende, Avenida Embaixador Abelardo Bueno e pela extensão desta, paralela ao muro do autódromo; e outra, menos densa, que ocupa a faixa de terra entre o muro do autódromo e a lagoa, e que estaria inserida na FMP, motivo apresentado como justificativa para a remoção pretendida. Cabe ressaltar que a Comunidade da Vila Autódromo existe há mais de quarenta anos, tendo se originado de um núcleo pioneiro de pescadores que ocupavam as margens da Lagoa de Jacarepagua ${ }^{20}$.

20 “Quando o Rio de Janeiro ainda era Estado da Guanabara, ... quando ninguém queria morar pelas bandas da Barra e Jacarepaguá, porque era área rural, local deserto e inóspito, cheio de mosquitos, sem iluminação, água encanada e transporte, só pescadores ali habitavam por necessidade $e$ questão de sobrevivência.

Desde 1962 aqueles pescadores ocupavam as margens da Lagoa de Jacarepaguá, que eles denominavam Lagoinha, parte da qual foi aterrada em 1975 para as construções do Autódromo de Jacarepaguá e de um conjunto residencial para a Aeronáutica. 
A semelhança entre a área ocupada pelas ithas da Gigóia e dos Pescadores e a área ocupada pela Vila Autódromo está no fato de ambas serem ocupações antigas, inseridas parcialmente na FMP. A diferença está em que, enquanto em uma predomina uma população de renda média/alta que não está incluída no plano de "despoluição" da lagoa, a outra abriga, predominantemente, famílias de baixa renda e está ameaçada de remoção pelos alegados motivos ambientais.

Um levantamento abrangente em toda a área no entorno das lagoas revelaria a existência de inúmeras outras ocupações em situações semelhantes às duas citadas como exemplos. No entanto, não se cogita, nem seria razoável, uma proposta de desocupação de todas as áreas que foram incorporadas ao tecido urbano, na regiäo de Jacarepaguá ou em outras regiões da cidade, com o objetivo de que essas áreas recuperassem sua condição de "bem natural intocado". Se fosse esse o caso, seria necessário não só a transferência de boa parte da cidade para outro sítio, como também encontrar outro lugar para a realização das competições olimpicas, já que o Riocentro e o Autódromo foram construídos sobre aterro das lagoas existentes ${ }^{21}$.

Tanto estas construções quanto o aterro das pequenas lagoas existentes no local empurraram aqueles pescadores para uma estreita faixa de terra entre os muros do Autódromo e a sinuosa margem da lagoa. A atual comunidade Vila Autódromo, nos seus quarenta anos de existência, originou-se daqueles pioneiros pescadores e suas familias ...

Com as grandes obras dos anos 70 , muitos núcleos de pescadores foram deslocados e migraram para a região, formaram novas comunidades (Camorim, Rio das Pedras, Muzema) e agregaram-se as já existentes, como a Vila Autódromo, e organizaram-se em Associações de Pescadores e Moradores.

As construções do Rio Centro e do Autódromo trouxeram ainda muitos trabalhadores, que por näo terem moradia ou morarem muito longe, acabaram transferindo-se para a região com as respectivas familias, quando não formaram simplesmente novas familias, integrando-se desta forma com os habitantes originais.

Com o final da última grande construção daquela época, a do Metrô, nova leva de operários migrou para a região em busca das oportunidades de trabalho propiciadas pelas construções e pelos novos condomínios da Barra e da pesca farta na Lagoa.

Aquela mescla de pessoas de diferentes origens formou a comunidade Vila Autódromo, que conseguiu se organizar juridicamente em 1987, ao fundar a Associaçäo dos Moradores e Pescadores da Vila Autódromo - AMPAVA, com estatuto, sede própria, CGC, e demais formalidades legais. A partir daí a comunidade conquistou luz elétrica, água encanada, fossas sépticas e sumidouros em todas as residências, telefones, ruas traçadas, documentação formal e registro na Marinha e no Ibama para os remanescentes sessenta pescadores profissionais, duas igrejas evangélicas e um núcleo da Pastoral das Favelas da Igreja Católica. Tudo construído e organizado pelos próprios moradores, sem qualquer apoio governamental, a despeito do IPTU pago por boa parte dos moradores com base na mesma planta de valores aplicada na Barra da Tijuca."

["Histórico da Comunidade Vila Autódromo". Por Inalva Mendes Brito; 15/04/2006; disponível em http://www.midiaindependente.org/pt/blue/2006/04/351095.shtml]

21 “Em 1906 criou-se a $1^{a}$ Colônia de Pesca do Brasil, exatamente em Jacarepaguá que se confundia (como até hoje) com a Barra e o Camorim. $O$ acesso às lagoas e as praias era conhecido por Caminho das Pedrinhas (hoje Ladeira São Gonçalo do Amarante) e o Caminho do Pescador (hoje Av. Salvador Allende). 
Isso demonstra que estamos diante de um problema complexo, que diz respeito aos processos que determinaram a forma particular como a cidade se desenvolveu, avançando muitas vezes sobre áreas com características impróprias à ocupação, com a consequente produção de impactos negativos sobre os ecossistemas existentes. Não há dúvidas, também, quanto à necessidade de que as diretrizes de uso e ocupação do solo estejam integradas às diretrizes de preservação e recuperação do meio ambiente, de forma a impedir o avanço desse processo de deterioração e a viabilizar a recuperação mesmo que parcial de ecossistemas degradados, esperando, assim, melhorar a qualidade de vida da população.

Essas observações parecem representar uma espécie de consenso que, entretanto, começa a se desmanchar quando introduzimos, como novo elemento dessa reflexão, as relações sociais concretas que determinam a produção de um espaço urbano que é marcado por profundas desigualdades sociais.

É necessário enfatizar que os diferentes grupos e classes sociais não são afetados pelos impactos ambientais da mesma forma e no mesmo grau.

As comunidades de pescadores, por exemplo, que viram minguar a atividade de pesca em decorrência da mortalidade ou contaminação dos peixes, decorrente da poluição provocada pela ocupação predatória dessa região, enfrentam graves dificuldades para viabilizar o sustento de suas famílias, não sendo uma questão corriqueira, nem a reversão da poluição para níveis que permitam a retomada da atividade pesqueira, nem o deslocamento desses profissionais para outras atividades econômicas que possam garantir a sua sobrevivência.

Outro exemplo que pode ser citado é o aumento do potencial construtivo de determinadas áreas, por pressão do mercado imobiliário, sem que a área seja dotada de infraestrutura que possa suportar o aumento da densidade populacional, o que produz graves impactos ambientais que somente virão a ser revertidos mediante a realização de significativos investimentos públicos que, em última instância, beneficia os próprios infratores: os empreendedores imobiliários que se utilizam desse mecanismo. Sem muito esforço, pode-se perceber que essa foi a forma como se deu a forte expansão verificada na região da Barra da Tijuca nos últimos anos.

Conforme foi demonstrado, o PLUA/CELU não contém uma proposta consistente de recuperação ambiental para essa região. Aliás, a abordagem da questão ambiental por ele adotada ignora todos os processos mencionados, carecendo, portanto, de base técnico-científica

Por esta época, o complexo da Lagoa de Jacarepaguá e suas lagoinhas (aterradas dando lugar ao Rio Centro e ao Autódromo) constituía um berçário natural, alimentado pelos rios, córregos e o mar." [ibidem] 
e de qualquer compromisso ético-social. Diante do exposto, pode-se concluir que a inclusäo da proposta de remoção da Comunidade da Vila Autódromo nesse documento somente se justifica por um motivo que já foi destacado: o profundo comprometimento de suas propostas com os interesses do capital imobiliário.

20. Diante do exposto, apresenta-se as seguintes considerações acerca das alegações apresentadas pela prefeitura que justificariam a proposta de remoção da Comunidade da Vila Autódromo, sejam aquelas veiculados pela imprensa, sejam aquelas apresentadas nas reuniões realizadas entre a prefeitura e representantes da comunidade:

- A remoção da Comunidade da Vila Autódromo ou qualquer ação que afete essa comunidade não consta do Documento Oficial da candidatura apresentado ao $\mathrm{COI}$, não havendo assim como alegar qualquer vinculação com esse documento ou, ainda, qualquer "determinação do COl" como justificativa para essa proposta.

- Entre as alegações apresentadas para justificar a proposta de remoção da Comunidade da Vila Autódromo verificou-se que ou elas não constam em qualquer dos documentos (construção do Centro de Mídia; dificuldades para execução das obras de urbanização; e atendimento de condicionantes de segurança dos Jogos) ou constam apenas do Plano de Legado Urbano e Ambiental - PLUA (execução de obras de infraestrutura viária e atendimento de condicionantes ambientais).

- Constata-se, portanto, que a proposta de remoção da Comunidade da Vila Autódromo, como tal, está expressa apenas no Plano de Legado Urbano e Ambiental (PLUA), documento cuja elaboração é de responsabilidade exclusiva da prefeitura e que apresenta contradições flagrantes com o Documento Oficial da candidatura do Rio de Janeiro apresentado ao $\mathrm{COI}$, ainda, com um terceiro documento de responsabilidade do Governo Federal.

- O Plano de Legado Urbano e Ambiental é um documento construído com base em premissas falsas de planejamento de longo prazo, carecendo, portanto de legitimidade 22 , e cujas propostas,

\footnotetext{
${ }^{22} \mathrm{O}$ texto de apresentação do "Plano de Legado Urbano e Ambiental" afirma que "a Prefeitura do Rio, por meio da Secretaria de Urbanismo, optou por ancorar este Plano no processo de planejamento da cidade, expresso no seu Plano Diretor Decenal em vigor, e na política de ordenamento territorial prevista em sua revisão, atualmente em discussão na Câmara dos Vereadores".

Ocorre que por omissão da gestão passada e da atual, a cidade do Rio de Janeiro ainda não tem um Plano Diretor revisado nos termos estabelecidos pelo Estatuto da Cidade. Pelo contrário, o atual processo de revisão do Plano Diretor é manifestamente ilegal, tanto por não atender aos preceitos de participação da sociedade, como por não atender ao conteúdo mínimo que tem como objetivo promover a função da propriedade e combater a especulação imobiliária.

O processo de revisão do Plano diretor se arrasta já há quase dez anos, tendo sido objeto de críticas contundentes por parte de diferentes entidades da sociedade civil e do Ministério Público Estadual. Mais recentemente, em janeiro desse ano, o projeto de lei em tramitação e o processo de revisão em si foram alvo de análise minuciosa por parte do Instituto de Pesquisa e Planejamento Urbano e Regional -
} 
ou são excessivamente genéricas, ou estão eivadas de preconceitos contra as comunidades pobres, a exemplo da proposta de remoção da Comunidade da Vila Autódromo, que não possui relação com a realidade nem qualquer embasamento técnico-científico.

- Os termos em que foi formulada a proposta de remoção leva a concluir que a prefeitura tenta utilizar-se da realização dos Jogos Olímpicos como pretexto para justificar a remoção da Comunidade da Vila Autódromo e de outras comunidades localizadas em áreas valorizadas, que são de interesse da especulação imobiliária.

- No que se refere à motivação original das reuniōes entre a prefeitura e a comunidade, deve prevalecer o direito conquistado pela comunidade, assegurado em inúmeros instrumentos juridicos, de permanecer na área e exigir que essa permanência seja acompanhada, necessariamente, da realização de investimentos que assegurem uma melhor qualidade de vida para os moradores.

\section{As "vantagens" da proposta de remoção da prefeitura}

Historicamente, as remoções ficaram marcadas na memória da população do Rio de Janeiro como ações que consistiram em arrancar comunidades inteiras das áreas por elas ocupadas há várias gerações, expulsando seus moradores para conjuntos habitacionais de baixa qualidade localizados em áreas remotas, e destruindo os laços sociais, culturais, econômicos e afetivos existentes nessas comunidades.

Em todas as remoções realizadas, sempre por meio de ações autoritárias e truculentas, o poder público agiu e age como um braço do poder econômico, promovendo a "limpeza social" de áreas valorizadas, que são objeto de cobiça do capital imobiliário.

Desde a década de 1960, as comunidades de favelas do Rio de Janeiro organizaram-se para resistir contra essa violência e para afirmar o direito à habitação e o direito à cidade, luta essa que foi vitoriosa, tendo como resultado o reconhecimento do direito de essas comunidades permanecerem nos seus locais de origem, além de criar a obrigação de que o poder público implementasse programas de regularização fundiária e urbanização, como forma a proporcionar melhores condições de vida para seus moradores.

Assim, o termo "remoção" foi banido do discurso e das ações do poder público na área da política urbana até meados da década de 1990, a partir de quando alguns governos conservadores, entre os quais o da cidade do Rio de janeiro, vem tentando retomar essa prática nefasta, de triste memória para as comunidades pobres da cidade.

IPPUR/UFRJ, expressa no "Relatório de avaliação técnica das propostas de revisão do Plano Diretor Decenal da Cidade do Rio de Janeiro", que resultou na apresentação de severas críticas. 
No caso da atual proposta que ameaça a Comunidade da Vila Autódromo, a remoção vem travestida de uma "nova roupagem", que a diferenciaria da proposta de remoção dos "tempos do Lacerda". Trata-se, agora, segundo a descrição do Secretário Municipal de Habitação, Jorge Bittar, de uma "remoção de face humana", cujo principal objetivo seria, na verdade, proporcionar condições de vida dignas para as famílias.

Por essa proposta, as comunidades contariam com projetos elaborados por profissionais "experientes" e "bem intencionados"; os moradores poderiam "interferir" no projeto; as áreas para onde as famílias seriam removidas "não seriam tão remotas quanto antes"; e, ainda, seria garantida a qualidade das novas residências, reproduzindo, inclusive, as condições daquelas casas "mais bem acabadas".

Há vários aspectos dessa "nova proposta" que merecem comentários.

No último dia 27 de março, foi realizada uma visita técnica à Comunidade da Vila Autódromo pelo grupo de técnicos (engenheiros, arquitetos, geógrafos) que se constituiu para apoiar a luta da comunidade e a atuação da Defensoria Pública. Durante a visita pôde-se constatar que a comunidade encontra-se abandonada pelo poder público e que, somente devido ao esforço das próprias familias, consegue-se manter padrões mínimos no funcionamento de alguns serviços públicos (coleta de lixo) e da insuficiente infraestrutura existente (manutenção da quadra de esportes, nivelamento do piso das ruas e vias de acesso, abertura de valas de drenagem ou para escoamento de esgoto, etc). Pôde-se constatar que a comunidade possui casas bem construidas e amplas, mas, também, possui algumas casas em condiçöes precárias ou ocupando áreas muito exíguas, e que necessitariam ser reconstruidas, havendo para isso terreno livre dentro da própria comunidade, próximo à área ocupada pelo Clube de Ultraleve.

Há vinte anos, pelo menos, a comunidade tem apresentado à prefeitura inúmeras reivindicações que envolvem a elaboração de um projeto de urbanização, com a participação direta da população e contando com o trabalho técnico de profissionais qualificados, e que resultem na implantação de infraestrutura urbana (redes de água, esgoto e drenagem; iluminação; pavimentação); implantação de equipamentos públicos (creche, escola, postos de saúde, centro cultural, área de lazer); e melhoria das próprias habitações, com apoio para a reconstrução daquelas que se encontram em estado precário. A prefeitura se propõe, agora, a reconhecer esses direitos da comunidade, relacionados à regularizaçăo e à urbanização, desde que a comunidade abra mão do direito conquistado de permanecer na área.

Já ficou demonstrado que não há qualquer razão técnica, objetiva, relacionada à realização dos Jogos Olímpicos, que justifique a transferência da comunidade para outra área. Mesmo assim, utilizando como pretexto a realização dos Jogos Olimpicos, a prefeitura promove 
uma verdadeira chantagem, ao acenar com a possibilidade de realizar os investimentos necessários para a melhoria das condições de vida da comunidade apenas se esta "aceitar" a proposta de remoção.

O "cálculo" feito pela prefeitura para demonstrar as "vantagens" dessa proposta, além de ignorar direitos conquistados, desconhece valores éticos e humanos, relaçōes sociais de solidariedade e laços afetivos, que não são construidos com cimento e areia, não entram nas planilhas de custos e não geram lucros para nenhuma empreiteira. A Vila Autódromo é uma comunidade que tem história, que tem sua origem em populações tradicionais de pescadores que foram os primeiros ocupantes dessa região; cujos laços foram ainda mais fortalecidos nas lutas contra todas as perseguições e ameaças que tem enfrentado; que está organizada, possuindo uma Associação de Moradores representativa e atuante; e cujos moradores construíram suas casas, pequenas ou grandes, como fruto de seu próprio esforço, durante muitos anos de suas vidas. A prefeitura pretende impor sua vontade à comunidade afirmando que estaria, assim, assegurando a "dignidade das famílias", mas, ao contrário dessa pretensão, a dignidade das familias dessa comunidade tem sua sustentação na solidariedade construída no dia-a-dia e na luta permanente pela afirmação de seus direitos.

A proposta da prefeitura desconhece todo esse processo, pretendendo arrancar as famílias do local onde construiram suas vidas e apagar a história da Comunidade da Vila Autódromo ${ }^{23}$, não tendo, portanto, nada de "humano". A comunidade além de ter o direito, já

${ }^{23}$ Entendemos que a sociedade ética é aquela que tece compromissos de longo prazo, com direitos inalienáveis e obrigações, planejamento e projetos para o futuro, compromissos do tipo "compartilhamento fraterno", reafirmando o direito de todos $e$ um seguro social contra os erros $e$ desventuras, porque a atribuição que nos dão de "favelados" "feios" $e$ "poluidores" não é uma questão de escolha, é antes o resultado da secessão. Somos lançados em um mundo de modernidade sem modernismo e a natureza dos "direitos humanos" é o direito a ter a diferença reconhecida e continuar diferente sem temor, todos em condições de igualdade.

E a injustiça que sentimos não é pela comparação de inveja, mas antes pela separação geográfica, cultural e econômica. Por que podem condomínios, shoppings e outros empreendimentos no entorno das Lagoas? Por que não há nenhum pescador morando próximo à orla das praias ou lagoas do RJ?

Observamos com amargura que não há estudo sobre os desempregados, os sem teto, os que moram nas ruas, enquanto uma elite global de negócios da indústria e do turismo está em uma zona protegida da cidade. É a sucessão dos bem-sucedidos, dos poderosos que atribuem generosos beneficios a si próprios a partir dos recursos da sociedade e que nos condena cada vez mais a uma miséria sem perspectiva e removidos, exilados, enquanto esta elite global vive num mundo acolchoado, em que tudo pode ser feito e refeito, num mundo onde não há lugar para duras realidades, como a pobreza, nem para $a$ indignidade, nem para a humilhação de ser incapaz de participar do "jogo do consumo". Somos a comunidade dos fracos e oprimidos.

Desejamos ser vistos como uma comunidade que não é descartável, que tem uma história, a história da laboriosa construção da nossa memória. E que cada passo que nos afasta da nossa casa, da nossa comunidade, vemos como mais uma catástrofe que empilha destroços sobre destroços, nos faz sentir como hebreus escravos no Egito, enquanto grupos imobiliários ou políticos privilegiados podem desfrutar de segurança existencial, luxo negado ao resto. 
manifestou seu desejo e sua determinação em permanecer na área e continuar lutando pela sua regularização definitiva e pela execução das obras de urbanização. Qualquer tentativa de impor uma proposta diferente dessa, por meio da manipulação de informaçōes, de intimidações e de chantagens, com roupagem nova ou antiga, representa uma violência contra a Comunidade da Vila Autódromo.

22. Uma questão final a ser desvendada é quanto ao nexo existente entre a "oportunidade" oferecida pelos Jogos Rio 2016 - "uma celebração que servirá ao mesmo tempo como fonte e acelerador de transformações, garantindo um legado sustentável para a cidade"24 - e a "oportunidade" para promover a remoção da Comunidade da Vila Autódromo.

Tem-se tomado cada vez mais freqüente as críticas quanto às consequências de longo prazo dos megaeventos esportivos sobre a vida das pessoas das cidades que os sediam, que desfazem o mito de que estes trazem apenas beneficios.

Recentemente, o estudo divulgado pela Relatora das Nações Unidas para o Direito à Moradia, Arquiteta e Urbanista Raquel Rolnik, alerta que "experiências passadas mostram que projetos de reurbanização adotados para a preparação de eventos resultaram em violações extensivas de direitos humanos, em especial o direito à moradia", mencionando, no caso da Rio 2016, a ameaça de expulsão dos moradores da Vila Autódromo.

Desenraizados, não haverá para nós dignidade, mérito e honra. Seguir outro caminho, sem alma, sem laços, sem identidade, sem companhia, sem vizinhos, obedecer aos decretos e as remoções, sem chance de escolha, nos leva a detestar a tudo e a todos, é desumano.

Destruir os laços comunitários que nos mantêm em uma comunidade natural, seria nos submeter pela coação, nua e sem sentido, à perda da dignidade, mérito e honra. E a imagem que vai nos restar é a de que o lugar de nossas casas não passa agora de pegadas, espaços vazios, lembranças apagadas pelos ventos, como já aconteceu no passado. E o lugar para onde iremos estará vazio de valor moral, de memória humana, de hospitalidade, repulsivo. Desapareceram o carteiro que nos conhece, a escola que nossos filhos estudam, a igreja que freqüentamos. Nestes lugares estarão os Condomínios, os Shoppings os Resorts, (Marapendi é testemunha) as cadeias de boutiques impessoais.

$O$ aconchego do nosso lar, nossos laços de sangue devem ser buscados diariamente, na linha de frente, na luta diária, reconstruindo sempre a nossa unidade através de um acordo e de um entendimento comum, mesmo que seja um único acordo disponível.

... Cada passo que nos afasta da nossa Comunidade será visto por nós como uma iniqüidade. $O$ balanço do passado nos indica que näo houve nenhuma açäo protetora a favor dos pescadores e do seu "habitat". A afirmação de que causamos poluição ambiental é proferida por pessoas privilegiadas social $e$ culturalmente, não falam por nós, mas por aqueles que consideram o mundo uma ostra de sua propriedade e mundo este que só está disponível para um grupo seleto de pessoas, que por sua vez não aceitam que podemos viver em uma época que pode ser ao mesmo tempo de emancipação, inclusão, autonomia, compromisso social e ambiental, nos tornando portadores de direitos, de sentimentos de segurança, compartilhamento, parceria, evitando que todos nós fiquemos catatônicos e frustrados em nossas ações, e dando às nossas vidas um sentido humano.

[ibidem]

${ }^{24}$ "Dossiê de Candidatura do Rio de Janeiro à Sede dos Jogos Olímpicos e Paraolímpicos de 2016"Conselho Executivo Rio 2016 / Volume I: "1. Visão, Legado e Comunicação". 
Segundo, ainda, o Relatório da ONU, "expulsões, encarecimento de moradia, falta de alternativas e pressão sobre os mais pobres, que acabam empurrados para as periferias, têm sido algumas das marcas mais características das Copas e Jogos Olimpicos". Para Raquel Rolnik "os benefícios econômicos desses eventos não são distribuidos de forma adequada à população e o legado é longe de ser positivo"25.

No documento que apresenta a candidatura da Rio 2016, por sua vez, é nítido o esforço em procura demonstrar que a realização dos Jogos, com a perspectiva de expressivos investimentos em infraestrutura, garantiriam um "legado sustentável para a cidade". Segundo o Dossiê da candidatura os jogos são, em si, "um fator positivo de mudança social": "Para os cariocas, os jogos transformarão a cidade. Surgirá uma nova infraestrutura urbana, novas iniciativas ambientais, fisicas e sociais, além de vantagens e oportunidades para todos". Sob o titulo "Inserção social: habitação, treinamento e emprego", são destacadas as quatro vilas (Vila de Mídia da Barra, Vila do Porto, Vila do Maracanã e Vila de Deodoro) que ficarão como "legado na área de habitação". ${ }^{26}$.

Uma análise um pouco mais detalhada de outras partes desse documento contribui para a identificar quais são essas "vantagens e oportunidades" e quem são os reais beneficiários do chamado "legado na área de habitação".

"Em combinação com a Vila Olimpica e Paraolimpica esses empreendimentos [as quatro vilas] oferecerão oportunidades de habitação, muito necessárias no Rio de Janeiro". "O projeto da Vila de Midia irá oferecer uma nova opção de moradia na Barra, uma região de alta demanda habitacional, ... uma opção de habitação acessivel para atender ao crescimento da procura por esse tipo de empreendimento" 27.

"A Vila Olimpica e Paraolímpica do Rio de Janeiro é um projeto residencial de alta qualidade na região que mais cresce na cidade, a Barra da Tijuca, o coração dos jogos ${ }^{228}$.

Nessa parte do documento encontramos informaçōes, que serão transcritas a seguir, que são bastante reveladoras da natureza da operação montada para viabilizar a Rio 2016. Essa operação envolve a participação das três esferas de governo, a utilização maciça de recursos públicos, uma generosa distribuição de "incentivos" e a garantia de "beneficios para o empreendedor" que, além de alugar as instalações por US $\$ 18,9$ milhões, poderá, ao final dispor, para comercialização, de "habitações em uma região de grande demanda":

\footnotetext{
25 “Olimpíada e Copa trazem prejuízo social" - O Estado de São Paulo - Jamil Chade - 5/3/2010

26 "Dossiê de Candidatura ..." - Conselho Executivo Rio 2016 / Volume I: "1. Visão, Legado e Comunicação"

27 "Dossiê de Candidatura ..." - Conselho Executivo Rio 2016 / Volume III: "14. Acomodações"

28 "Dossiê de Candidatura ..." - Conselho Executivo Rio 2016 / Volume III: "11. Vila Olímpica"
} 
Construtora Carvalho Hosken - Proprietária da área, construtora e integrante do Comitê Organizador Rio 2016

"O terreno da Vila Olimpica e Paraolimpica é de propriedade da Carvalho Hosken, uma grande construtora conhecida por seus projetos residenciais de atta qualidade. A Carvalho Hosken desenvolveu diversos empreendimentos bem sucedidos na Barra da Tijuca, incluindo projetos com conceitos de sustentabilidade ambiental. A empresa possui uma ampla experiência no mercado imobiliário local, além de comprovada capacidade de entregar grandes projetos.

A Carvalho Hosken, no papel de proprietária do terreno e construtora, irá assumir a responsabilidade pela construção da Vila Olímpica e Paraolimpica. A empresa já participa de um processo de estreita colaboraçäo com o Comitê de Candidatura Rio 2016, além de ter garantido a inclusäo de representantes do Comitê Organizador Rio 2016 no Grupo de Controle de Projeto da construção da Vila, com o objetivo de consolidar o desenvolvimento geral dos requisitos dos Jogos e de legado. ${ }^{279}$

\section{Financiamento e incentivos}

"O financiamento do projeto da Vila Olimpica e Paraolimpica está totalmente garantido pela Caixa Econômica Federal (CEF). Seguindo o modelo de financiamento bem sucedido no projeto da Vila Panamericana, a CEF garantiu a disponibilizaçăo de todos os recursos necessários para o empreendedor, com taxas de juros preferenciais.

... Além do atraente pacote financeiro do Governo Federal, uma série de outros incentivos será oferecida ao empreendedor, com o objetivo de garantir a viabilidade e a entrega. São eles:

- Análises e aprovações rápidas peto Departamento de Planejamento da Prefeitura do Rio

- Novas licenças de construçăo, dentro da legislaçăo de zoneamento em vigor na cidade e de acordo com O EIA

- A imediata construção de vias planejadas, senviços e recuperação ambiental do entomo

- Taxas de juros diferenciadas para os compradores.

Essas e outras iniciativas foram utilizadas no desenvolvimento da Vila Pan-americana, garantindo beneficios para o empreendedor, além de uma campanha de vendas de muito sucesso. 0 Comitê Organizador Rio 2016 irá alugar a Vila Olímpica e Paraolimpica do empreendedor. O custo acordado de locaçăo obedecerá a um teto de US\$18,9 milhöes. "3o

\section{Uso pós-Jogos}

"Após a realização dos Jogos, a Vila Olímpica e Paraolimpica se transformará em um empreendimento residencial baseado no modelo de sucesso estabelecido pelos Jogos Pan-americanos Rio 2007, fornecendo habitação em uma região de grande demanda. O projeto de legado está baseado em extensos estudos de viabilidade, fundamentados na grande procura por condomínios de alta qualidade na regiäo da Barra da Tijuca." 31

\footnotetext{
${ }^{29}$ ibidem

${ }^{30}$ ibidem

${ }^{31}$ ibidem
} 
A tabela a seguir apresenta o número de apartamentos previstos na Vila Olímpica e Vila de Mídia, número esse que demonstra que a Rio 2016 envolve uma operação imobiliária de grande porte em uma das áreas mais valorizadas da cidade:

\begin{tabular}{|l|c|c|c|c|}
\hline \multirow{2}{*}{ Instalação } & \multicolumn{4}{|c|}{$N^{\circ}$ de Apartamentos } \\
\cline { 2 - 5 } & 2 Quartos & 3 Quartos & 4 Quartos & Total \\
\hline Vila Olímpica & 7.884 & 1.649 & & 9.533 \\
\hline Vila de Midia & & 936 & 1.512 & 2.448 \\
\hline Total & 7.884 & 2.585 & 1.512 & 11.981 \\
\hline
\end{tabular}

Fonte: "Dossiê de Candidatura do Rio de Janeiro à Sede dos Jogos Olimpicos e Paraolimpicos de $2016^{n}$ - Conselho Executivo Rio 2016 / Volume Ii: "11. Vila Olimpica" / Volume III: "14. Acomodaçöes"

Considerando a dupla condição da Carvalho Hosken de proprietária do terreno e construtora e, além disso, a sua "estreita colaboração com o Comitê de Candidatura Rio 2016", o que inclui a participação de seus representantes no "Comitê Organizador Rio 2016", só podemos concluir que essa empresa usufrui de condições extremamente privilegiadas na estruturação da Rio 2016, sendo, na verdade, uma das grandes beneficiárias, senão a maior, do chamado "legado".

Não há dúvidas de que, essa empresa - conhecida não somente por sua "experiência", mas, também, por ser um dos principais agentes da especulação imobiliária no Rio de Janeiro e um dos três grandes proprietários de terras na Região da Barra da Tijuca - é a principal interessada na remoção da Comunidade da Vila Autódromo, o que, para ela, é uma forma de maximizar seus lucros.

A proposta de remoção de uma comunidade de baixa renda com o único propósito de favorecer poderosos interesses econômicos demonstra que a Rio 2016 está muito longe de garantir um "legado sustentável para a cidade" ou "vantagens e oportunidades para todos".

23. Como é sabido, o projeto que fundamentou a candidatura para os Jogos Olímpicos de 2016 não foi elaborado de forma democrática, não tendo contado com a participação da sociedade, sendo que as propostas dos locais de realização das competições e demais instalações, assim como as obras e infraestrutura previstas somente começaram a se tornar conhecidas a partir do anúncio da escolha do Rio de Janeiro.

Desde então, tendo conhecimento mais detalhado da proposta, iniciou-se a apresentação de diversos questionamentos por diferentes segmentos da sociedade, processo em que se insere o presente Relatório que trata, especificamente da proposta referente à Comunidade da Vila Autódromo. 
Para que nos aproximemos do objetivo enunciado de forma genérica, mas não confirmado pelas propostas, de garantir um legado sustentável para a cidade, o que deve representar beneficios para as comunidades pobres e estar associado, necessariamente, à diminuição das desigualdades sociais, será necessário um amplo processo de mobilização da sociedade carioca. A Comunidade da Vila Autódromo que, juntamente com outras comunidades, já deu exemplo na resistência contra as tentativas de remoção durante os Jogos Panamericanos - Rio 2007, já está mobilizada na luta em defesa de seus direitos e pela afirmação do direito à moradia e do direito à cidade.

Rio de Janeiro, 13 de maio de 2010

Canagé Vilhena - Arquiteto e Urbanista

Jorge Luís Borges - Geógrafo

Marcos de Faria Asevedo - Arquiteto e Urbanista

Maurício Campos dos Santos - Engenheiro Civil e Mecânico

Valéria Barbalho - Engenheira Civil 


\section{Anexo 2}

Gatos com compensação com expropriação da Vila Autódromo.

\begin{tabular}{|c|c|c|c|}
\hline DATA & $\begin{array}{l}\frac{\text { VALORES }}{\text { DAS }} \\
\text { INDENIZAÇÕES }\end{array}$ & $\begin{array}{c}\frac{\text { QUANTIDADE }}{\text { DE }} \\
\text { DESAPROPRIAÇÕES }\end{array}$ & $\begin{array}{l}\frac{\text { VALOR }}{\frac{\text { MÉDIO }}{\text { DA }}} \\
\text { INDENIZACÃO }\end{array}$ \\
\hline nov/14 & $\begin{array}{l}\mathrm{R} \$ \\
5.120 .388,00\end{array}$ & 5 & $\begin{array}{l}\mathrm{R} \$ \\
1.024 .077,60\end{array}$ \\
\hline $\mathrm{dez} / 14$ & $\begin{array}{l}\mathrm{R} \$ \\
38.712 .929,46\end{array}$ & 41 & $\begin{array}{l}\mathrm{R} \$ \\
944.217,79\end{array}$ \\
\hline $\begin{array}{c}\text { TOTAL DE } \\
2014\end{array}$ & $\begin{array}{l}R \$ \\
43.833 .317,46\end{array}$ & 46 & $\begin{array}{l}R \$ \\
952.898,21\end{array}$ \\
\hline $\mathrm{fev} / 15$ & $\begin{array}{l}\mathrm{R} \$ \\
18.584 .499,90\end{array}$ & 21 & $\begin{array}{l}\mathrm{R} \$ \\
884.976,19\end{array}$ \\
\hline mar/15 & $\begin{array}{l}\mathrm{R} \$ \\
3.968 .669,09 \\
\end{array}$ & 6 & $\begin{array}{l}\mathrm{R} \$ \\
661.444,85\end{array}$ \\
\hline$a b r / 15$ & $\begin{array}{l}\mathrm{R} \$ \\
24.136 .347,86\end{array}$ & 35 & $\begin{array}{l}\mathrm{R} \$ \\
689.609,94\end{array}$ \\
\hline mai/15 & $\begin{array}{l}\mathrm{R} \$ \\
4.490 .394,95\end{array}$ & 8 & $\begin{array}{l}\mathrm{R} \$ \\
561.299,37\end{array}$ \\
\hline $\begin{array}{c}\text { TOTAL DE } \\
2015\end{array}$ & $\begin{array}{l}R \$ \\
51.179 .911,80\end{array}$ & 70 & $\begin{array}{l}R \$ \\
731.141,60\end{array}$ \\
\hline $\begin{array}{l}\text { TOTAL } \\
\text { GERAL }\end{array}$ & $\begin{array}{l}R \$ \\
95.013 .229,26\end{array}$ & 116 & $\begin{array}{l}R \$ \\
819.079,56\end{array}$ \\
\hline
\end{tabular}

FONTE: OBTIDO COM A CÂMARA MUNICIPAL DO ESTADO DO RIO DE JANEIRO. GABINETE DA VEREADORA TERESA BERGHER, ELABORADA UTILIZANDO FONTES :FINCON e DIÁRIO OFICIAL DO MUNICÍPIO DO RIO DE JANEIR 